
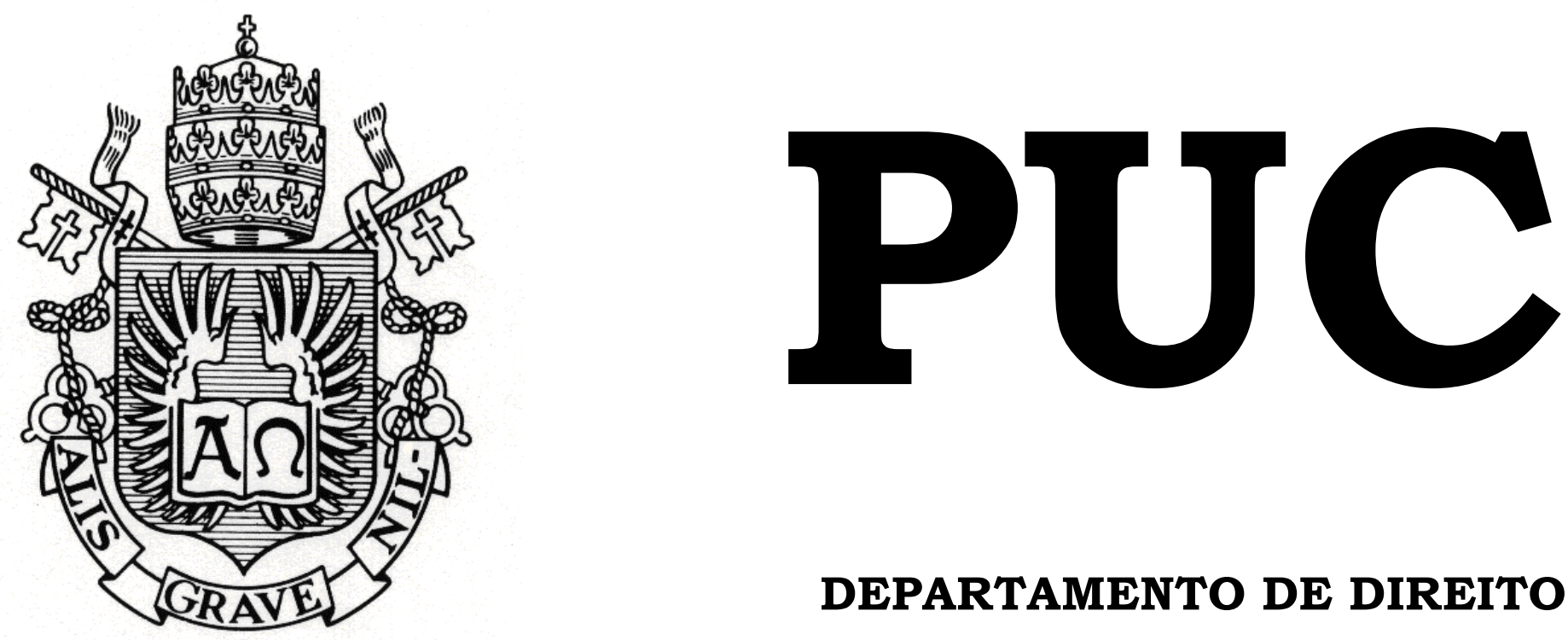

DEPARTAMENTO DE DIREITO

O PROJETO DE ÉTICA MUNDIAL DE HANS KÜNG por

JULIANA LUDMER

ORIENTADOR: MARCELLO CIOTOLA

2014.2

PONTIFÍCIA UNIVERSIDADE CATÓLICA DO RIO DE JANEIRO

RUA MARQUÊS DE SÃO VICENTE, 225 - CEP 22453-900

RIO DE JANEIRO - BRASIL 


\title{
O PROJETO DE ÉTICA MUNDIAL DE HANS KÜNG
}

\author{
por \\ JULIANA LUDMER
}

Monografia

apresentada

ao

Departamento de Direito da Pontificia Universidade Católica do Rio de Janeiro (PUC-Rio) para a obtenção do Título de Bacharel em Direito.

Orientador(a): Marcello Ciotola 
Ao professor e hispanista Marcello Ciotola;

Ao meu herói, Julio Ludemir;

À minha inspiração, Anna Beatriz;

Ao meu exemplo de vida, Zé Almino;

À minha generosa e brilhante avó, Anna Maria;

Ao meu amor, Rafael de Freitas. 


\section{Agradecimentos}

Ao meu pai, Julio Ludemir; à minha mãe, Anna Beatriz; ao meu padrasto, Zé Almino; à minha avó, Anna Maria; ao meu irmão, Rodrigo Sack; e ao meu anjo protetor, Cristiana Quirino, por todo o apoio, amor e carinho - não apenas durante a elaboração desta monografia, mas também ao longo do árduo processo de elaboração de mim mesma. A eles, devo tudo.

Ao professor, compositor, hispanista e amigo, Marcello Ciotola, que há cinco anos me orienta em pesquisas de filosofia do direito. Graças a ele, fiel seguidor da moral kantiana, interessei-me pelo estudo da ética. Graças a ele, deslumbrei-me pela Academia. Graças a ele, comecei a questionar criticamente o plano do ser. Ao Marcello, não apenas sou grata pela orientação deste trabalho monográfico, como também devo toda a minha formação acadêmica.

Aos professores da Pontifícia Universidade Católica do Rio de Janeiro. Sem os ensinamentos, jurídicos e não jurídicos, gentilmente compartilhados por eles, de nada valeria a graduação.

A todos os amigos que me acompanharam nestes cinco anos de bacharelato. Em especial, agradeço aos integrantes do movimento ContraCorrente, que não apenas me ajudaram a compreender o mundo jurídico sob diferentes perspectivas, como contribuíram para meu crescimento pessoal.

A Rafael Magalhães Florence, Pedro Luiz Papi de Moraes, Alexandre José Ribeiro Bandeira de Mello, Aroldo Moog e aos demais integrantes da equipe do PMKA Advogados, que me inspiram diariamente;

Ao meu amor, Rafael de Freitas, a quem devo minha felicidade, meu sorriso, minha sanidade e meu coração. 


\section{Resumo}

Hans Küng, filósofo e teólogo suíço, após se dedicar à análise crítica dos problemas que acometem a atual ordem pluralista global, conclui que a sobrevivência da humanidade depende da adoção, em âmbito mundial, de uma ética capaz de assegurar a convivência pacífica entre diferentes culturas, nações e religiões. Dessa forma, em 1990, o autor, por meio da obra Projekt Weltethos, apresenta o projeto de ética mundial que, a seu ver, possibilitará a paz no mundo plural e globalizado dos tempos atuais. A proposta do autor consiste em uma ética prescritiva, formada por valores compartilhados por todos os indivíduos - ética esta que poderia ser exigida de qualquer pessoa, independentemente do cenário cultural em que esteja inserida. Estes valores, por sua vez, deverão ser definidos por meio de amplo e constante diálogo intercultural. No presente trabalho, nos propomos a analisar o projeto de ética mundial de Hans Küng, a fim de esclarecer suas particularidades, que o diferenciam das demais propostas éticas, tais como a proposta rawlsiana, a ética discursiva construtivista habermasiana e a moral "fina" walzeriana.

Palavras-chave: projeto de ética mundial - Hans Küng - ethos - paz diálogo intercultural - valores compartilhados - globalização - pluralismo. 


\section{O projeto de Ética Mundial de Hans Küng}

\section{Sumário}



2 Do contexto no qual se evidencia a necessidade de uma ética mundial ...................... 10

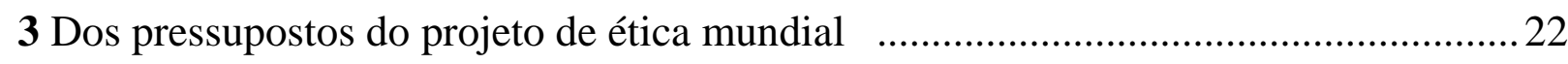

3.1 Da viabilidade de um diálogo intercultural ……….....................................23

3.2 Da existência de um consenso global de princípios éticos .................................27

3.3 Da possibilidade de extrair, de um diálogo intercultural, uma ética prescritiva



4 Dos protagonistas do projeto de ética mundial ............................................................ 34

4.1 Dos religiosos na busca pelo ethos mundial ......................................................... 34

4.2. Dos políticos na busca pelo ethos mundial....................................................... 41

4.3 Dos economistas na busca pelo ethos mundial................................................... 49

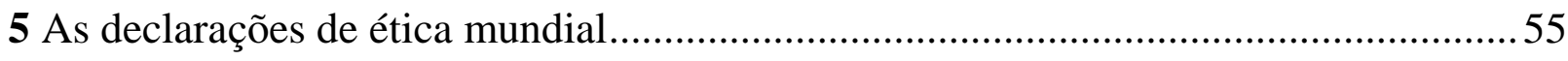

5.1 A Declaração do Parlamento das Religiões do Mundo ........................................56

5.2. A Declaração Universal das Responsabilidades Humanas................................. 72



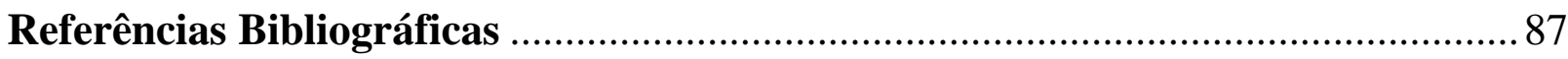




\section{Lista de abreviações}

EUA - Estados Unidos da América

INC. - Incorporation

INSEAD - Institut Européen d'Administration des Affaires

JP - Justice of the Peace

KCSG - Papal Knight Commander of the Order of Saint Gregory the Great

ONU - Organização das Nações Unidas

OStJ - Order of Saint John of Jerusalem

UNESCO - Organização das Nações Unidas para a Educação, a Ciência e a Cultura

URSS - União das Repúblicas Socialistas Soviéticas 


\section{Introdução}

Hans Küng, reconhecido filósofo e teólogo suíço formado pela Pontífícia Universidade Gregoriana ${ }^{1}$, após se dedicar à análise crítica dos problemas mundiais que acometem a ordem global atual ${ }^{2}$, conclui que a sobrevivência da humanidade depende da adoção, em âmbito global, de uma ética mundial capaz de assegurar a convivência pacífica entre diferentes culturas, nações e religiões. ${ }^{3}$

Desta forma, depois de intenso processo de pesquisa teóricohermenêutica ${ }^{4}$, em 1990, por meio da publicação da obra Projekt Weltethos $^{5}$, o autor propõe-se a apresentar um projeto de ética mundial capaz de assegurar a paz mundial no mundo pluralista e globalizado dos tempos atuais. $^{6}$

Sustenta Küng a ideia de que, para alcançar seu objetivo unificador, esta ética mundial deve ser composta por princípios éticos compartilhados por todos os indivíduos, independentemente do ambiente cultural em que convivem, no propósito de formar a base mais reduzida possível para a convivência humana e o agir comum, proporcionando uma ordem mundial pacífica. $^{7}$

\footnotetext{
${ }^{1}$ Para mais informações sobre a formação de Hans Küng, conferir KÜNG, Hans. Libertad Conquistada - Memorias. 4. ed. Madrid: Editorial Trotta, 2007. Na obra HOEREN, Jürgen; KÜNG, Hans. Para que um Ethos Mundial? Religião e ética em tempos de globalização conversando com Jürgen Hoeren. São Paulo: Edições Loyola, 2005, Küng também explica de forma detalhada como surgiu seu interesse pelo diálogo entre as religiões mundiais, intensificado a partir de 1979, após ter sido cassada, pelo Papa João Paulo II, sua autorização canônica para lecionar teologia em instituição superior católica, sob a alegação de ter questionado a infalibilidade papal. Nesta época, Küng havia publicado as obras "A Igreja", "Infalivel?", "Ser cristão", "Deus Existe?" e "Vida Eterna?" (HOEREN, Jürgen; KÜNG, Hans. Para que um Ethos Mundial? Religião e ética em tempos de globalização - conversando com Jürgen Hoeren. São Paulo: Edições Loyola, 2005. p. 18-19).

${ }^{2}$ KÜNG, Hans. Projeto de Ética Mundial - Uma moral ecumênica em vista da sobrevivência humana. 4. ed. São Paulo: Paulinas, 2003. p. 16-54.

${ }^{3}$ KÜNG, Hans. Projeto de Ética Mundial - Uma moral ecumênica em vista da sobrevivência humana. 4. ed. São Paulo: Paulinas, 2003. p. 54-75.

${ }^{4}$ KÜNG, Hans. Projeto de Ética Mundial - Uma moral ecumênica em vista da sobrevivência humana. 4. ed. São Paulo: Paulinas, 2003. p. 7.

${ }^{5}$ Em sua tradução para o português, Projekt Weltethos ganhou o título Projeto de Ética Mundial Uma moral ecumênica em vista da sobrevivência humana.

${ }^{6}$ KÜNG, Hans. Projeto de Ética Mundial - Uma moral ecumênica em vista da sobrevivência humana. 4. ed. São Paulo: Paulinas, 2003. p. 9.

${ }^{7}$ KÜNG, Hans. Projeto de Ética Mundial - Uma moral ecumênica em vista da sobrevivência humana. 4. ed. São Paulo: Paulinas, 2003. p. 54-75.
} 
A ética mundial proposta por Hans Küng, portanto, "não subentende uma nova ideologia mundial, nem tampouco uma religião mundial única para além de todas as religiões" ${ }^{8}$, mas traduz-se em uma ética básica formada por "um consenso fundamental quanto a valores obrigatórios vigentes, parâmetros inamovíveis e atitudes pessoais básicas". 9

Para tanto, assevera Küng que o conteúdo da ética mundial precisa ser definido por meio de um processo de constante diálogo intercultural e inter-religioso, ${ }^{10}$ no qual todos os interlocutores devem ter igual direito a voz - diálogo este que, vale destacar, já teria sido iniciado por meio de encontros internacionais promovidos ao longo do século $\mathrm{XX}$, nos quais foram assinados documentos como: a) A Declaração do Parlamento das Religiões do Mundo, solenemente proclamada em 4 de setembro de 1993, cujo anteprojeto Küng elaborou; b) A Declaração Universal das Responsabilidades Humanas, de $1^{\circ}$ de setembro de 1997, da qual Hans Küng foi o conselheiro acadêmico. ${ }^{11}$

$\mathrm{Na}$ presente monografia, analisaremos o projeto de ética mundial de Hans Küng, a fim de compreender suas particularidades, que o diferenciam das demais propostas éticas, tais como a proposta rawlsiana, a ética discursiva construtivista habermasiana e a moral "fina" walzeriana.

Com este intuito, no primeiro capítulo deste trabalho abordaremos o contexto mundial no qual se torna evidente, para Hans Küng, a necessidade

\footnotetext{
${ }^{8}$ Trecho extraído do item I da Declaração do Parlamento das Religiões do Mundo, solenemente proclamada em 4 de setembro de 1993. Esta declaração foi assinada pela maioria dos quase duzentos delegados das religiões mundiais que participaram do Parlamento das Religiões do Mundo, ocorrido no centenário do primeiro Parlamento Mundial das Religiões, em Chicago, em 1893. O Parlamento das Religiões do Mundo de 1993 (com a participação de 6.500 pessoas) ocorreu entre 28 de agosto e 4 de setembro de 1993 em Chicago. O processo de elaboração desta Declaração, seu conteúdo e signatários serão abordados de forma detalhada no capítulo "Do contexto no qual evidencia-se a necessidade de uma ética mundial" e no capítulo "As declarações de ética mundial" deste trabalho.

${ }^{9}$ Trecho extraído do item I da Declaração do Parlamento das Religiões do Mundo, solenemente proclamada em 4 de setembro de 1993. Para maiores informações sobre o processo de elaboração desta Declaração, seu conteúdo e signatários, conferir os capítulos "Do contexto no qual evidencia-se a necessidade de uma ética mundial" e "As declarações de ética mundial" deste trabalho.

${ }^{10}$ KÜNG, Hans. Projeto de Ética Mundial - Uma moral ecumênica em vista da sobrevivência humana. 4. ed. São Paulo: Paulinas, 2003. p. 58.

${ }^{11}$ HOEREN, Jürgen; KÜNG, Hans. Para que um Ethos Mundial? Religião e ética em tempos de globalização - conversando com Jürgen Hoeren. São Paulo: Edições Loyola, 2005, p. 29.
} 
de uma ética mundial. Além disso, apresentaremos os argumentos sustentados pelo autor para comprovar que a sobrevivência humana depende da adoção de novos parâmetros éticos, e demonstraremos a contribuição de Küng para o renascimento do processo de busca por uma ética mínima comum à sociedade mundial.

No segundo capítulo analisaremos, com a intenção de compreender a lógica interna do pensamento do autor, os três pressupostos de que se vale Küng ao elaborar o projeto de ética mundial: a) a viabilidade de um diálogo intercultural; b) a existência de um consenso global em relação aos princípios éticos; c) a possibilidade de extrair, de um diálogo intercultural, uma ética prescritiva universal. Também exporemos, nesse capítulo, os argumentos utilizados por Küng para comprovar a correção destas premissas.

No terceiro capítulo, abordaremos a visão de Küng sobre quem deve protagonizar este processo de busca pela ética mundial da humanidade, e os motivos pelos quais estes protagonistas precisam se comprometer com o projeto de Küng.

No quarto capítulo, analisaremos a metodologia e o conteúdo da Declaração do Parlamento das Religiões do Mundo e da Declaração Universal das Responsabilidades Humanas, as quais, para Küng, podem ser traduzidas como tentativas produtivas de mapeamento do ethos mundial da humanidade. $^{12}$

Por fim, no último capítulo, com base nas conclusões extraídas ao longo do processo de elaboração do presente trabalho, relacionaremos os principais elementos do projeto de ética mundial de Hans Küng, a fim de mostrar, de forma sintetizada, a essência do projeto de ethos mundial defendido pelo autor.

\footnotetext{
${ }^{12}$ HOEREN, Jürgen; KÜNG, Hans. Para que um Ethos Mundial? Religião e ética em tempos de globalização - conversando com Jürgen Hoeren. São Paulo: Edições Loyola, 2005, p. 29.
} 


\section{Do contexto no qual se evidencia a necessidade de uma ética mundial}

Hans Küng publicou sua primeira ${ }^{13}$ obra sobre "ética ${ }^{14}$ mundial", denominada Projekt Weltethos, em 1990, pouco depois de participar do simpósio promovido pela UNESCO em 1989, na cidade de Paris, sobre o tema "Nenhuma Paz Mundial sem Paz entre as Religiões", ${ }^{15}$ e do Fórum Econômico Mundial, realizado em 1990, em Davos. ${ }^{16}$

A promoção desses dois eventos era reflexo do ressurgimento da discussão, em âmbito global, a respeito da necessidade da adoção de medidas com vistas ao estímulo da convivência pacífica dos povos integrantes da ordem mundial. Tal discussão, por sua vez, era fruto da percepção de que,

[...] depois de duas guerras mundiais e após o fim da Guerra Fria, depois do colapso do fascismo e do nazismo e após o abalo do comunismo e do colonialismo, a humanidade [...] hoje em dia, disporia de recursos econômicos, culturais e espirituais suficientes para dar início a uma ordem mundial melhor. Contudo, antigas tensões étnicas, nacionais, sociais, econômicas e religiosas ameaçam a construção pacífica de um mundo melhor. ${ }^{17}$

\footnotetext{
${ }^{13}$ Hans Küng publicou diversas obras sobre o tema "ética mundial", tais como: a) Uma Ética Global para a Política e a Economia Mundiais; b) Para que um Ethos Mundial? Religião e ética em tempos de globalização - conversando com Jürgen Hoeren; c) Reivindicación de una Ética Mundial; d) Uma ética mundial e responsabilidades globais - duas declarações, dentre outras.

${ }^{14} \mathrm{O}$ autor esclarece, na obra Uma Ética Global para a Política e a Economia Mundiais, que o termo "ética" na expressão "ética mundial" é utilizado no sentido de "ethos", ou seja, pretende significar a atitude moral básica de uma pessoa ou de um grupo (KÜNG, Hans. Uma Ética Global para a Política e a Economia Mundiais. Petrópolis: Editora Vozes, 1999. p. 169). Esta questão terminológica também é elucidada na obra HOEREN, Jürgen; KÜNG, Hans. Para que um Ethos Mundial? Religião e ética em tempos de globalização - conversando com Jürgen Hoeren. São Paulo: Edições Loyola, 2005. p. 26.

${ }^{15}$ Hans Küng foi autor do artigo básico desse colóquio, do qual participaram Masao Abe (Kyoto), na qualidade de representante do budismo; Mohammed Arkoun (Paris), na qualidade de representante do islamismo; Eugene B. Borowitz (Nova Iorque), na qualidade de representante do judaísmo; Claude Geffré (Paris), na qualidade de representante do cristianismo; Liu Shu-hsien (Hong Kong), na qualidade de representante da religião chinesa; Bithika Mukerji (Benares), na qualidade de representante do hinduísmo; e Karl-Josef Partsch (Bonn), cuja função era discutir a questão sob a perspectiva do direito internacional (KÜNG, Hans; SCHMIDT, Helmut. Uma ética mundial e responsabilidades globais - duas declarações. São Paulo: Loyola, 2001. p. 52).

${ }^{16}$ Informações extraídas da obra KÜNG, Hans; SCHMIDT, Helmut. Uma ética mundial $e$ responsabilidades globais - duas declarações. São Paulo: Loyola, 2001. p. 93.

17 Trecho extraído do item I da Declaração do Parlamento das Religiões do Mundo, solenemente proclamada em 4 de setembro de 1993. Esta declaração foi assinada pela maioria dos quase duzentos delegados das religiões mundiais que participaram do Parlamento das Religiões do Mundo, ocorrido no centenário do primeiro Parlamento Mundial das Religiões, em Chicago, em 1893. O processo de elaboração dessa Declaração, seu conteúdo e signatários serão abordados de
} 
Desde o fim da Primeira Guerra Mundial, debate-se sobre qual o melhor caminho para a manutenção de uma ordem mundial pacífica. Em 1918, explica Küng, deu-se início à trajetória mundial em direção à pósmodernidade $^{18}$ - até o presente momento, segundo o autor, ainda não alcançada. ${ }^{19} \mathrm{O}$ início desse processo de superação da modernidade pode ser constatado por meio das seguintes observações, as quais, segundo Küng, apontavam produtiva mudança rumo a uma constelação geral pósmoderna: ${ }^{20}$ a) em 1918, tornou-se evidente que o domínio mundial das potências europeias estava fadado a ser substituído por um policentrismo; b) já naquela ocasião tinha-se ciência de que nova guerra mundial, com os avanços tecnológicos e científicos, poderia arruinar por completo a Europa; c) crescia um movimento pacifista que defendia o desarmamento total e a paz mundial; d) as críticas à civilização e à desenfreada destruição do meio ambiente tornavam-se massivas; e) naquele momento, surgia, por meio de conferências e alianças internacionais, o movimento ecumênico que desembocou na criação do Conselho Mundial de Igrejas e levou ao Concílio Vaticano II.

forma detalhada no capítulo "Do contexto no qual se evidencia a necessidade de uma ética mundial", e no capítulo "As declarações de ética mundial" deste trabalho.

${ }^{18}$ De acordo com Küng, "o paradigma político da Era Moderna foi iniciado no século XVII pela França de Richelieu: política sem inibições morais, no interesse do Estado nacional; moderado no século XVIII pela Inglaterra: a tendência hegemônica dos estados nacionais contrabalançada pelo princípio do equilíbrio das potências; estabilizado na primeira metade do século XIX (após um período de hegemonia francesa sob Napoleão) pela Áustria sob Metternich: um "concerto" de orientação anti-revolucionária das grandes potências européias; abalado na segunda metade do século XIX pela Prússia-Alemanha sob Bismarck, e uma nova fria política do "real" interesse nacional; e levado até o absurdo pela Primeira Guerra Mundial provocada sobretudo pela Alemanha, mas visada também pelas outras grandes potências" (KÜNG, Hans. Uma Ética Global para a Política e a Economia Mundiais. Petrópolis: Editora Vozes, 1999. p. 66-67). Para um exame circunstanciado do conceito de modernidade nas suas várias acepções sob o prisma de um historiador, consultar LE GOFF, Jacques. História e memória. Campinas: Unicamp, 1990. p. 92109.

${ }^{19}$ Küng esclarece, na obra Projeto de Ética Mundial - Uma moral ecumênica em vista da sobrevivência humana, que o termo "pós-modernidade" é utilizado por ele no sentido da "história mundial", isto é, como sinônimo de um processo de superação da modernidade que se iniciou - e ainda não foi concluído - com a irrupção fundamental da modernidade, decorrente do "desmoronamento da sociedade burguesa e o mundo eurocentrista por ocasião da Primeira Guerra Mundial" (KÜNG, Hans. Projeto de Ética Mundial - Uma moral ecumênica em vista da sobrevivência humana. 4. ed. São Paulo: Paulinas, 2003. p. 18).

${ }^{20}$ Tais informações podem ser extraídas da obra KÜNG, Hans. Projeto de Ética Mundial - Uma moral ecumênica em vista da sobrevivência humana. 4. ed. São Paulo: Paulinas, 2003. p. 20. 
A ascendência de uma nova ordem mundial naquela época, porém, foi prejudicada em razão de "contra-movimentos reacionários e totalitaristas", ${ }^{21}$ tais como: ${ }^{22}$ a) o fascismo na Itália, na Espanha e em Portugal, e o nacionalismo na Alemanha, que provocou a Segunda Guerra Mundial e a perseguição aos judeus. Estes movimentos, explica Hans Küng, "apesar de sua fachada moderna e organizada, foram movimentos nacionalistas de cunho romântico-reacionário que, na verdade, frearam o desenvolvimento de uma ordem mundial pacífica"; ${ }^{23}$ b) "o militarismo no Japão, que surgiu na mesma época e que oprimiu toda a oposição interna"; c) o comunismo revolucionário, que, apesar de ter nascido como um movimento democrático promissor e em prol das massas, em 1918 foi deturpado por Lênin e transformado em uma "ditadura do partido comunista sobre o povo e até mesmo sobre o proletariado". ${ }^{24}$

Essas correntes que, a seu modo, pretendiam superar a crise pósPrimeira Guerra Mundial ironicamente contribuíram para a eclosão da Segunda Guerra Mundial, derrogando as esperanças de uma ordem global pacífica e estável. Após a Segunda Guerra Mundial, o movimento ambientalista, o movimento pacifista e o movimento feminista "vieram novamente à tona, irrompendo com toda a força". ${ }^{25}$ No entanto, complementa Küng, o desejo por uma ordem global pacífica foi mais uma vez obstado pelo surgimento de "um antagonismo político, econômico e militar de duas superpotências (Estados Unidos e União Soviética)". ${ }^{26}$

\footnotetext{
${ }^{21}$ KÜNG, Hans. Projeto de Ética Mundial - Uma moral ecumênica em vista da sobrevivência humana. 4. ed. São Paulo: Paulinas, 2003. p. 21.

${ }^{22}$ Estas informações podem ser extraídas de KÜNG, Hans. Projeto de Ética Mundial - Uma moral ecumênica em vista da sobrevivência humana. 4. ed. São Paulo: Paulinas, 2003. p. 22.

${ }^{23}$ KÜNG, Hans. Projeto de Ética Mundial - Uma moral ecumênica em vista da sobrevivência humana. 4. ed. São Paulo: Paulinas, 2003. p. 16.

${ }^{24}$ KÜNG, Hans. Projeto de Ética Mundial - Uma moral ecumênica em vista da sobrevivência humana. 4. ed. São Paulo: Paulinas, 2003. p. 23.

${ }^{25}$ HOEREN, Jürgen; KÜNG, Hans. Para que um Ethos Mundial? Religião e ética em tempos de globalização - conversando com Jürgen Hoeren. São Paulo: Edições Loyola, 2005. p. 153.

${ }^{26}$ KÜNG, Hans. Projeto de Ética Mundial - Uma moral ecumênica em vista da sobrevivência humana. 4. ed. São Paulo: Paulinas, 2003. p. 23.
} 
No final do século $\mathrm{XX}$, as grandes ideologias modernas, que por tanto tempo funcionaram como "explicações científicas e totais e como semi-religiões", ${ }^{27}$ se depreciaram. Ao final da Guerra Fria, na opinião de Küng, não só a ideologia do desenvolvimento revolucionário do Leste soviético estava desgastada, como também a ideologia do desenvolvimento evolutivo-tecnológico do Ocidente encontrava-se em grave crise, ${ }^{28} \mathrm{em}$ razão de um vazio moral causado pela "destruição de toda e qualquer tradição, de um sentido de vida mais abrangente, de padrões éticos imprescindíveis, e falta de novos objetivos, junto com os prejuízos físicos daí decorrentes". ${ }^{29}$

Como consequência do vazio moral que acometia (e acomete) as sociedades, Küng observava que, mesmo superadas as duas grandes guerras mundiais, ainda estavam presentes no contexto global os principais problemas da modernidade, tais como excessivos gastos com armamento militar; tortura e assassinatos praticados por governos repressivos; endividamento cada vez maior dos países do Terceiro Mundo; ${ }^{30}$ perigosas tensões entre crentes e não crentes; constante ameaça de choque entre civilizações $^{31}$ (como exemplo, o autor cita a crescente beligerância entre a sociedade muçulmana e a sociedade ocidental); ${ }^{32}$ problemas ambientais ${ }^{33}$ conflitos religiosos. Essas variáveis, somadas, representavam, para o autor,

\footnotetext{
${ }^{27}$ KÜNG, Hans. Projeto de Ética Mundial - Uma moral ecumênica em vista da sobrevivência humana. 4. ed. São Paulo: Paulinas, 2003. p. 33.

${ }^{28}$ KÜNG, Hans. Projeto de Ética Mundial - Uma moral ecumênica em vista da sobrevivência humana. 4. ed. São Paulo: Paulinas, 2003. p. 33.

${ }^{29}$ KÜNG, Hans. Projeto de Ética Mundial - Uma moral ecumênica em vista da sobrevivência humana. 4. ed. São Paulo: Paulinas, 2003. p. 28.

${ }^{30}$ KÜNG, Hans. Projeto de Ética Mundial - Uma moral ecumênica em vista da sobrevivência humana. 4. ed. São Paulo: Paulinas, 2003. p. 16.

${ }^{31}$ De acordo com o que consta na obra HOEREN, Jürgen; KÜNG, Hans. Para que um Ethos Mundial? Religião e ética em tempos de globalização - conversando com Jürgen Hoeren, Küng abordou a problemática do possível choque de civilizações em 1984, "muito antes de Samuel P. Huntington chamar atenções gerais para si com o artigo "Clash of Civilizations"" (HOEREN, Jürgen; KÜNG, Hans. Para que um Ethos Mundial? Religião e ética em tempos de globalização conversando com Jürgen Hoeren. São Paulo: Edições Loyola, 2005. p. 19).

${ }^{32}$ KÜNG, Hans. Uma Ética Global para a Política e a Economia Mundiais. Petrópolis: Editora Vozes, 1999. p. 166.

${ }^{33}$ KÜNG, Hans. Projeto de Ética Mundial - Uma moral ecumênica em vista da sobrevivência humana. 4. ed. São Paulo: Paulinas, 2003. p.34
} 
grave perigo, pois sinalizavam que a sociedade do desenvolvimento corria risco de autodestruição, ${ }^{34}$ e as nações caminhavam para a ruína econômica, a desmontagem social e a catástrofe política. ${ }^{35}$ A sobrevivência humana, portanto, dependia de uma resposta para os problemas relatados.

De outro lado, reconhecia Küng que a "constelação mundial pósmoderna" ${ }^{36}$ estava marcada pela seguinte conjuntura: a) geopoliticamente, o eurocentrismo havia sido superado pelo policentrismo; b) em termos de política externa, a sociedade mundial podia ser classificada como póscolonialista e pós-imperialista; c) em termos econômicos, desenvolvia-se uma economia pós-capitalista e pós-socialista; d) em termos políticos e sociais, formava-se uma sociedade pós-industrial. ${ }^{37}$

Com base na análise do quadro exposto, o autor conclui pela necessidade da promoção de um processo de busca por uma ética mínima comum à sociedade mundial para servir como critério de agir a ser seguido pelos líderes políticos, a fim de garantir uma coesão entre todos os países e religiões e, consequentemente, a paz mundial. O conteúdo deste ethos

\footnotetext{
${ }^{34}$ KÜNG, Hans. Projeto de Ética Mundial - Uma moral ecumênica em vista da sobrevivência humana. 4. ed. São Paulo: Paulinas, 2003. p. 34.

${ }^{35}$ KÜNG, Hans. Projeto de Ética Mundial - Uma moral ecumênica em vista da sobrevivência humana. 4. ed. São Paulo: Paulinas, 2003. p. 54.

${ }^{36}$ Este termo é usado por Hans Küng na obra: KÜNG, Hans. Projeto de Ética Mundial - Uma moral ecumênica em vista da sobrevivência humana. 4. ed. São Paulo: Paulinas, 2003. p. 45. Para melhor compreensão do novo macroparadigma que a constelação geral pós-moderna representa, Küng indica a leitura do historiador KUHN, Thomas S. A estrutura das revoluções científicas. São Paulo, 1996 (KÜNG, Hans. Projeto de Ética Mundial - Uma moral ecumênica em vista da sobrevivência humana. 4. ed. São Paulo: Paulinas, 2003. p. 44).

${ }^{37}$ Para Küng, após a Segunda Guerra Mundial, o mundo presenciou uma segunda Revolução Industrial, que, nas palavras do autor, "fortaleceu e até substituiu o trabalho intelectual humano com o auxílio de máquinas (através de computadores e telecomunicações)" (KÜNG, Hans. Projeto de Ética Mundial - Uma moral ecumênica em vista da sobrevivência humana. 4. ed. São Paulo: Paulinas, 2003. p. 38). Esta revolução industrial, marcada por intensas invenções eletrônicas, técnica de miniaturas, digitalização, softwares, não desembocou em um tempo mais digno e humano, como pensavam os mais otimistas. De outro lado, também não causou o "declínio do Ocidente", como pensavam os utopistas pessimistas, tais como O. Spengler (SPENGLER, Oswald apud KÜNG, Hans. Uma Ética Global para a Política e a Economia Mundiais. Petrópolis: Editora Vozes, 1999. p. 41). Para KÜNG, a segunda Revolução Industrial trouxe irrupções inovadoras, que podem "facilitar a sobrevivência da humanidade" (OERTLI-CAJACOB, Innovation statt Regination apud KÜNG, Hans. Uma Ética Global para a Política e a Economia Mundiais. Petrópolis: Editora Vozes, 1999. p. 41), tais como a ecotécnica, que aprimorou processos de reciclagem e administração do lixo; o aperfeiçoamento da tecnologia de armazenamento de energia menos prejudicial ao meio ambiente; o descobrimento de novas matérias-primas biodegradáveis.
} 
mundial, o caminho para alcançá-lo e sua função serão abordados com mais profundidade nos capítulos seguintes.

Tal ethos mundial, de acordo com o autor, ${ }^{38}$ marcaria uma era de superação da modernidade,${ }^{39}$ na medida em que: a) afirmaria o que a modernidade tem de humano; b) negaria os limites desumanos da modernidade; c) transcenderia a modernidade para uma nova síntese, diferenciada, pluralista e holística; e por estes motivos garantiria a sobrevivência humana, na medida em que formaria um consenso fundamental sobre as convicções humanas integradoras.

Em 1992, pouco tempo depois da publicação do primeiro livro de Hans Küng sobre o tema "ética mundial", o Conselho responsável pela preparação do Segundo Parlamento das Religiões Mundiais, por meio de seu diretor executivo, Daniel Gómez-Ibañes, convidou ${ }^{40}$ Küng a elaborar "um projeto de uma declaração pelo Parlamento sobre uma ética mundial", ${ }^{41}$ a ser assinada por representantes de todas as religiões presentes no Segundo Parlamento das Religiões Mundiais, que deveria ocorrer em 1993, cem anos após o Primeiro Parlamento das Religiões Mundiais. ${ }^{42}$

\footnotetext{
${ }^{38}$ KÜNG, Hans. Projeto de Ética Mundial - Uma moral ecumênica em vista da sobrevivência humana. 4. ed. São Paulo: Paulinas, 2003. p. 51-53.

${ }^{39}$ Conferir a nota de rodapé $\mathrm{n}^{\circ} 08$ deste trabalho.

${ }^{40}$ De acordo com o que consta no livro KÜNG, Hans; SCHMIDT, Helmut. Uma ética mundial e responsabilidades globais - duas declarações. São Paulo: Loyola, 2001, em 1989 Küng já havia sido convidado, por Ron Kidd, administrador do Concílio das Religiões Mundiais, a traçar o primeiro esboço da declaração sobre uma ética comum para o Parlamento, em colaboração com uma equipe em Chicago. No entanto, o projeto, naquele momento, não foi levado adiante (KÜNG, Hans; SCHMIDT, Helmut. Uma ética mundial e responsabilidades globais - duas declarações. São Paulo: Loyola, 2001. p. 53).

${ }^{41}$ KÜNG, Hans; SCHMIDT, Helmut. Uma ética mundial e responsabilidades globais - duas declarações. São Paulo: Loyola, 2001. p. 55.

${ }^{42} \mathrm{O}$ Parlamento das Religiões Mundiais é uma organização internacional não governamental ecumênica e interreligiosa. O primeiro simpósio do Parlamento das Religiões Mundiais ocorreu em Chicago, entre 11 de setembro e 27 de setembro de 1893. Em 1988, foi formado o Conselho do Parlamento Mundial de Religiões, que preparou o congresso de 1993. Tais informações podem ser extraídas de KÜNG, Hans; SCHMIDT, Helmut. Uma ética mundial e responsabilidades globais duas declarações. São Paulo: Loyola, 2001, e dos seguintes endereços eletrônicos: $\langle\mathrm{http} / / /$ people.bu.edu/wwildman/bce/worldparliamentofreligions1893.htm〉. Acesso em: $20 \mathrm{de}$ agosto de 2014, às $09: 44 \mathrm{~h}$;

http://web.worldbank.org/WBSITE/EXTERNAL/EXTABOUTUS/PARTNERS/EXTDEVDIALO GUE/0,,contentMDK:20270092 menuPK:1477281 pagePK:64192523 piPK:64192458 theSiteP K:537298,00.html>. Acesso em: 20 de agosto de 2014, às 09:45h.
} 
O anteprojeto elaborado por Küng foi aprovado pela diretoria do Parlamento das Religiões Mundiais, em julho de 1993, sendo, após alguns poucos ajustes, levado à deliberação no Conselho do Segundo Parlamento das Religiões Mundiais, reunido em Chicago de 28 de agosto a 04 de setembro de 1993, evento que "contou com a participação de 6.500 pessoas de todas as religiões possíveis" ${ }^{43}$. Nesse encontro, após exaustivos debates, elaborou-se a Declaração para uma Ética Global do Parlamento das Religiões do Mundo $^{44}$, na qual se encontravam relacionados princípios éticos aceitáveis pelos partidários de todas as religiões. ${ }^{45}$

${ }^{43}$ KÜNG, Hans; SCHMIDT, Helmut. Uma ética mundial e responsabilidades globais - duas declarações. São Paulo: Loyola, 2001. p. 48.

${ }^{44}$ A Declaração foi assinada por representantes das seguintes religiões em Chicago: I) Bahai: Juana Conrad, Jacqueline Delahunt, Dr. Wilma Elis, Charles Nolley, R. Leilani Smith e Yael Wurmfeld; II) Brahma Kumaris: B.K. Jagdish Chander Hassija, B. K. Dadi Prakashmani; III) Budismo: Rev. Koshin Ogui, Sensei; III.1) Mahayana: Rev. Chung Ok Lee; III.2) Theravada: Dr. A.T. Ariyaratne, Preah Maha Grosanada, Ajahn Phra Maha Surasak Jivanando, Dr. Chatsumarn Kabilsingh, Luang Poh Panyananda, Ven. Achahn Dr Chuen Phangcham; Ven. Dr. Havanpola Ratanasara, Ven Dr. Mapalagama Wipulasara Maha Thero; III.3) Vajrayana: Sua Alteza o Décimo Quarto Dalai Lama; III.4) Zen: Prof. Masao Abe, Zen Master Seung Sahn, Rev. Samu Sunim; IV) Cristianismo: Blouke Carus, Dr Yvone Delk; IV.1) Anglicano: Rev. Marcus Braybooke, James Parks Morton; IV.2) Ortodoxo: Maria Svolos Gebhard; IV.3) Protestante: Dr. Thelma Adair, Martti Ahtisaari, Rev. Wasley Ariarajah, Dr. Gerald O. Barney; Dr. Nelvia M. Brady; Dr. David Breed, Rev. John Buchanan, Bispo R. Sheldon Dueker, Prof. Diana L. Eck, Dr. Leon D. Finney Jr, Dr. James A. Forbes Jr., Bispo Frederick C. James, Arcebispo Mikko Juva, Prof. James Nelson, Dr. David Ramage Jr., Robert Reneker, Rev. Dr. Synginan Rhee, Rev. Margareth Orr Thornas, Prof. Carl Friedrich von Weizsäcker, Prof. Henry Wilson; Rev. Addie Wyatt; IV.4) Rev. Thomas A. Baima, Cardeal Joseph Bernardin, Fr. Pierre-François de Béthune, Irmã Joan M. Chatfield MM, Rev. Theodore M. Herburgh CSC, Abade Timothy Kelly OSB, Jim Kenney, Prof. Hans Küng, Dolores Leakey, Irmã Joan Monica McGuire OP, Rev. Maximilian Mizzi, Dr. Robert Muller, Rev. Albert Nambiaparambil, Bispo Placido Rodriguez, Bispo Willy Romélius, Dorothy Savage, Irmão David Steind-Rast OSB, Irmão Wayne Teasdale; V) Religiões nativas: Sua Glória Imortal Bambi Baaba; V.1) Akuapi: Nana Apeadu; V.2) Yoruba: Sua Alteza Real Oseijeman Adefunmi I, Baba Metahocki Kofi Zannu; V.3) Americana Nativa: Archie Mosay, Burton Pretty on Top, Peter V. Catches; VI) Hinduísmo: Dr. M. Aram, Jayashree Athavale-Taiwarkar, Sua Alteza Swami Chidananda Saraswafi, Swami Chidananda Saraswafi Muniji, Swami Dayananda Saraswafi, Sadguru Sant Keshavadas, P.V. Krishnayya, Dr. Lakshmi Kumari, Amrish Mahajan, Dr. Krishna Reddy, Prof. V. Madhusudan Reddy, Swami Satchidananda, Sua Alteza Satguru Sivaya Subramuniyaswami, Sua Alteza Dr. Bala Siva Yogindra Maharaj; VI.1) Vedanta: Pravrajika Amalaprana, Irravrajika Prabuddhaprana, Pravnajika Vivekaprana; VI.2) Jainismo: Dr. Raslnnikant Gardi; VI.3) Digambar: Narenda P. Jain; VI.4) Swethambar: Sua Alteza Shri Atmanandji, Dipchand S. Gardi, Sua Excelência Dr. L.M. Singhvi, Sua Alteza Acharya Sushil Kumarji Maharaj; VII) Judaísmo: Helen Spector, Sir Sigmund Stenberg; VII.1) Conservador: Professor Susannah Heschel; VII.2) Reformado: Rabino Herbert Bronstein, Norma U. Levitt, Rabino A. James Rudin, Rabino Herman Schaalman, Dr. Howard a. Sulkin; VII.3) Ortodoxo: Prof. Ephraim Isaac; VIII) Islamismo: Tan Sri Dato' Seri Ahmad Sarji bin Abdul-Hamid, Dr. Qazi Ashfaq Ahmed, Hamid Ahmed, Mazar Ahmed, Hon. Louis Farrakhan, Dr. Hamid Abdul Hai, Mohammed A. Hai, Dr. Mohammad Hamidullah, Dr. Aziza al-Hibri, Dr. Asad Husain, Dato Dr. Haji Ismail bin Ibrahim, Dr. Irfan Ahinat Kilan, Qadir H. Khan, Dr. Abel Rahman Osman; VIII.1) Prof. Seyyed Hossein Nasr; VIII.2) Sunita: Imam Dawud Assad, Imam Warith Deen Mohammed, 
A partir do livro Projekt Weltethos e da Declaração para uma Ética Global do Parlamento das Religiões do Mundo, tornou-se claro que, "a despeito de todas as diferenças dogmáticas, certo consenso ético pode ser encontrado entre todas as religiões do mundo", ${ }^{46}$ o qual poderia "formar a base de uma ética mundial: um consenso básico mínimo a respeito de valores impositivos, critérios irrevogáveis e posições morais básicas, [...] possível de ser defendido e seguido por crentes e não crentes". ${ }^{47}$ Isto porque, mesmo "numa época em que tantas religiões estão emaranhadas em conflitos políticos e até mesmo em guerras sangrentas, representantes de uma variedade de religiões, grandes e pequenas, identificaram-se com essa Declaração, assinando-a como representantes dos 6.500 membros do Parlamento de toda religião possível, representando inúmeros crentes deste mundo". 48

Desde então, retomou-se em âmbito global o anseio por uma ética mundial - anseio este que já podia ser notado em pontuais iniciativas anteriores, tais como a promoção do Primeiro Parlamento das Religiões Mundiais, datado de 1893; a Declaração Universal dos Direitos Humanos, adotada pela Organização das Nações Unidas em 1948; e a declaração

Hon Syed Shahabuddin; IX) Neopaganismo: Rev. Baroness Cara-Marguerite-Drusilla, Rev. Deborah Ann Light, Lady Olivia Robertson; X) Sikhs: Sin Singh Sahbi Bhai Sahib Harabhakan Singh Khalsa Yogiji, Bhai Mohinder Singh, Dr. Mehevan Singh, Hardial Singh, Indarjit Singh, Singh Sahib Jathedar Manjit Singh, Dr Baiwant Singh Hansra; X.1) Taoísta: Chungliang Al Huang; XI) Teosofista: Radha Burnier; XII) Zoroatristas: Dastoor Dr. Kersey Antia, Dr. Homi Dhala, Dastoor Dr. Kaikhusroo Minocher JamaspAsa, Dastoor Jehangir Oshidari Rohinton Rivetna, Homi Taleyarkhan, Dastoor Kobad Zarolit, Dastoor Mehraban Zarthosty; XIII) Organizações inter-religiosas: Karl Berzolheimer, Dr. Daniel Gómez-Ibáñez, Ma Jaya Bhagavati, Peter Laurence, Dr. Karan Singh, John B. Taylor, Rev. Robert Traer, Dr. William D. Vendley. Estas informações foram extraídas de KÜNG, Hans; SCHMIDT, Helmut. Uma ética mundial e responsabilidades globais - duas declarações. São Paulo: Loyola, 2001. p. 10-44. Apesar de a obra em questão listar todos os que participaram da referida Declaração, é válido ressalvar que não foi esclarecido o critério utilizado para a seleção dos membros convidados a subscrever a Declaração.

${ }^{45}$ KÜNG, Hans; SCHMIDT, Helmut. Uma ética mundial e responsabilidades globais - duas declarações. São Paulo: Loyola, 2001. p. 59. O conteúdo dessa Declaração será abordado mais detalhadamente nos próximos capítulos deste trabalho.

${ }^{46}$ KÜNG, Hans; SCHMIDT, Helmut. Uma ética mundial e responsabilidades globais - duas declarações. São Paulo: Loyola, 2001. p. 93.

47 KÜNG, Hans; SCHMIDT, Helmut. Uma ética mundial e responsabilidades globais - duas declarações. São Paulo: Loyola, 2001. p. 93.

${ }^{48}$ KÜNG, Hans; SCHMIDT, Helmut. Uma ética mundial e responsabilidades globais - duas declarações. São Paulo: Loyola, 2001. p. 93. 
emitida pela Conferência Mundial das Religiões em favor da Paz, realizada em Kyoto em $1990 .^{49}$

A necessidade de uma ética mundial, segundo o autor, ${ }^{50}$ foi reconhecida internacionalmente em inúmeros momentos posteriores à promulgação da Declaração para uma Ética Global do Parlamento das Religiões do Mundo, tais como: a) no relatório "Nossa Vizinhança Global", produzido pela Comissão Geral da ONU, em 1995; b) no relatório "Nossa Diversidade Criativa", produzido pela Comissão Mundial sobre Cultura e Desenvolvimento, em 1995; c) no relatório final "Propostas para Orientação e Atividades Futuras", publicado pelo Projeto do Terceiro Milênio, em 1997; d) no press release do Fórum Econômico Mundial de 1997 (Davos, Suiça); e) nas recomendações finais do Projeto de Ética Universal da UNESCO de 1997; f) no relatório produzido na Sexta Conferência Indira Gandhi, em Delhi (1997), sobre Interdependências e Identidades num Mundo Pós-Colonial.

Em 1995, "graças à doação de alguns recursos financeiros pelo Conde K. K. von der Groeben, tornou-se possível a criação da Fundação de Ética Mundial, sediada em Tübingen, na qual atua uma equipe executiva e de pesquisa científica" ${ }^{51}$ sobre o tema. Em 1997, a InterAction Council,

\footnotetext{
${ }^{49}$ Hans Küng faz referência expressa a essa declaração como manifestação em favor de uma ética mundial em KÜNG, Hans. Projeto de Ética Mundial - Uma moral ecumênica em vista da sobrevivência humana. 4. ed. São Paulo: Paulinas, 2003. p. 111.

${ }^{50}$ KÜNG, Hans; SCHMIDT, Helmut. Uma ética mundial e responsabilidades globais-duas declarações. São Paulo: Loyola, 2001. p. 99-106.

${ }^{51}$ UNISINOS, Revista do Instituto Humanitas Unisinos, edição 240, 2007. p.3. Disponível em: <http://pt.scribd.com/doc/7991717/6/Hans-Kung-\%E2\%80\%93-Biografia>. Acesso em: 23 de agosto de 2014, às 22:15h. Ao longo do tempo, novos escritórios da Fundação Ética Mundial foram sendo inaugurados: na Suíça, em 1996; na República Tcheca, em 1999; na Holanda, no ano 2000; na Áustria, em 2001; no México e na Colômbia, em 2006. E agora em 2008, no Brasil, na sede do Instituto Humanitas Unisinos (IHU). Como exemplo do trabalho desta Fundação, pode-se citar a realização de conferências sobre Ética Mundial, e, dentre outras atividades culturais, a produção de exposição com doze painéis explicativos sobre as religiões mundiais, já exibida em versão inglesa no hall de entrada do edifício da ONU, em Nova York. A Fundação produziu também, em cooperação com a grande emissora de televisão alemã SWR, uma série de sete filmes documentários sobre o tema, acompanhada de livro ilustrado (UNISINOS, Revista do Instituto Humanitas Unisinos, edição 240, 2007. p.4. Disponível em: <http://pt.scribd.com/doc/7991717/6/Hans-Kung-\%E2\%80\%93-Biografia〉. Acesso em: 23 de agosto de 2014, às 22:15h).
} 
associação formada exclusivamente por ex-chefes de Estado e de governo, ${ }^{52}$ em conjunto com Hans Küng e demais peritos, ${ }^{53}$ elaborou a Declaração

${ }^{52}$ O InterAction Council foi fundado em 1983 por Takeo Fukuda (1905-1995; primeiro-ministro do Japão, 1976-1979), e "tem por objetivo fundamental o encorajamento e o aperfeiçoamento da colaboração internacional em três áreas principais: paz e segurança; a revivescência da economia global; desenvolvimento, população e meio ambiente" (KÜNG, Hans; SCHMIDT, Helmut. Uma ética mundial e responsabilidades globais - duas declarações. São Paulo: Loyola, 2001. p. 93). Mais informações sobre o InterAction Council podem ser obtidas no relatório do Fórum de Noordwijk, realizado de $1^{\circ}$ a 4 de junho de 1997, e nas memórias de Helmut Schmidt, Weggefahrten. Erinnerungen und Reflexioen, publicadas em 1996 pela editora Siedler. 575 p.

53 A Declaração Universal das Responsabilidades Humanas recebeu o endosso das seguintes pessoas, em $1^{\circ}$ de setembro de 1977 na cidade de Noordwijk: I) membros do InterAction Council: Helmut Schmidt (presidente honorário), ex-chanceler da República Federal da Alemanha; Malcolm Fraser (presidente), ex-primeiro-ministro da Austrália; Andries A. M. Van Agt, exprimeiro-ministro dos Países Baixos; Anand Panyarachun, ex-primeiro-ministro da Tailândia; Oscar Arias Sánchez, ex-presidente da Costa Rica; Lorde Callaghan de Cardiff, ex-primeiroministro do Reino Unido; Jimmy Carter, ex-presidente dos Estados Unidos; Miguel de la Madrid Hurtado, ex-presidente do México; Kurt Furgler, ex-presidente da Suíça; Válery Giscard d'Estaing, ex-presidente da França; Felipe González Márquez, ex-primeiro-ministro da Espanha; Mikhail Gorbatchev, ex-presidente da União Soviética; Kenneth Kaunda, ex-presidente da Zâmbia; Lee Kuan Yew, ex-primeiro-ministro de Cingapura; Kiich Miyazawa, ex-primeiro-ministro do Japão; Misael Pastrana Borrero, ex-presidente da Colômbia (morto em agosto de 1977); Shimon Peres, ex-primeiro-ministro de Israel; Maria de Lourdes Pintasilgo, ex-primeira-ministra de Portugal; José Sarney, ex-presidente do Brasil; Shin Hyon Hwad, ex-primeiro-ministro da República da Coréia; Kalevi Sorsa, ex-primeiro-ministro da Finlândia; Pierre Elliott Trudeau, ex-primeiroministro do Canadá; Ola Ullsten, ex-primeiro-ministro da Suécia; George Vassiliou, ex-presidente do Chipre; Franz Vranitzky, ex-presidente da Áustria; II) Peritos: Hans Küng (conselheiro acadêmico do projeto, Universidade de Tübingen; Thomas Axworthy (conselheiro acadêmico do projeto), Fundação CRB; Kim, Kyong-dong (conselheiro acadêmico do projeto), Universidade Nacional de Seul; Cardeal Franz König, Viena, Áustria; Anna-Marie Aagaard, Conselho Mundial das Igrejas; M. Shanti Aram, Conferência Mundial sobre Religião e Paz, e membro do Parlamento indiano (morto em junho de 1977); A.T. Ariyaratne, presidente do Movimento Sarvodaya do Sri Lanka; Julia Ching, Universidade de Toronto; Hassan Hanafi, Universidade do Cairo; Nagaharu Hayabusa, Asahi Shimbun, Tóquio; Kim Yersu, diretor da Divisão de Filosofia e Ética, UNESCO; Peter Landesmann, membro da Academia Européia de Ciênias, Salzburg; Lee, Seung-yun, exsuplente do primeiro-ministro e ministro do planejamento econômico da República da Coreia; Flora Lewis, jornalista do Internacional Herald Tribune, Paris; Liu, Xiao-feng, Instituto de Estudos Sino-cristãos, Hong Kong; Teri McLuhan, escritor canadense; Isamu Miyazaki, exministro de Estado, Agência de Planejamento Econômico do Japão, Tóquio; James Ottley, observador anglicano nas Nações Unidas, Nova York; Richard Rorty, Centro de Humanidades de Stanford; L.M. Singvi, alto comissário para a Índia, Londres; Seiken Sugiura, Câmara dos Deputados do Japão, Tóquio; Koji Watanabe, ex-embaixador japonês na Rússia; Woo, Seongyong, Munhwa Ilbo, Seul; Alexander Yakovlev, ex-membro, Conselho Presidencial da União Soviética; III) Apoiadores: Lester Brown, presidente, Worldwatch Institute; André Chouraqui, professor em Israel; John B. Cobb Jr, Claremont, Califórnia, Estados Unidos; Tarako Doi, presidente, Partido Social Democrata do Japão; Ekaterina Genieva, Membro da Duma, Rússia; Marjorie Hewitt Suchocki, reitor, Escola de Teologia, Claremont, Califórnia, Estados Unidos; Henry A. Kisinger, ex-secretário de Estado, Estados Unidos; Teddy Kollek, ex-prefeito de Jerusalém, William Laughlin, empresário americano; H H. Chwasan Lee Kwang Jung, budismo won, Coréia; Dmitry S. Lichatchov, historiador literário, Academia de Ciências, São Petersburgo; Rabi professor J. Magonet, direitor do Leo Baeck College; Robert S. McNamara, ex-presidente, Banco Mundial; Konrad Raiser, secretário geral do Conselho Mundial das Igrejas; Rabi Jonahan Sacks, Londres; Sir Sigmound Sternberg, OStJ SCSG JP, Fórum das Três Fés, Londres; Paul Volcker, presidente, James D. Wolfesohn Inc.; Carl Friedrich von Weizächer, Starnberg; IV) Patronos: Shinyasu Hoshino, presidente, Instituto Nacional para o Avanço da Pesquisa, Tóquio; Ayako Sono, presidente, Fundação Nippon, Tóquio; Kim Woo-Joong, presidente, Dae-Woo 
Universal das Responsabilidades Humanas, na qual foram relacionados princípios éticos globais que deveriam ser seguidos por todos os Estados. Esta Declaração, publicada quase cinquenta anos após a Declaração dos Direitos Humanos das Nações Unidas, tinha por objetivo destacar as responsabilidades éticas de todos os cidadãos, independentemente da nacionalidade, ante a constatação de que "grupos individuais quase sempre insistem nos direitos contra os outros sem reconhecer quaisquer responsabilidades que eles mesmos têm". ${ }^{54}$ Desse modo, a Declaração das Responsabilidades Humanas "revela a possibilidade do acordo - acordo democrático - sobre o que é certo e errado, permissível e proibido", e "proclama para o público mundial algumas normas básicas para a conduta individual e coletiva que se aplica a todos". ${ }^{55}$ Em $1^{\text {o }}$ de setembro de 1997, a Declaração foi publicada em inglês, alemão e japonês, sendo enviada ao secretário-geral da ONU, Kofi Annan, e aos governos nacionais por todo o mundo. A Declaração Universal das Responsabilidades Humanas está agora disponível

[...] em mais de dezesseis línguas - um fato que demonstra o interesse na Declaração e sua disseminação, representando ao mesmo tempo algo novo na história do InterAction Council: ele se tornou um foco de atenção internacional. ${ }^{56}$

Em 2001, após o fatídico episódio ocorrido no dia 11 de setembro, tornou-se mais clara a urgente necessidade de uma ética básica para reger a ordem global, a fim de garantir a estabilidade e a coesão mundial. Explica Küng que, a partir deste momento,

Corporation, Seul. Estas informações foram extraídas de KÜNG, Hans; SCHMIDT, Helmut. Uma ética mundial e responsabilidades globais - duas declarações. São Paulo: Loyola, 2001. p. 10-44. Apesar de esta obra listar todos os que participaram da referida Declaração, é válido ressalvar que não foi esclarecido o critério utilizado para seleção dos membros convidados a subscrever a Declaração.

${ }^{54}$ KÜNG, Hans; SCHMIDT, Helmut. Uma ética mundial e responsabilidades globais - duas declarações. São Paulo: Loyola, 2001. p. 114.

${ }^{55}$ KÜNG, Hans; SCHMIDT, Helmut. Uma ética mundial e responsabilidades globais - duas declarações. São Paulo: Loyola, 2001. p. 114.

${ }^{56}$ MIYAZAKI, Isamu apud KÜNG, Hans; SCHMIDT, Helmut. Uma ética mundial e responsabilidades globais - duas declarações. São Paulo: Loyola, 2001. p. 106. 
Muitos perceberam que não haverá paz entre nações sem que haja paz entre as religiões e que, para tanto, são extremamente importantes padrões éticos comuns. De Jürgen Habermas, à esquerda, ao presidente Chirac, à direita, muitos clamam agora, felizmente, pelo diálogo das culturas, negligenciado por tanto tempo. ${ }^{57}$ [...] Se esse diálogo não se realizar, ou for interrompido, só resta a alternativa da violência: quando os homens não conversam entre si, começam a atirar um contra o outro. ${ }^{58}$

Em razão destes eventos, é possível concluir que Küng em muito contribuiu para o renascimento do processo de busca por uma ética mínima comum à sociedade mundial - processo este ainda não encerrado. Passaremos a abordar, a seguir, os argumentos sustentados por Küng para comprovar a viabilidade de sua proposta, bem como o conteúdo que, segundo o autor, deve integrar essa ética mínima a fim de respeitar a autonomia pessoal dos cidadãos e, ao mesmo tempo, garantir a solidariedade destes últimos com a urdidura social global.

\footnotetext{
${ }^{57}$ HOEREN, Jürgen; KÜNG, Hans. Para que um Ethos Mundial? Religião e ética em tempos de globalização - conversando com Jürgen Hoeren. São Paulo: Edições Loyola, 2005. p. 86.

${ }_{58}$ HOEREN, Jürgen; KÜNG, Hans. Para que um Ethos Mundial? Religião e ética em tempos de globalização - conversando com Jürgen Hoeren. São Paulo: Edições Loyola, 2005. p. 74.
} 


\section{Dos pressupostos do projeto de ética mundial}

Como exposto anteriormente, Hans Küng sustenta a necessidade de uma ética para servir a toda a humanidade, a fim de garantir uma ordem global pacífica e estável, sob o argumento de que

[...] sem moral, sem normas éticas comumente aceitas, sem padrões globais, as nações correm o perigo de, através do acúmulo de problemas de decênios, caminhar para uma crise que pode levar ao colapso nacional, isto é, à ruína econômica, à desmontagem social e à catástrofe política. ${ }^{59}$

Para alcançar seu objetivo unificador, na visão de Küng, o conteúdo dessa ética mínima deve compreender apenas valores mínimos compartilhados por todos, mesmo na situação de pluralismo cultural.

Nesta lógica, o ethos mundial não pode ser baseado em uma só ideologia, nem visar a "uma cultura mundial única, e muito menos uma única religião mundial". ${ }^{60}$ Ao contrário, seu conteúdo deve ser definido por meio de um diálogo intercultural, e deve ser passível de aceitação por religiosos e por não religiosos. ${ }^{61}$

Constata-se, portanto, que Küng se vale de uma premissa ao estabelecer o conteúdo do ethos mundial: a possibilidade de alcançar, por meio de um diálogo intercultural, um consenso global a respeito de princípios éticos que devem ser observados por todos.

Tal premissa, por sua vez, pode ser dividida em três pressupostos: a) a viabilidade de um diálogo intercultural; b) a existência de um consenso global em relação aos princípios éticos; c) a possibilidade de extrair, de um

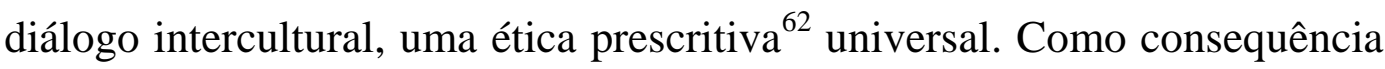

\footnotetext{
${ }^{59}$ KÜNG, Hans. Projeto de Ética Mundial - Uma moral ecumênica em vista da sobrevivência humana. 4. ed. São Paulo: Paulinas, 2003. p. 54.

${ }^{60}$ KÜNG, Hans. Uma Ética Global para a Política e a Economia Mundiais. Petrópolis: Editora Vozes, 1999. p. 168.

${ }^{61}$ HOEREN, Jürgen; KÜNG, Hans. Para que um Ethos Mundial? Religião e ética em tempos de globalização - conversando com Jürgen Hoeren. São Paulo: Edições Loyola, 2005. p. 85.

${ }^{62}$ Conforme esclarece Noel Struchiner, no artigo "O direito como um campo de escolhas: por uma leitura das regras prescritivas como relações", a linguagem prescritiva (ou normativa) é aquela que "pretende influenciar comportamentos" (STRUCHINER, Noel. O direito como um campo de escolhas: por uma leitura das regras prescritivas como relações. In: BARBOSA, Samuel Rodrigues; DA SILVA E COSTA, Carlos Eduardo Batalha; RODRIGUEZ, José Rodrigo (Orgs). Nas Fronteiras do Formalismo - A Função Social da Dogmática Jurídica Hoje. São Paulo:
} 
lógica desta assertiva, conclui-se que os céticos quanto ao diálogo entre defensores de diferentes visões de mundo em relação a princípios éticos universais ou a éticas prescritivas, não aceitarão o projeto de Küng motivo pelo qual o autor se preocupa em abordar estas questões em suas obras sobre o tema "ethos mundial". Para melhor compreender o pensamento de Küng, passaremos a analisar, a seguir, os argumentos utilizados pelo autor para comprovar cada um destes pressupostos.

\subsection{Da viabilidade de um diálogo intercultural}

A proposta de ética mundial de Küng embasa-se na viabilidade de um diálogo (ou melhor, de um processo dinâmico ${ }^{63}$ de diálogo constante) entre protagonistas de diferentes visões de mundo. Desta forma, considerando que o diálogo é o método proposto por Küng para definição do conteúdo do ethos mundial, torna-se imprescindível que estudemos os argumentos utilizados pelo autor para comprovar o referido pressuposto - é certo que, em relação a este aspecto, o autor aborda com especial atenção o diálogo inter-religioso.

Sustenta Küng que, se houver um esforço por parte dos interlocutores para "chegar a parâmetros éticos comuns" ${ }^{64}$, o diálogo será possível. Este esforço, por sua vez, traduz-se nas seguintes posturas:

a) postura de tolerância em relação às outras crenças, não no sentido de indiferentismo (apatia no que diz respeito ao que o outro prega), mas no

\footnotetext{
Editora Saraiva, 2010. p. 103). Sobre o tema, cabe transcrever a diferenciação entre ética normativa e ética descritiva, feita por Adela Cortina e Emílio Martínez: "Alguns filósofos morais descreveram o modo como as pessoas se comportam de fato em assuntos morais, ao passo que outros argumentaram sobre o modo como as pessoas devem se comportar. O primeiro enfoque corresponderia a uma ética descritiva, ao passo que o segundo seria próprio de uma ética normativa. Nesse mesmo sentido, J. Hierro distinguia: a) a ética descritiva, que considera a moral um fenômeno a ser descrito e explicado; b) a ética normativa, que considera a moral um conteúdo a ser recomendado" (CORTINA, Adela; MARTÍNEZ NAVARRO, Emílio. Ética. São Paulo: Edições Loyola. 2005. p. 104). Assim, conclui-se que a proposta de ética mundial de Hans Küng é prescritiva, na medida em que se traduz em uma "doutrina filosófica e teológica sobre os valores e as normas que devem orientar nossas decisões e ações" (KÜNG, Hans. Projeto de Ética Mundial Uma moral ecumênica em vista da sobrevivência humana. 4. ed. São Paulo: Paulinas, 2003. p. 54).

${ }^{63}$ KÜNG, Hans. Projeto de Ética Mundial - Uma moral ecumênica em vista da sobrevivência humana. 4. ed. São Paulo: Paulinas, 2003. p. 58.

${ }^{64}$ KÜNG, Hans; SCHMIDT, Helmut. Uma ética mundial e responsabilidades globais - duas declarações. São Paulo: Loyola, 2001. p. 131.
} 
sentido de respeitar qualquer ortodoxia que se coloque "[...] como medida para salvação ou perdição das pessoas"; ${ }^{65}$

b) postura de sensibilidade em relação aos preceitos das demais visões de mundo; ${ }^{66}$

c) postura de busca por uma síntese, entendida como paulatina convergência em face de todas as contradições e antagonismos confessionais; ${ }^{67}$

d) postura totalmente aberta para o diálogo, sem abdicar das próprias visões de mundo e das próprias tradições, ou seja, mantendo firmeza de posição; ${ }^{68}$

e) postura autocrítica em relação às próprias visões de mundo. ${ }^{69}$

A título de exemplo, explica o autor que os interlocutores - os quais, cabe esclarecer, deverão ter igual direito a voz - precisam: a) inicialmente, ouvir o que os demais participantes da conversa têm a dizer a respeito de determinada situação; ${ }^{70}$ b) em seguida, buscar compreender o ponto de vista apresentado, com base nas diferentes tradições das culturas dos seus interlocutores, seus fundamentos e suas figuras salvíficas; ${ }^{71}$ c) ao final, preocupar-se em explicar

[...] ao parceiro de diálogo a sua própria posição e esperar dele somente a disposição incondicional de ouvir e aprender, isto é, uma abertura ilimitada, que inclui uma transformação dos parceiros de diálogo no decorrer do processo de entendimento. Isso é um caminho paciente e realista. $^{72}$

\footnotetext{
${ }^{65}$ KÜNG, Hans. Projeto de Ética Mundial - Uma moral ecumênica em vista da sobrevivência humana. 4. ed. São Paulo: Paulinas, 2003. p. 155.

${ }^{66}$ KÜNG, Hans. Projeto de Ética Mundial - Uma moral ecumênica em vista da sobrevivência humana. 4. ed. São Paulo: Paulinas, 2003. p. 155.

${ }^{67}$ KÜNG, Hans. Projeto de Ética Mundial - Uma moral ecumênica em vista da sobrevivência humana. 4. ed. São Paulo: Paulinas, 2003. p. 163.

${ }^{68}$ KÜNG, Hans. Projeto de Ética Mundial - Uma moral ecumênica em vista da sobrevivência humana. 4. ed. São Paulo: Paulinas, 2003. p. 163.

${ }^{69}$ KÜNG, Hans. Projeto de Ética Mundial - Uma moral ecumênica em vista da sobrevivência humana. 4. ed. São Paulo: Paulinas, 2003. p. 163.

${ }^{70}$ KÜNG, Hans. Projeto de Ética Mundial - Uma moral ecumênica em vista da sobrevivência humana. 4. ed. São Paulo: Paulinas, 2003. p. 163.

${ }^{71}$ KÜNG, Hans. Projeto de Ética Mundial - Uma moral ecumênica em vista da sobrevivência humana. 4. ed. São Paulo: Paulinas, 2003. p. 163.

${ }^{72}$ KÜNG, Hans. Projeto de Ética Mundial - Uma moral ecumênica em vista da sobrevivência humana. 4. ed. São Paulo: Paulinas, 2003. p. 163.
} 
Para o autor, observadas essas posturas, torna-se factível a conversa com integrantes das mais diversas culturas, até mesmo com os defensores de vertentes religiosas consideradas fundamentalistas ${ }^{73}$ - é válido enfatizar o fato de que, na visão de Küng, o fundamentalismo encontra-se presente nas mais diversas religiões, tais como o Islamismo (fundamentalistas islâmicos), o Judaísmo (ultraortodoxos judeus) e o Catolicismo (tradicionalistas católicos). ${ }^{74}$ Nas palavras de Küng:

[...] certos padrões éticos estão presentes em todas as religiões, e sobre eles se pode conversar perfeitamente também com um fundamentalista. [...] Um diálogo amplo só é possível quando se procura chegar a parâmetros éticos comuns [...]. É justamente esse diálogo que tenho defendido há muitos anos e que, naturalmente, pode ser aperfeiçoado. ${ }^{75}$

Em termos concretos, argumenta o filósofo que a viabilidade de um diálogo sincero entre representantes dos mais diversos Estados e religiões a respeito de um ethos mundial já foi confirmada em diversas ocasiões ${ }^{76}$, dentre as quais merecem destaque, como já mencionado anteriormente: a) o Parlamento das Religiões do Mundo realizado em Chicago em 1993, ${ }^{77}$ quando representantes de uma variedade de religiões, grandes e pequenas, debateram o texto sugerido para a Declaração do Parlamento das Religiões

\footnotetext{
${ }^{73}$ Küng critica a utilização do termo "fundamentalista" como sinônimo de "terrorista", sob o argumento de que o adjetivo "fundamentalista" refere-se a vertentes que pregam a revitalização dos princípios fundamentais de religiões. Para o autor, não é correto atribuir ao termo "fundamentalista" sentido pejorativo em razão da forma pela qual alguns grupos fundamentalistas específicos se comportaram. Para uma análise pormenorizada do posicionamento de Küng em relação ao termo "fundamentalista", conferir KÜNG, Hans; SCHMIDT, Helmut. Uma ética mundial e responsabilidades globais - duas declarações. São Paulo: Loyola, 2001. p. 129-133. Sobre o fundamentalismo, conferir também KÜNG, Hans. Uma Ética Global para a Política e a Economia Mundiais. Petrópolis: Editora Vozes, 1999. p. 168.

${ }^{73}$ KÜNG, Hans. Para que um Ethos Mundial? Religião e ética em tempos de globalização conversando com Jürgen Hoeren. São Paulo: Edições Loyola, 2005. p. 129-133

${ }^{74}$ KÜNG, Hans; SCHMIDT, Helmut. Uma ética mundial e responsabilidades globais - duas declarações. São Paulo: Loyola, 2001. p. 129-133.

${ }^{75}$ HOEREN, Jürgen; KÜNG, Hans. Para que um Ethos Mundial? Religião e ética em tempos de globalização - conversando com Jürgen Hoeren. São Paulo: Edições Loyola, 2005. p. 131.

${ }^{76}$ KÜNG, Hans. Uma Ética Global para a Política e a Economia Mundiais. Petrópolis: Editora Vozes, 1999. p. 170.

${ }^{77}$ Para mais informações a respeito do Parlamento das Religiões do Mundo, realizado em Chicago, 1993, conferir o capítulo "Do contexto no qual se evidencia a necessidade de uma ética mundial", e o capítulo "As declarações de ética mundial".
} 
do Mundo, cujo anteprojeto foi elaborado por Küng - declaração esta que, para o autor, poderia ser traduzida como uma primeira tentativa de mapeamento do ethos mundial da humanidade; ${ }^{78}$ b) o encontro promovido em 1997 pela InterAction Council, no qual ex-chefes dos mais diversos Estados, em conjunto com Hans Küng e demais peritos, discutiram o conteúdo da Declaração Universal das Responsabilidades Humanas, na qual foram relacionados princípios éticos globais que deveriam ser seguidos por todos os Estados. ${ }^{79}$

Vale destacar, porém, que esses encontros, na opinião de Küng, não representam "o fim, mas apenas o começo" ${ }^{80}$ de um processo de diálogo intercultural a respeito do tema "ética mundial", e deveriam continuar sendo promovidos, com a promulgação de novas declarações "que tornem a ética mundial [...] mais precisa e concreta e lhe acrescentem mais exemplos concretos". ${ }^{81}$ Não obstante, a busca pelo ethos mundial, para o autor, deve ser constante, e não deve se limitar "somente a conferências e reuniões" ${ }^{82}$, mas também deve incluir: a) "intensivos contatos institucionais e relações bilaterais"; ${ }^{83}$ b) diálogos no dia a dia, ${ }^{84}$ em níveis locais e regionais, com a finalidade de tornar as pessoas "mais bem informadas e orientadas sobre as pessoas de outros lugares e culturas [...] e nisso, simultaneamente aprofundem a compreensão e a própria prática da religião"; ${ }^{85}$ c) diálogos na esfera política, para que os protagonistas das relações internacionais não

\footnotetext{
${ }^{78}$ HOEREN, Jürgen; KÜNG, Hans. Para que um Ethos Mundial? Religião e ética em tempos de globalização - conversando com Jürgen Hoeren. São Paulo: Edições Loyola, 2005, p. 29.

79 Para mais informações a respeito do encontro promovido pelo InterAction Council e da Declaração de Responsabilidades Humanas, conferir "Do contexto no qual se evidencia a necessidade de uma ética mundial", e o capítulo "As declarações de ética mundial".

${ }^{80}$ KÜNG, Hans; SCHMIDT, Helmut. Uma ética mundial e responsabilidades globais - duas declarações. São Paulo: Loyola, 2001. p. 48.

${ }^{81}$ KÜNG, Hans; SCHMIDT, Helmut. Uma ética mundial e responsabilidades globais - duas declarações. São Paulo: Loyola, 2001. p. 48.

${ }^{82}$ KÜNG, Hans. Projeto de Ética Mundial - Uma moral ecumênica em vista da sobrevivência humana. 4. ed. São Paulo: Paulinas, 2003. p. 209.

${ }^{83}$ KÜNG, Hans. Projeto de Ética Mundial - Uma moral ecumênica em vista da sobrevivência humana. 4. ed. São Paulo: Paulinas, 2003. p. 209.

${ }^{84}$ KÜNG, Hans. Projeto de Ética Mundial - Uma moral ecumênica em vista da sobrevivência humana. 4. ed. São Paulo: Paulinas, 2003. p. 209.

${ }^{85}$ KÜNG, Hans. Projeto de Ética Mundial - Uma moral ecumênica em vista da sobrevivência humana. 4. ed. São Paulo: Paulinas, 2003. p. 206.
} 
analisem os novos problemas da política mundial "somente a partir da perspectiva de sobrecomandos estratégicos ou do mercado mundial, mas que anseiem por realizar uma concepção de paz internacional"; ${ }^{86}$ d) diálogos voltados para a economia, a fim de que os responsáveis por políticas econômicas não enxerguem

[...] pessoas de outros países ou culturas [...] como prestadores de serviços ou como simples parceiros, mas que, para além de seu estreito setor econômico, procurem ver seus parceiros de forma integral e busquem ter sensibilidade para com a história, a cultura e a relação das outras pessoas com as quais estão em relação. ${ }^{87}$

Expostos os argumentos do autor para sustentar a viabilidade de um diálogo entre defensores de diferentes visões de mundo, questiona-se: deste diálogo, é possível extrair princípios éticos universais?

\subsection{Da existência de um consenso global de princípios éticos}

Para comprovar a factibilidade de sua proposta, preocupa-se Küng em demonstrar que existem valores éticos compartilhados por todas as culturas.

Com esse objetivo, o autor, em primeiro lugar, explica que a existência de pontos em comum na consciência ética mundial é empiricamente verificável: determinadas situações provocam indignação em países do mundo inteiro, ${ }^{88}$ e este aspecto comprova que, na "percepção dos conflitos políticos, pode ser constatado um elemento universal". ${ }^{89} \mathrm{Nas}$ palavras de Küng:

Hoje, com determinadas ocorrências locais, o mundo inteiro se enche de indignação. Quando as massas humanas são impelidas às ruas e as

\footnotetext{
${ }^{86}$ KÜNG, Hans. Projeto de Ética Mundial - Uma moral ecumênica em vista da sobrevivência humana. 4. ed. São Paulo: Paulinas, 2003. p. 206.

${ }^{87}$ KÜNG, Hans. Projeto de Ética Mundial - Uma moral ecumênica em vista da sobrevivência humana. 4. ed. São Paulo: Paulinas, 2003. p. 206.

${ }^{88}$ KÜNG, Hans. Uma Ética Global para a Política e a Economia Mundiais. Petrópolis: Editora Vozes, 1999. p. 170.

${ }^{89}$ WALZER, Michael. Thick and Thin. Moral Argument at Home and Abroad, Notre Dame/Ind. 1994. Edição alemã: Lokale Kritik - globale Standards. Swei Sormem moralischer Auseinandersetzung, Hamburgo, 1996 apud KÜNG, Hans. Uma Ética Global para a Política e a Economia Mundiais. Petrópolis: Editora Vozes, 1999. p. 171.
} 
marchas de protesto - ocorram elas em Pequim, Buenos Aires, Rangum, Bruxelas ou Belgrado - são transmitidas para o mundo através da televisão, então por toda parte um sem-número de pessoas tomam parte neste acontecimento, identificam-se com as pessoas do lugar e acompanham-nas em espírito; muitas vezes é só a opinião pública mundial que força os políticos do Ocidente, tantas vezes oportunistas e hipócritas, a tomarem uma atitude. Neste fenômeno se manifesta um aspecto que os valores elementares têm em comum e que vale a pena ser lembrado. ${ }^{90}$

Tal fenômeno, argumenta o autor, é reconhecido mesmo por defensores do pluralismo ético ${ }^{91}$ (ou relativismo ético), como o professor de ciências sociais em Princeton, Michael Walzer:

Contra todos que de maneira regionalista ou relativista contestam as idéias de valores universalmente válidos e de exigências morais, Michael Walzer torna claro, de maneira diferenciada, que existe algo assim como um "núcleo da moral": todo um feixe de padrões éticos elementares, dos quais fazem parte o direito fundamental à vida, ao justo tratamento (também por parte do Estado), à integridade corporal e psíquica. Walzer chama isto de uma "moral mínima" ou um "minimalismo moral". O que ele pretende dizer são conceitos morais que possuem um mínimo de significado e que são reproduzidos por meio de uma descrição "fina": uma moral "fina", portanto, que nas diversas culturas, evidentemente enriquecida de conteúdo, reaparece como uma moral "grossa", para a qual de múltiplas maneiras concorrem, segundo o tempo e o lugar, todas as possíveis visões históricas, culturais, religiosas e políticas. ${ }^{92}$

Para Küng, ao reconhecer, por meio da análise de situações concretas, a existência de uma "moral fina" comum aos grupos sociais, Michael Walzer se diferenciou de duas importantes correntes filosóficas de nosso tempo, as quais, a despeito de criticarem o utilitarismo como fundamentação dos deveres normativos, fornecem respostas demasiadamente abstratas para o mundo atual:

Por esta abordagem concreta, Walzer distingue-se [...] [...] por um lado, de John Rawls, que a partir de princípios gerais de justiça, como correção do agir ("fairness"), deduz e aplica regras éticas, porém abstraindo conscientemente de contextos e situações concretas; só uma idéia ampliada de justiça permite a Rawls, a posteriori,

\footnotetext{
${ }^{90}$ KÜNG, Hans. Uma Ética Global para a Política e a Economia Mundiais. Petrópolis: Editora Vozes, 1999. p. 171.

${ }^{91}$ KÜNG, Hans. Uma Ética Global para a Política e a Economia Mundiais. Petrópolis: Editora Vozes, 1999. p. 171.

${ }^{92}$ KÜNG, Hans. Uma Ética Global para a Política e a Economia Mundiais. Petrópolis: Editora Vozes, 1999. p. 173.
} 
desenvolver para o direito e a justiça uma concepção que também pode ser aplicada aos princípios e normas do direito internacional e das relações internacionais;

Por outro lado, da ética discursiva construtivista de Karl-Otto Apel e Jürgen Habermas, que com razão sublinham o significado do consenso e do discurso racional, mas que acham que de uma forma pretensamente independente do contexto podem desenvolver normas de incontestável validade a partir da comunidade da comunicação e de argumentação humana; as razões religiosas e as interpretações da moral, que pretensamente teriam perdido o valor para a opinião pública, devem ser substituídas pelo discurso racional, pelo jogo de palavras da moral, pela "força de pressão do argumento sem pressão". ${ }^{93}$

As propostas éticas rawlsiana e habermasiana, na visão do autor, não levam em consideração o fato de que, "em face da relevância concreta das religiões e das culturas, parece muito questionável impor agora com auxílio de um discurso racional abstrato um ethos global realmente vinculante e obrigatório (que, por assim dizer, atinja até a mais afastada aldeia indiana ou africana)". ${ }^{94}$ Por este motivo, não podem tais correntes filosóficas servir de base para o projeto de ética mundial de Hans Küng, uma vez que ignoram as diferenças que "de fato existem na sociedade mundial em perspectiva múltipla"95 - sendo certo que, para o filósofo, "seria ilusório pensar que poderíamos eliminá-las todas". ${ }^{96}$ Desta forma, tanto o discurso ralwsiano quanto a ética discursiva construtivista de Karl-Otto Apel e Jürgen Habermas inviabilizariam o consenso mundial pretendido por Küng.

No mesmo erro incorreriam os defensores da ideia de que todos os indivíduos devem obedecer a uma moral com "exigências rigorosas bem concretas, como as da doutrina moral católico-romana tradicionalista".97

\footnotetext{
${ }^{93}$ KÜNG, Hans. Uma Ética Global para a Política e a Economia Mundiais. Petrópolis: Editora Vozes, 1999. p. 174.

${ }^{94}$ KÜNG, Hans. Uma Ética Global para a Política e a Economia Mundiais. Petrópolis: Editora Vozes, 1999. p. 174.

${ }^{95}$ UNISINOS, Revista do Instituto Humanitas Unisinos, edição 240, 2007. p.8. Disponível em: <http://pt.scribd.com/doc/7991717/6/Hans-Kung-\%E2\%80\%93-Biografia>. Acesso em: 18 de setembro de 2014, às 10:41h.

${ }^{96}$ UNISINOS, Revista do Instituto Humanitas Unisinos, edição 240, 2007. p. 8. Disponível em: <http://pt.scribd.com/doc/7991717/6/Hans-Kung-\%E2\%80\%93-Biografia>. Acesso em: 18 de setembro de 2014, às 10:45h.

${ }^{97}$ UNISINOS, Revista do Instituto Humanitas Unisinos, edição 240, 2007. p. 7. Disponível em: <http://pt.scribd.com/doc/7991717/6/Hans-Kung-\%E2\%80\%93-Biografia>. Acesso em: 18 de setembro de 2014, às 10:48h.
} 
Neste sentido, também não poderia o direito natural servir como base para uma ética mundial. Nas palavras de Küng:

O tradicional direito natural é pouco apropriado para isso: é verdade que ele tem atrás de si uma grande tradição greco-escolástica, mas padece há tempo sob dois percalços: 1. Ele é encarado de maneira demasiado estática e não faz jus ao constante desenvolvimento ulterior, também da moral. 2. Abusou-se dele com freqüência, para, por exemplo,em questões da moral social e sexual, fixar determinadas normas que se desenvolveram historicamente como sendo de direito natural. Acima de tudo, foi prejudicial que se tenha estigmatizado como imoral qualquer meio anticoncepcional, porque seria contra naturam. Uma ética contemporânea quase não fala da natureza, porém da pessoa ou do indivíduo humano. ${ }^{98}$

Assim, o trunfo de Walzer, na visão de Küng, consistiria no reconhecimento de que: a) o "jogo de palavras da moral" e o "argumento livre de pressão" não detêm a mesma força vinculante e obrigacional que os padrões éticos usuais de cada região $;^{99}$ b) ainda assim, é possível observar que alguns princípios éticos são universalmente válidos - e em relação a estes princípios, é possível um consenso ético global. ${ }^{100}$

O estudo de Walzer comprova, portanto, a existência de princípios éticos seguidos por todas as culturas. Destes princípios, sustenta o professor de Princeton, extraem-se enunciados negativos que, para o cientista social, podem ser resumidos em: proibição do genocídio, proibição da escravidão e proibição do tratamento cruel. $^{101}$

Desta conclusão, impõe-se a pergunta: seria a "moral fina" de Walzer suficiente para embasar o ethos mundial proposto por Hans Küng? A resposta é negativa, conforme será explicado em detalhes a seguir.

\footnotetext{
${ }^{98}$ UNISINOS, Revista do Instituto Humanitas Unisinos, edição 240, 2007. p. 8. Disponível em: <http://pt.scribd.com/doc/7991717/6/Hans-Kung-\%E2\%80\%93-Biografia〉. Acesso em: $18 \mathrm{de}$ setembro de 2014, às 10:46h.

${ }_{99}$ KÜNG, Hans. Uma Ética Global para a Política e a Economia Mundiais. Petrópolis: Editora Vozes, 1999. p. 174.

${ }^{100}$ KÜNG, Hans. Uma Ética Global para a Política e a Economia Mundiais. Petrópolis: Editora Vozes, 1999. p. 177.

${ }^{101}$ Conferir WALZER, Michael. Moralidad en el Ámbito Local e Internacional. Tradução de Rafael Del Águila. Madrid: Alianza, 1996. p. 26.
} 


\subsection{Da possibilidade de extrair, de um diálogo intercultural, uma ética prescritiva universal}

Como exposto anteriormente, Hans Küng se utiliza do estudo de Walzer para comprovar a existência de princípios éticos universalmente compartilhados. O minimalismo ético ${ }^{102}$ de Walzer, porém, não é suficiente para embasar a proposta de ética mundial de Hans Küng.

Walzer, na obra Thick and Thin. Moral Argument at Home and Abroad, define "moral fina" como aquela composta por valores reconhecidos por defensores de diferentes culturas morais:

El minimalismo [...] es menos un producto de la persuasión que del mutuo reconocimiento entre los protagonistas de diferentes culturas morales completamente desarrolladas. Consiste en principios y reglas reiterados en diferentes tiempos y lugares y que se consideran similares aun cuando se expresan en diferentes idiomas y reflejan historias diversas y visiones del mundo distintas. ${ }^{103}$

O cientista social, portanto, se limita a descrever os princípios universalmente compartilhados por todas as culturas - sustentando, a partir desta análise descritiva, a ideia de que o descumprimento destes princípios (ou, em outras palavras, a prática de condutas vedadas pelos enunciados proibitivos que podem ser extraídos destes princípios) é passível de crítica $^{104}$ pelas demais culturas.

Desta forma, não manifesta Walzer intenção de indicar uma ética prescritiva autônoma, composta por princípios e condutas que devem ser praticadas por todos; a "moral fina" apenas se presta a justificar a crítica à prática de atos que, por meio de um estudo descritivo, são classificados como universalmente condenados ${ }^{105}$.

\footnotetext{
102 A expressão "minimalismo ético" é utilizada por Walzer na obra WALZER, Michael. Moralidad en el Ámbito Local e Internacional. Tradução de Rafael Del Águila. Madrid: Alianza, 1996 -, não possuindo o sufixo "ismo", neste caso, qualquer conotação negativa.

${ }^{103}$ WALZER, Michael. Moralidad en el Ámbito Local e Internacional. Tradução de Rafael Del Águila. Madrid: Alianza, 1996. p. 49.

${ }^{104}$ WALZER, Michael. Moralidad en el Ámbito Local e Internacional. Tradução de Rafael Del Águila. Madrid: Alianza, 1996. p. 42.

${ }^{105}$ É válido destacar que Michael Walzer, ao justificar a crítica a determinadas condutas com base no estudo descritivo daquilo que é aceito por todas as culturas, foi acusado de cometer a falácia
} 
Por este motivo, os componentes da "moral fina" de Walzer não são suficientes para pautar a proposta de ética mundial de Hans Küng. ${ }^{106}$

Em outras palavras, o conteúdo da "moral fina" de Walzer é meramente descritivo, enquanto a proposta de Hans Küng traduz-se em uma ética prescritiva para toda a humanidade - ainda que uma ética modesta, pois formada por princípios éticos elementares, defendidos por todas as culturas. Por este motivo, afirma Küng que o ethos mundial não pode oferecer unicamente um mínimo "fino" ${ }^{107}$ de consciência ética, nem conter apenas "generalizações questionáveis e modelos pragmáticos". ${ }^{108}$

Essa observação, porém, desencadeia outro questionamento: como formular uma ética prescritiva para toda a humanidade?

Hans Küng deixa claro que os interlocutores, ao iniciarem o diálogo, precisam estar dispostos a realizar uma autocrítica ${ }^{109}$ - ou seja, devem mostrar-se abertos não apenas a conversar sobre o que é efetivamente praticado por cada cultura (plano do ser), mas também a debater aquilo que deve ser posto em prática (plano do dever ser).

A partir do diálogo entre as diferentes culturas, seria possível extrair, na opinião de Küng, não apenas uma declaração daquilo hoje posto em prática pelos protagonistas de diferentes visões de mundo, mas uma

\footnotetext{
naturalista, entendida como a passagem do plano do ser para o plano do dever ser. Para uma análise detalhada da crítica feita a Michael Walzer, conferir CIOTOLA, Marcello Raposo. Relativismo, Universalismo e Justiça Distributiva: um estudo sobre a teoria da igualdade complexa e a teoria da justiça como imparcialidade. Rio de Janeiro. 2005. 255 p. Tese de Doutorado em Filosofia do Direito - Departamento de Direito da PUC-Rio. <Disponível em: http://www.maxwell.vrac.puc-rio.br/Busca_etds.php?strSecao=resultado\&nrSeq=6220@1>.

Acesso em: 09 de outubro de 2014, às 22:10. Desta obra também constam indicações de autores que bem explicam o conceito de falácia naturalista, tais como MOORE, George Edward. Principia Ethica. Tradução de Márcio Pugliesi e Divaldo Roque de Meira. São Paulo: Ícone, 1998. parágrafos 10 a 14, e SÁNCHEZ VÁZQUEZ, Adolfo. Ética. 21ª ed. Tradução de João Dell'Anna. Rio de Janeiro: Civilização Brasileira, 1992. p. 250.

${ }^{106}$ KÜNG, Hans. Uma Ética Global para a Política e a Economia Mundiais. Petrópolis: Editora Vozes, 1999. p. 189.

${ }^{107}$ KÜNG, Hans. Uma Ética Global para a Política e a Economia Mundiais. Petrópolis: Editora Vozes, 1999. p. 189.

${ }^{108}$ KÜNG, Hans. Uma Ética Global para a Política e a Economia Mundiais. Petrópolis: Editora Vozes, 1999. p. 189.

${ }^{109}$ KÜNG, Hans; SCHMIDT, Helmut. Uma ética mundial e responsabilidades globais - duas declarações. São Paulo: Loyola, 2001. p. 63.
} 
verdadeira ética prescritiva, traduzida na ética básica elementar que pode ser exigida ao homem. ${ }^{110}$

${ }^{110}$ KÜNG, Hans. Uma Ética Global para a Política e a Economia Mundiais. Petrópolis: Editora Vozes, 1999. p. 197. 


\section{Dos protagonistas do projeto de ética mundial}

Küng sugere o diálogo intercultural amplo como método para definição do conteúdo do ethos mundial. Este ethos mundial, por sua vez, serviria como ética prescritiva para toda a humanidade. No entanto, Küng demonstra especial dedicação em justificar a adesão de líderes religiosos, líderes políticos e economistas ${ }^{111}$ ao seu projeto, pelos argumentos a seguir expostos - na medida em que, para o autor, estes líderes devem ser os principais protagonistas na busca pelo ethos mundial.

\subsection{Dos religiosos na busca pelo ethos mundial}

Hans Küng deixa claro que o projeto de ethos mundial busca fornecer uma ética prescritiva para todo e qualquer homem - inclusive para religiosos das mais diversas vertentes, agnósticos, ateístas, e pessoas que não creem. ${ }^{112}$ Crentes e não crentes, portanto, na visão do filósofo, devem engajar-se conjuntamente para a busca da ética mundial, uma vez que é de interesse de todos resistir contra o "niilismo trivial, contra o cinismo difuso e contra a frieza social". ${ }^{113}$

No entanto, apesar de o ethos mundial não ser voltado apenas para religiosos, é inegável a preocupação diferenciada ${ }^{114}$ do autor com a adesão dos líderes religiosos ao seu projeto. ${ }^{115}$

Na primeira obra sobre o tema "ética mundial", Küng apresenta três argumentos que justificam seu empenho em relação aos religiosos, os quais estudaremos a seguir.

Em primeiro lugar, o autor considera que o diálogo inter-religioso é um elemento fundamental para uma ordem mundial pacífica - em última

\footnotetext{
${ }^{111}$ HOEREN, Jürgen; KÜNG, Hans. Para que um Ethos Mundial? Religião e ética em tempos de globalização - conversando com Jürgen Hoeren. São Paulo: Edições Loyola, 2005. p. 157.

${ }^{112}$ HOEREN, Jürgen; KÜNG, Hans. Para que um Ethos Mundial? Religião e ética em tempos de globalização - conversando com Jürgen Hoeren. São Paulo: Edições Loyola, 2005. p. 85.

${ }^{113}$ KÜNG, Hans. Projeto de Ética Mundial - Uma moral ecumênica em vista da sobrevivência humana. 4. ed. São Paulo: Paulinas, 2003. p. 20.

${ }^{114}$ KÜNG, Hans. Projeto de Ética Mundial - Uma moral ecumênica em vista da sobrevivência humana. 4. ed. São Paulo: Paulinas, 2003. p. 107.

${ }^{115} \mathrm{Na}$ obra de KÜNG, Hans. Projeto de Ética Mundial - Uma moral ecumênica em vista da sobrevivência humana. 4. ed. São Paulo: Paulinas, 2003, o autor dedica mais da metade dos capítulos do livro para tratar especificamente da postura dos religiosos na busca do ethos mundial.
} 
instância, o objetivo do ethos mundial: "Não haverá sobrevivência humana sem uma ética mundial. Não haverá paz no mundo sem paz entre as religiões". ${ }^{116}$

Neste sentido, complementa o autor:

[...] muitas discussões, conflitos sangrentos, e sim, guerras religiosas vão por conta das religiões. Diversos conflitos econômico-militares foram em parte causados pelas religiões, em parte motivados e inspirados e até legitimados - isso vale também para as duas grandes guerras mundiais. ${ }^{117}$

Menciona ainda Küng, como exemplo de conflitos iniciados em decorrência de divergências religiosas: os conflitos entre cristãos maronitas e muçulmanos; entre sunitas e xiitas; entre palestinenses, dursos e israelentes; entre o Irã e o Iraque; entre indianos e paquistaneses; entre hinduístas e siks; entre budistas segaleses e hinduístas do Ceilão; entre monges budistas e o regime católico no Vietnã; e entre católicos e protestantes na Irlanda do Norte. ${ }^{118}$

Todas essas guerras, na visão do filósofo, poderiam ter sido evitadas se tivesse havido, em momento anterior, por parte das comunidades religiosas, a busca por um diálogo inter-religioso - diálogo este que, ao possibilitar um entendimento ecumênico, amenizaria o fanatismo religioso da violência, dos assassinatos e da destruição. ${ }^{119}$ Para melhor esclarecer sua visão, cita o autor o caso do Líbano - país que, no ano de 1967, ou seja, poucos anos antes da eclosão da guerra civil, teve a oportunidade de visitar: $^{120}$

[...] se há 25 anos tivesse sido buscado um diálogo sério entre cristãos e muçulmanos e se esta iniciativa tivesse sigo apoiada pelas comunidades religiosas, o Líbano não teria enfrentado uma catástrofe de tamanha dimensão. Um entendimento religioso teria podido servir de base para uma solução política sensata e justa. [...] Num espírito

\footnotetext{
${ }^{116}$ KÜNG, Hans. Projeto de Ética Mundial - Uma moral ecumênica em vista da sobrevivência humana. 4. ed. São Paulo: Paulinas, 2003. p. 7.

${ }^{117}$ KÜNG, Hans. Projeto de Ética Mundial - Uma moral ecumênica em vista da sobrevivência humana. 4. ed. São Paulo: Paulinas, 2003. p. 124.

${ }^{118}$ KÜNG, Hans. Projeto de Ética Mundial - Uma moral ecumênica em vista da sobrevivência humana. 4. ed. São Paulo: Paulinas, 2003. p. 124.

${ }^{119}$ KÜNG, Hans. Projeto de Ética Mundial - Uma moral ecumênica em vista da sobrevivência humana. 4. ed. São Paulo: Paulinas, 2003. p. 123.

${ }^{120}$ KÜNG, Hans. Projeto de Ética Mundial - Uma moral ecumênica em vista da sobrevivência humana. 4. ed. São Paulo: Paulinas, 2003. p. 123.
} 
cristão de renúncia ao poder, os cristãos, já na década de 1970, poderiam ter feito livremente as concessões aos muçulmanos. Mais tarde, na década de 1980, estas seriam conquistadas com a força das armas ao governo de Gamayel e não mais conseguiriam trazer um clima de paz ao país. Em resumo, a guerra civil e o banho de sangue poderiam ter sido evitados. Em vez de um caos horripilante, o Líbano estaria hoje aí como exemplo de entendimento ecumênico. Também estou convencido de que, assim como o Líbano, também o Estado de Israel e a cidade de Jerusalém poderão achar a paz e a firmeza através de um diálogo religioso e político entre judeus, muçulmanos, israelenses e palestinenses. A paz não será achada através de uma sétima ou oitava guerra. ${ }^{121}$

Não obstante, Küng ressalta a ideia de que as religiões também podem contribuir de forma significativa para a paz, por meio do estímulo ao pacifismo, à renúncia ao poder e à tolerância. ${ }^{122}$ Para comprovar tal assertiva, o filósofo se vale de exemplos históricos, dos quais destacamos o "movimento pelos direitos humanos nos Estados Unidos na década de 1960", ${ }^{123}$ "liderado por um pastor negro, Martin Luther King, e sustentado por muitos outros pastores, sacerdotes, irmãs", ${ }^{124}$ bem como o caso da República Federal da Alemanha e dos países do Pacto de Varsóvia, detalhadamente explicado por Küng:

[...] após a Segunda Guerra Mundial, os polos ideológicos entre República Federal da Alemanha e os países do Pacto de Varsóvia estavam completamente acirrados: como as pessoas poderiam se perdoar mutuamente após os terrores dos alemães no leste e da expulsão de milhares de alemães de suas terras? Já no final da década de 1950, o então bispo de Berlim e posterior cardeal de Munique, Julius Döpfner, conclamou as nações para a reconciliação, dando assim um primeiro passo. Muita gente reagiu de forma tempestuosa e ele se deixou calar. Depois foi a Igreja evangélica que, em 1965, deu mais um passo. Através de um documento, teologicamente bem preparado e politicamente bem pensado, ela preparou a reconciliação entre os alemães por um lado e entre os poloneses, tchecos e russos por outro lado. Anos mais tarde, tornou-se possível através disso aquela política dos tratados sobre o Leste Europeu. Mesmo que se encarem esses tratados de forma crítica, concretamente foram uma

\footnotetext{
${ }^{121}$ KÜNG, Hans. Projeto de Ética Mundial - Uma moral ecumênica em vista da sobrevivência humana. 4. ed. São Paulo: Paulinas, 2003. p. 123.

${ }^{122}$ KÜNG, Hans. Projeto de Ética Mundial - Uma moral ecumênica em vista da sobrevivência humana. 4. ed. São Paulo: Paulinas, 2003. p. 125.

${ }^{123}$ KÜNG, Hans. Projeto de Ética Mundial - Uma moral ecumênica em vista da sobrevivência humana. 4. ed. São Paulo: Paulinas, 2003. p. 126.

${ }^{124}$ KÜNG, Hans. Projeto de Ética Mundial - Uma moral ecumênica em vista da sobrevivência humana. 4. ed. São Paulo: Paulinas, 2003. p. 126.
} 
base capaz de sustentar uma normalização política até que, em 1989, deu-se uma grande virada. ${ }^{125}$

Em síntese, portanto, argumenta Küng que o engajamento das religiões na busca do ethos mundial, por meio do diálogo inter-religioso, contribuiria de duas formas para a paz global: de um lado, preventivamente, uma vez que mitigaria os riscos de eclosão de guerras religiosas; de outro lado, positivamente, ${ }^{126}$ pois as religiões poderiam tomar a iniciativa de resolver conflitos religiosos e não religiosos.

Desta forma, sob o ponto de vista do autor, os líderes religiosos, cientes do relevante papel que as religiões exercem na ordem global, deveriam aderir ao projeto de ética mundial, ${ }^{127}$ tendo em vista que "todas as religiões do mundo devem hoje reconhecer a sua co-responsabilidade pela paz mundial". ${ }^{128}$

O segundo argumento apresentado pelo autor diz respeito à força das religiões na mobilização das pessoas em busca de uma ética mundial. ${ }^{129}$ Nas palavras de Kung:

As religiões falam com uma autoridade absoluta. Esta autoridade não é expressa somente através de palavras e conceitos, doutrinas e dogmas, mas também por meio de símbolos e orações, ritos e festas, e isso de forma racional e emocional. As religiões possuem meios para moldar a existência humana não somente de uma elite intelectual, mas também de amplos segmentos da população. E isso de uma forma historicamente experimentada, culturalmente adequada e individualmente concretizada. ${ }^{130}$

\footnotetext{
${ }^{125}$ KÜNG, Hans. Projeto de Ética Mundial - Uma moral ecumênica em vista da sobrevivência humana. 4. ed. São Paulo: Paulinas, 2003. p. 126.

${ }^{126}$ KÜNG, Hans. Uma Ética Global para a Política e a Economia Mundiais. Petrópolis: Editora Vozes, 1999. p. 194.

${ }^{127}$ KÜNG, Hans. Projeto de Ética Mundial - Uma moral ecumênica em vista da sobrevivência humana. 4. ed. São Paulo: Paulinas, 2003. p. 107.

${ }^{128}$ KÜNG, Hans. Projeto de Ética Mundial - Uma moral ecumênica em vista da sobrevivência humana. 4. ed. São Paulo: Paulinas, 2003. p. 107.

${ }^{129}$ KÜNG, Hans. Projeto de Ética Mundial - Uma moral ecumênica em vista da sobrevivência humana. 4. ed. São Paulo: Paulinas, 2003. p. 109.

${ }^{130}$ KÜNG, Hans. Projeto de Ética Mundial - Uma moral ecumênica em vista da sobrevivência humana. 4. ed. São Paulo: Paulinas, 2003. p. 98.
} 
Assim, as religiões teriam relevante função na promoção do generalizado diálogo desejado por Küng, nos mais diversos níveis, ${ }^{131}$ bem como na propagação da proposta de ética mundial. Complementa o filósofo que, sem o apoio das religiões, "dificilmente se poderia colocar em prática e com amplo apoio a obrigação de uma auto-restrição" - uma vez que o ethos mundial, ao prescrever uma ética normativa, também impõe aos seus adeptos condutas negativas (autorrestrições).

Por fim, o terceiro argumento apresentado pelo autor relaciona-se à capacidade de comprometimento dos religiosos com uma ética prescritiva. Küng, na obra Projeto de Ética Mundial - Uma moral ecumênica em vista da sobrevivência humana, reconhece que "a pessoa sem religião pode levar uma vida verdadeiramente humana e, neste sentido, verdadeiramente moral". ${ }^{132}$ No entanto, sustenta Küng que os não religiosos, em que pese o fato de terem autonomia para seguir normas prescritivas éticas, fundamentam as obrigações éticas em condicionalidades humanas. ${ }^{133}$

\footnotetext{
${ }^{131}$ KÜNG, Hans. Projeto de Ética Mundial - Uma moral ecumênica em vista da sobrevivência humana. 4. ed. São Paulo: Paulinas, 2003. p. 208.

${ }^{132}$ KÜNG, Hans. Projeto de Ética Mundial - Uma moral ecumênica em vista da sobrevivência humana. 4. ed. São Paulo: Paulinas, 2003. p. 93.

${ }^{133}$ Para Küng, nada além do divino, do religioso, pode ser incondicional - nem mesmo a razão. Para o filósofo, algumas questões não podem ser respondidas ou demonstradas racionalmente: "O categórico da existência ética, da incondicionalidade daquilo que se deve fazer, não pode ser fundamentado a partir da pessoa humana, da pessoa multiplamente condicionada. Ele só pode ser fundamentado a partir de um incondicional, a partir de um absoluto, que consegue transmitir um sentido mais geral e que abarca e permeia a pessoa humana e também a natureza humana, sim toda a sociedade humana. E isso só pode ser a realidade última e mais elevada, que não pode ser demonstrada de forma racional, mas aceita numa fé sensata" ((KÜNG, Hans. Projeto de Ética Mundial - Uma moral ecumênica em vista da sobrevivência humana. 4. ed. São Paulo: Paulinas, 2003. p. 96). Complementa o autor: "Das condicionalidades finitas da existência humana, das urgências e necessidades não se pode derivar uma validade incondicional e um assim-deve-ser categórico. Também uma "natureza humana" ou uma "idéia humana" autônoma e abstrata dificilmente pode comprometer pessoas para algo incondicional como instância de fundamentação. Mesmo a "obrigação de sobrevivência da humanidade" dificilmente pode ser demonstrada racionalmente de forma elucidativa. Ante o potencial apocalíptico da técnica atômica e genética, Hans Jonas coloca, com razão, a pergunta metafísica, com a qual a ética não estava confrontada até o momento: por que deve existir uma humanidade? Por que se deve respeitar sua herança genética? Por que, afinal, deve existir vida humana? Com argumentos racionais poderíamos antes fundamentar que a humanidade, do jeito que ela se desenvolveu, não tem mais chances de futuro, mas que, de um ponto de vista moral, está madura para a destruição" (KÜNG, Hans. Projeto de Ética Mundial - Uma moral ecumênica em vista da sobrevivência humana. 4. ed. São Paulo: Paulinas, 2003. p. 94-95). Em resumo, Küng acredita que, por argumentos racionais, é possível defender posições distintas em situações concretas. Assim, na visão do autor, em última instância não seria possível extrair da razão humana um dever moral categórico. Ressaltamos, porém, que importantes filósofos, dentre os quais se destaca Immanuel Kant, defendem a incondicionalidade
} 
Com base em tal posição, Küng, nessa primeira obra sobre o tema "ethos mundial", defende a ideia de que os religiosos têm maior capacidade de comprometimento com éticas prescritivas - e portanto, com o projeto de ética mundial -, uma vez que "somente algo incondicional pode comprometer incondicionalmente" ${ }^{134}$, e as "religiões podem fundamentar suas exigências éticas com uma autoridade bem simples instância humana". ${ }^{135} \mathrm{Na}$ lógica explicitada pelo autor no referido livro, "o categórico da existência ética, da incondicionalidade daquilo que se deve fazer não pode ser fundamentado a partir da pessoa humana, da pessoa multiplamente condicionada", mas

[...] só pode ser fundamentado a partir de um incondicional, a partir de um absoluto, que consegue transmitir um sentido mais geral e que abarca e permeia a pessoa humana e também a natureza humana, sim toda a sociedade humana. E isso só pode ser a realidade última e mais elevada, que não pode ser demonstrada de forma racional, mas aceita numa fé sensata. Isso independe de como é denominada, entendida e interpretada nas diferentes religiões. ${ }^{136}$

Em outras palavras, o autor, na obra Projeto de Ética Mundial - Uma moral ecumênica em vista da sobrevivência humana, apesar de afirmar que não religiosos podem adotar condutas éticas - e, portanto, também são

da razão humana. Sobre o assunto, explica Kant que "o princípio, segundo o qual toda a vontade humana seria uma vontade legisladora universal por meio de todas as suas máximas, se fosse seguramente estabelecido, conviria perfeitamente ao imperativo categórico no sentido de que, exactamente por causa da ideia da legislação universal, ele se não funda em nenhum interesse, e portanto, de entre todos os imperativos possíveis, é o único que pode ser incondicional; ou, melhor ainda, invertendo a proposição: se há um imperativo categórico (i. é uma lei para a vontade de todo o ser racional), ele só pode ordenar que tudo se faça em obediência à máxima de uma vontade que simultaneamente se possa ter a si mesma por objecto como legisladora universal; pois só então é que o princípio prático e o imperativo a que obedece podem ser incondicionais, porque não têm interesse algum sobre que se fundem" (KANT, Immanuel. Fundamentação da Metafísica dos Costumes. Tradução de Paulo Quintela. 1. ed. Lisboa: EDIÇÕES 70, 2007). Para conferir os argumentos sustentados por Kant para a defesa da incondicionalidade da razão, consultar KANT, Immanuel. Fundamentação da Metafísica dos Costumes. Tradução de Paulo Quintela. 1. ed. Lisboa: EDIÇÕES 70, 2007. Por fim, é válido observar que, na interpretação de alguns estudiosos, a tese da incondicionalidade da razão humana defendida por Kant contém uma teologia de fundo. Neste sentido, conferir IRWIN, Tirence. The Development of Ethics- A Historical and Critical Study. Volume III. Oxford: Oxford University Press. p. 135-138.

${ }^{134}$ KÜNG, Hans. Projeto de Ética Mundial - Uma moral ecumênica em vista da sobrevivência humana. 4. ed. São Paulo: Paulinas, 2003. p. 96.

${ }^{135}$ KÜNG, Hans. Projeto de Ética Mundial - Uma moral ecumênica em vista da sobrevivência humana. 4. ed. São Paulo: Paulinas, 2003. p. 97.

${ }^{136}$ KÜNG, Hans. Projeto de Ética Mundial - Uma moral ecumênica em vista da sobrevivência humana. 4. ed. São Paulo: Paulinas, 2003. p. 96. 
destinatários do projeto de ética mundial -, entende que apenas os religiosos seguiriam incondicionalmente uma ética prescritiva, uma vez que o dever de obedecer a estes mandamentos éticos seria fundamentado no incondicional.

É válido, porém, destacar que, nas suas obras seguintes sobre o tema, o autor esclareceu alguns pontos em relação ao terceiro argumento exposto:

a) $\mathrm{o}$ fato de reconhecer nos religiosos maior capacidade de comprometimento com éticas prescritivas - em decorrência de uma predisposição a obedecer, de forma incondicional, a princípios éticos - não significa que Küng negue a capacidade dos não crentes de se guiarem por éticas prescritivas, ou de se identificarem com o ethos mundial. Os não religiosos, para Küng, também podem se manter fiéis a projetos morais. A diferença reside apenas na natureza do fundamento que sustenta o cumprimento destas normas morais: para os religiosos, o fundamento é o incondicional; para os não religiosos, o cumprimento de normas morais tem outros fundamentos (não incondicionais) - pode ser fundamentado, por exemplo, de maneira pragmático-humanista ou com base em alguma filosofia; ${ }^{137}$

b) é indiferente, para o projeto de ética mundial, o fundamento que cada indivíduo elege para cumprir normas morais ${ }^{138}$ - este fundamento pode ser tanto religioso quanto decorrente das diversas tradições éticas

${ }^{137}$ UNISINOS, Revista do Instituto Humanitas Unisinos, edição 240, 2007. p. 3. Disponível em: <http://pt.scribd.com/doc/7991717/6/Hans-Kung-\%E2\%80\%93-Biografia>. Acesso em: 12 de outubro de 2014, às 20:58h.

${ }^{138}$ Importante esclarecer que, ao formular o texto-base da Declaração de Ética Mundial do Parlamento das Religiões Mundiais, Hans Küng se preocupou em investir de fundamento religioso o referido documento, pois a Declaração era voltada "em primeiro lugar para as religiões", uma vez que redigida para o Parlamento das Religiões Mundiais (HOEREN, Jürgen; KÜNG, Hans. Para que um Ethos Mundial? Religião e ética em tempos de globalização - conversando com Jürgen Hoeren. São Paulo: Edições Loyola, 2005. p. 85). Desta forma, o fundamento da ética, para os signatários daquela Declaração, poderia ser objeto de consenso (KÜNG, Hans; SCHMIDT, Helmut. Uma ética mundial e responsabilidades globais - duas declarações. São Paulo: Loyola, 2001. p. 64). No entanto, Hans Küng deixa claro que: a) o que naquela declaração foi afirmado não precisa do fundamento religioso para ser seguido - ou seja, não religiosos, sob outros fundamentos, poderiam adotar as condutas naquela Declaração prescritas; b) o ethos mundial não pressupõe um fundamento religioso, conforme se depreende da Declaração Universal de Responsabilidades Humanas - a qual não faz referência a nenhum fundamento religioso e, ainda assim, é, para Hans Küng, um exemplo de declaração de ética mundial (KUNG, Hans.Uma Ética Global para a Política e a Economia Mundiais. Petrópolis: Editora Vozes, 1999. p. 194). 
existentes. ${ }^{139}$ Os interlocutores do diálogo em busca do ethos mundial não precisam concordar em relação ao fundamento da ética prescritiva que se comprometem a seguir - apenas em relação às normas elementares que, independentemente do fundamento, todo o indivíduo deve observar:

Como são fundamentadas as normas elementares da humanidade é uma questão secundária. Elas podem ser fundamentadas por uma religião ou por determinada filosofia ou também de maneira pragmático-humanista. Para poder conviver de maneira prática, é preciso unificar-se em relação às próprias normas, porém não em relação à sua fundamentação. ${ }^{140}$

Esse segundo posicionamento de Küng foi confirmado na Declaração Universal de Responsabilidades Humanas. ${ }^{141}$ A Declaração, de cuja elaboração Küng participou, não faz alusão a nenhum fundamento religioso e, ainda assim, é citada pelo autor como exemplo de uma declaração de ética mundial. $^{142}$

\subsection{Dos políticos na busca pelo ethos mundial}

Os políticos também são alvo de especial atenção de Küng. ${ }^{143}$ Para o filósofo, a política é fator de expressiva influência na busca da ordem mundial pacífica. Desta forma, pretende o autor que o ethos mundial oriente a política ${ }^{144}$ em busca de um mundo "mais pacífico, mais justo e mais humano". ${ }^{145}$

\footnotetext{
${ }^{139}$ KUNG, Hans.Uma Ética Global para a Política e a Economia Mundiais. Petrópolis: Editora Vozes, 1999. p. 195.

${ }^{140}$ UNISINOS, Revista do Instituto Humanitas Unisinos, edição 240, 2007. p. 3. Disponível em: $<$ http://pt.scribd.com/doc/7991717/6/Hans-Kung-\%E2\%80\%93-Biografia〉. Acesso em: $12 \mathrm{de}$ outubro de 2014, às 21:03h.

${ }^{141}$ O conteúdo da Declaração será abordado detalhadamente no capítulo "As declarações de ética mundial" deste trabalho.

${ }_{142}$ KUNG, Hans. Uma Ética Global para a Política e a Economia Mundiais. Petrópolis: Editora Vozes, 1999. p. 194.

${ }^{143}$ Na obra KUNG, Hans. Uma Ética Global para a Política e a Economia Mundiais. Petrópolis: Editora Vozes, 1999, o autor dedica-se a explicar os motivos pelos quais os políticos e economistas devem aderir ao projeto de ética mundial.

${ }^{144}$ KUNG, Hans. Uma Ética Global para a Política e a Economia Mundiais. Petrópolis: Editora Vozes, 1999. p. 18.

${ }^{145}$ KUNG, Hans. Uma Ética Global para a Política e a Economia Mundiais. Petrópolis: Editora Vozes, 1999. p. 18.
} 
Para comprovar a necessidade de uma consciência ética básica para orientar a política mundial, Küng preocupa-se em demonstrar os problemas causados: a) pela vinculação da política a éticas moralistas e ideais ${ }^{146}$; e b) pela separação total entre política e ética (política realista de interesses nacionalistas ${ }^{147}$ ). Estas duas políticas, para o autor, impedem a convivência pacífica em um contexto mundial pluralista: a primeira, porque elege e impõe princípios éticos não compartilhados por todos; a segunda, porque legitima a adoção de qualquer conduta em prol do interesse do Estado. Com o objetivo de comprovar tal assertiva, Küng analisa dois líderes políticos que, em seu entendimento, figuram como expoentes destas duas visões antagônicas.

Como exemplo de defensor da vinculação da política a éticas moralistas e ideais, Küng cita Woodorow Wilson, presidente dos Estados Unidos, de 1912 a 1921.

Antes de iniciar as críticas à política moralista de Wilson, Küng deixa clara sua admiração pelo ex-presidente americano. O teólogo justifica tal sentimento ao reconhecer que, ao final da Primeira Guerra Mundial, Wilson despendeu verdadeiros esforços em prol de uma nova ordem mundial pacífica ${ }^{148}$, vindo a proclamar, em 08 de janeiro de 1918, com base em quatorze pontos, o programa de paz americano ${ }^{149}$, e a propor, na

\footnotetext{
${ }^{146}$ KUNG, Hans. Uma Ética Global para a Política e a Economia Mundiais. Petrópolis: Editora Vozes, 1999. p. 69.

${ }^{147}$ KUNG, Hans. Uma Ética Global para a Política e a Economia Mundiais. Petrópolis: Editora Vozes, 1999. p. 28.

${ }^{148}$ KUNG, Hans. Uma Ética Global para a Política e a Economia Mundiais. Petrópolis: Editora Vozes, 1999. p. 69.

${ }_{149}$ Para conferir o texto completo da "Mensagem de Paz do Presidente Wilson", com o seu programa de paz dividido em quatorze pontos, e reproduzido em fac-símile de um panfleto americano de 1918, Küng recomenda a obra MANN, G (ed). Propyläen Weltgeschichte. Eine universalgeschichte. Volume IX: Das zwanzigste Jahrhundert. Frankfurt, 1960. p. 120 e seguintes (KUNG, Hans. Uma Ética Global para a Política e a Economia Mundiais. Petrópolis: Editora Vozes, 1999. p. 71). Referência da obra traduzida para o português: SARAIVA, José Hermano Europa e a América do Norte Século XX. In História Universal. Volume IX, Lisboa, Publicações Alfa, 1985.
} 
sequência, aos alemães a celebração de um armistício, oficialmente assinado em 11 de novembro de $1918 .^{150}$

Desses quatorze pontos ${ }^{151}$, Küng extrai "três princípios intimamente

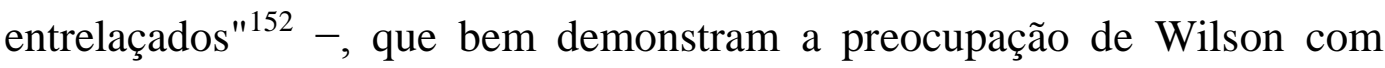
uma ordem mundial pacífica e justa: a) liberdade para todos os povos; b) justiça para todos os povos, no sentido de que todos os povos devem ser respeitados e protegidos de ataques violentos gananciosos; e c) garantia da paz por meio da Liga das Nações. ${ }^{153}$

Além disso, a despeito de reconhecer que o programa de Wilson era demasiado amplo e muitos dos problemas apontados pelo presidente americano permanecem até hoje sem solução ${ }^{154}$, afirma Küng que Wilson obteve êxito na realização de relevantes reformas na política e economia americanas, das quais destaca:

Por meio da redução dos impostos e da reorganização do sistema bancário e creditício a economia americana foi libertada das amarras que a tolhiam; depois veieram as medidas de reforma social, como a proibição do trabalho infantil e a introdução do dia de 8 horas para os ferroviários. ${ }^{155}$

\footnotetext{
${ }^{150}$ KUNG, Hans. Uma Ética Global para a Política e a Economia Mundiais. Petrópolis: Editora Vozes, 1999. p. 69.

151 Küng resume os Quatorze Pontos da proposta de paz de Wilson da seguinte forma: "Inicialmente as exigências básicas (pontos 1-5): negociações e tratados públicos de paz, completa liberdade de navegação, a eliminação máxima possível de todas as barreiras econômicas e o estabelecimento da igualdade nas relações comerciais, redução do potencial armamentista a um mínimo compatível com a segurança nacional, e por último a renúncia a todas as exigências de natureza colonialista, onde os interesses dos povos em questão devem ter o mesmo peso que os justificados interesses dos governos, os direitos jurídicos destes últimos devendo ser submetidos a uma análise. [...] Vem a seguir mais oito exigências (ponto 6-13) referentes aos diversos países, das quais as duas primeiras eram consideradas por Wilson como imprescindíveis: restauração da Bélgica e desocupação dos territórios russos ocupados. Além disso, libertação de todo o território francês e devolução da Alsácia-Lorena à França ("uma injustiça que por quase 50 anos constituiu um desafio à paz mundial"). Deve ser dada ainda aos povos da Áustria-Hungria ocasião para um desenvolvimento autônomo, restauradas a Romênia, a Sérvia e o Montenegro, criado um Estado polonês independente, garantida total independência às partes turcas do Império Otomano; mas também as outras nacionalidades que até agora estiveram sob domínio turco deverão ter a possibilidade de um desenvolvimento autônomo" (KUNG, Hans. Uma Ética Global para a Política e a Economia Mundiais. Petrópolis: Editora Vozes, 1999. p. 72-73).

${ }^{152}$ KUNG, Hans. Uma Ética Global para a Política e a Economia Mundiais. Petrópolis: Editora Vozes, 1999. p. 71.

${ }^{153}$ KUNG, Hans. Uma Ética Global para a Política e a Economia Mundiais. Petrópolis: Editora Vozes, 1999. p. 71.

${ }^{154}$ KUNG, Hans. Uma Ética Global para a Política e a Economia Mundiais. Petrópolis: Editora Vozes, 1999. p. 72 e 73.

${ }^{155}$ KUNG, Hans. Uma Ética Global para a Política e a Economia Mundiais. Petrópolis: Editora Vozes, 1999. p. 73.
} 
Wilson, portanto, na visão de Küng, merece verdadeira admiração por suas iniciativas em prol da paz - as quais levaram o ex-presidente, a receber o Prêmio Nobel da Paz em 1920.

No entanto, em que pesem os esforços de Wilson pós-Primeira Guerra Mundial, Küng ressalta: "não podemos esquecer que, numa mentalidade missionária e com pretensões universalistas, ele terminou elevando a guerra à condição de cruzada pela democracia". ${ }^{156}$ Complementa o teólogo:

Esta mentalidade americana global de cruzada, de motivação moral, foi com razão criticada [...] por todos os realistas. Pois aqui terminam por mostrar-se não apenas os problemas do programa e da política de Wilson, mas também as fraquezas de uma política idealista em si. ${ }^{157}$

Para o autor, uma política moralista pode ter consequências graves observadas não apenas na política de Wilson, mas também em outras situações da história mundial. Küng ressalta que

Numa arrogância moral muitas vezes inconsciente [...] pressupõe-se como evidente que só a própria política e só as próprias instituições seguem os princípios morais; todas as metas egoístas (e situações muitas vezes escandalosas) são camufladas por meio de discursos morais - uma pretensa liderança política com base não só no dever da democracia, liberdade e direitos humanos, mas também na pretensa superioridade da própria civilização e cultura, modelo para o mundo. Entusiasmo cego, intolerância, opressão e até mesmo intervenção militar podem ser a consequência de uma tal presunção moral. ${ }^{158}$

Como exemplos históricos de opressões decorrentes do discurso político moralista, Küng cita a política de expansão americana em Porto Rico, Cuba, Caribe, Guam, Filipinas, justificada com base no "destino manifesto na América, dado pelo próprio Deus (o "God's own country")"159,

\footnotetext{
${ }^{156}$ KUNG, Hans. Uma Ética Global para a Política e a Economia Mundiais. Petrópolis: Editora Vozes, 1999. p. 78.

${ }^{157}$ KUNG, Hans. Uma Ética Global para a Política e a Economia Mundiais. Petrópolis: Editora Vozes, 1999. p. 78.

${ }^{158}$ KUNG, Hans. Uma Ética Global para a Política e a Economia Mundiais. Petrópolis: Editora Vozes, 1999. p. 78.

${ }^{159}$ KUNG, Hans. Uma Ética Global para a Política e a Economia Mundiais. Petrópolis: Editora Vozes, 1999. p. 79.
} 
e as intervenções realizadas por Ronald Reagan e George Herbert Walker

Bush em Granada e no Panamá, respectivamente. ${ }^{160}$

De outro lado, em caso de fracasso das medidas interventivas, a política moralista pode ter como consequência o isolacionismo da nação que se considera eleita ${ }^{161}$ - o que também impede uma ordem mundial integrada.

A despeito de reconhecer os graves problemas que uma política moral idealizante pode causar, Küng nega que a resposta adequada para a ordem global seja a separação total entre a política e a moral.

A corrente política realista, segundo Küng, ganhou força após o fracasso da Liga das Nações na busca da paz mundial, e prega, em síntese, que este mundo é "dominado por interesses opostos e conflitantes"162, e dessa forma, "os princípios morais nunca podem ser perfeitamente postos em prática". ${ }^{163}$ Para os realistas, a paz mundial deve ocorrer por meio de um equilíbrio de poder, de acordo com a seguinte lógica:

A política, seja ela interna ou externa, é essencialmente uma luta pelo poder político, o que significa a dominação de pessoas humanas por outras pessoas humanas. b) Sempre e em toda parte trata-se de conservar, ampliar e manifestar o poder; são estes os três tipos de ação política. c) O critério da política externa do estado nacional, enquanto este existe, tem que ser o interesse nacional; onde a paz é a meta principal de um estado, este está exposto ao membro menos respeitador da comunidade dos estados. d) $\mathrm{Na}$ luta pelo poder é possível uma competição ou alinhamento de interesses. e) Onde os interesses coincidem, uma colaboração entre as nações é possível; onde os interesses colidem, as rivalidades e conflitos entre elas são inevitáveis. f) Para evitar a guerra de todos contra todos faz-se necessária uma diplomacia habilidosa, que aborde a luta pelo poder dentro de uma avaliação razoável dos interesses próprios e alheios, e que prudentemente busque sempre um novo "equilíbrio do poder", um "balance power". g) A paz, portanto, deve, onde for possível, ser garantida pela diplomacia, mas, quando se fizer necessário, também

\footnotetext{
${ }^{160}$ KUNG, Hans. Uma Ética Global para a Política e a Economia Mundiais. Petrópolis: Editora Vozes, 1999. p. 79.

${ }^{161}$ KUNG, Hans. Uma Ética Global para a Política e a Economia Mundiais. Petrópolis: Editora Vozes, 1999. p. 79.

${ }^{162}$ MORGENTHAU, H.J. Politics among Nations. The Struggle for Power and Peace. $3^{\mathrm{a}}$ ed. Nova Iorque, 1948 apud KUNG, Hans. Uma Ética Global para a Política e a Economia Mundiais. Petrópolis: Editora Vozes, 1999. p. 83.

${ }^{163}$ MORGENTHAU, H.J. Politics among Nations. The Struggle for Power and Peace. $3^{\mathrm{a}}$ ed. Nova Iorque, 1948 apud KUNG, Hans. Uma Ética Global para a Política e a Economia Mundiais. Petrópolis: Editora Vozes, 1999. p. 83.
} 
pela ameaça do emprego e da força; a paz não é um presente do céu, como pensam os idealistas e utopistas, mas sim um subproduto da estabilidade e do equilíbrio nas relações de poder entre os povos. ${ }^{164}$

Para melhor explicar a política realista, Küng analisa as estratégias políticas adotadas pelo realista Henry Kissinger, renomado cientista político, professor de Harvard, Assessor de Segurança dos Estados Unidos da América entre os anos de 1969 e 1975, e Ministro do Exterior dos presidentes dos Estados Unidos Nixon e Ford ${ }^{165}$, de 1973 a 1977.

Admirador do alemão Otto von Bismarck-Schönhausen e do francês Cardeal de Richelieu, Kissinger, um dos principais responsáveis pela política externa norte-americana na década de 70, defendia os seguintes pontos: a) os interesses do Estado deviam se sobrepor "a todos os princípios morais"; ${ }^{166}$ b) os estadistas deviam buscar "somente a estabilidade e a segurança através do equilíbrio do poder de todos", ${ }^{167}$ principalmente "entre as superpotências EUA, URSS e República Popular da China (e com isso cuidar efetivamente de garantir o poder sobretudo dos EUA)", ${ }^{168}$ uma vez

\footnotetext{
${ }^{164}$ MORGENTHAU, H.J. Politics among Nations. The Struggle for Power and Peace. $3^{\mathrm{a}}$ ed. Nova Iorque, 1948 apud KUNG, Hans. Uma Ética Global para a Política e a Economia Mundiais. Petrópolis: Editora Vozes, 1999. p. 85.

${ }^{165}$ KUNG, Hans. Uma Ética Global para a Política e a Economia Mundiais. Petrópolis: Editora Vozes, 1999. p. 28.

${ }^{166}$ KUNG, Hans. Uma Ética Global para a Política e a Economia Mundiais. Petrópolis: Editora Vozes, 1999. p. 28. Küng explica que, no livro Diplomacy (KISSINGER, Henry. Diplomacy. New York: Simon \& Schuster Paperbacks, 1994), Kissinger faz menção à necessidade de obediência a alguns valores morais básicos, tais como liberdade e direitos humanos. No entanto, nas palavras de Küng, "se analisado com mais atenção, este livro ao mesmo tempo narrativo e argumentativo de Kissinger é do começo ao fim um eloquente e sedutor ataque ao idealismo americano, manifestamente incorrigível; e ao mesmo tempo uma defesa da política de poder inspirada nos estadistas europeus do passado" (KUNG, Hans. Uma Ética Global para a Política e a Economia Mundiais. Petrópolis: Editora Vozes, 1999. p. 34). Para comprovar o total desrespeito, na prática, a princípios morais que Kissinger pregava, Küng recomenda a leitura de HERSH, Simon M. The Prince of Power. Kissinger in the Nixon White House. Nova Iorque, 1983 e ISAACSON, Walter. Kissinger: a Biography. Nova Iorque, 1992 (KUNG, Hans. Uma Ética Global para a Política e a Economia Mundiais. Petrópolis: Editora Vozes, 1999. p. 40).

${ }^{167}$ KUNG, Hans. Uma Ética Global para a Política e a Economia Mundiais. Petrópolis: Editora Vozes, 1999. p. 32.

${ }^{168}$ KUNG, Hans. Uma Ética Global para a Política e a Economia Mundiais. Petrópolis: Editora Vozes, 1999. p. 32.
} 
que "enormes êxitos foram conseguidos do desprezo, ou mesmo da transgressão das piedosas convicções essenciais de sua época". ${ }^{169}$

Durante os mandatos de Kissinger, Küng reconhece que o cientista político obteve três grandes vitórias: a) "a distensão com a União Soviética através do controle de armamentos (SALT I) em 1969 e do Tratado das Quatro Potências sobre Berlim em 1971"; ${ }^{170}$ b) "a abertura dos EUA para a China, com sua ousada missão secreta a Pequim em 1971"; ${ }^{171}$ c) "a mediação diplomática entre israelenses e árabes durante a Guerra do IomKippur em outubro de 1973 e o tratado de redução de tropas entre Israel e o Egito e entre Israel e a Síria em 1974, condição prévia para o Tratado de Paz entre Israel e o Egito em 1979". ${ }^{172}$ Ocorre que, de outro lado, a subvalorização, por Kissinger, de princípios morais na política trouxe severas consequências, tais como a adoção de "operações e jogadas políticas questionáveis", ${ }^{173}$ das quais destaca Küng: ${ }^{174}$ a) o apoio à violenta ditadura militar do General Pinochet no Chile; b) os ataques ao governo socialista de Portugal e aos partidos comunistas em transformação na Itália e na França, em 1973; c) a má condução da guerra da Indochina, durante a qual os Estados Unidos mostraram "total falta de respeito pelos direitos humanos, pelo direito internacional e pela democracia", ${ }^{175}$ a partir da prática de condutas como bombardeios secretos e invasão do Cambodja, e o bombardeio no período do Natal em Hanói; d) "os atrasos na conclusão de

\footnotetext{
169 KISSINGER, Henry. Diplomacy. New York: Simon \& Schuster Paperbacks, 1994 apud KUNG, Hans. Uma Ética Global para a Política e a Economia Mundiais. Petrópolis: Editora Vozes, 1999. p. 29

${ }^{170}$ KUNG, Hans. Uma Ética Global para a Política e a Economia Mundiais. Petrópolis: Editora Vozes, 1999. p. 31.

${ }^{171}$ KUNG, Hans. Uma Ética Global para a Política e a Economia Mundiais. Petrópolis: Editora Vozes, 1999. p. 31.

${ }^{172}$ KUNG, Hans. Uma Ética Global para a Política e a Economia Mundiais. Petrópolis: Editora Vozes, 1999. p. 31.

${ }^{173}$ KUNG, Hans. Uma Ética Global para a Política e a Economia Mundiais. Petrópolis: Editora Vozes, 1999. p. 41.

${ }^{174}$ KUNG, Hans. Uma Ética Global para a Política e a Economia Mundiais. Petrópolis: Editora Vozes, 1999. p. 41.

${ }^{175}$ KUNG, Hans. Uma Ética Global para a Política e a Economia Mundiais. Petrópolis: Editora Vozes, 1999. p. 41.
} 
paz com o Vienã", ${ }^{176}$ constatados por peritos e observadores americanos, segundo os quais "já em 1969 poderiam ter sido conseguidas condições tão favoráveis para uma solução quanto em 1973". ${ }^{177}$ Nas palavras de Küng,

As consequências da Realpolitik de Nixon e Kissinger são bem conhecidas: protestos sempre mais violentos na opinião pública internacional e americana e mania de perseguição na Casa Branca. Por fim, o caso Watergate, que manifestou um até então inimaginável abuso de poder e energia criminosa na Casa Branca, e que abalou profundamente a confiança da sociedade americana em seu sistema democrático de check and balances. [...] Isto condicionou a omissão na crise do Chipre - provocação grega e depois invasão turca -, com o que ele desagradou tanto a gregos quanto a turcos. E por fim, a 9 de agosto de 1974 , deu-se a renúncia do $37^{\circ}$ presidente dos EUA, pretensamente o primeiro presidente "realista" desde Teddy Roosevelt, de qualquer modo o primeiro a renunciar em face da ameaça de impeachment pelo Congresso. Pelo caso Watergate a América teve de pagar um alto preço em reservas políticas e morais, mesmo que por um ato de perdão de seu sucessor, Gerald Ford, Nixon escapasse à prisão. Ford perdeu as eleições em 1976, Kissinger perdeu o cargo. ${ }^{178}$

Neste mesmo sentido, pronuncia-se Walter Isaacson, o "biógrafo e crítico de Kissinger":

O realismo de Kissinger orientado para o poder, e seu concentrar-se nos interesses nacionais, fracassou porque ele subvalorizou o papel da moralidade. [...] Os reveses que Kissinger teve que engolir como estadista, e os antagonismos que ele despertou como pessoa, devem ser atribuídos à visível amoralidade de seus cálculos geopolíticos. ${ }^{179}$

Em síntese, portanto, Küng, com base no exemplo de Kissinger, afirma que a realpolitik, ao negar uma subordinação da política a princípios morais éticos básicos, obsta uma ordem mundial pacífica.

Assim, conclui Küng que nem a política realista defendida por Richelieu, Bismarck e Henry Kissinger, nem a política idealista defendida

\footnotetext{
${ }^{176}$ KUNG, Hans. Uma Ética Global para a Política e a Economia Mundiais. Petrópolis: Editora Vozes, 1999. p. 41.

${ }^{177}$ KUNG, Hans. Uma Ética Global para a Política e a Economia Mundiais. Petrópolis: Editora Vozes, 1999. p. 41.

${ }^{178}$ KUNG, Hans. Uma Ética Global para a Política e a Economia Mundiais. Petrópolis: Editora Vozes, 1999. p. 42.

${ }^{179}$ ISAACSON, Walter. Kissinger: a Biography. Nova Iorque, 1992 apud KUNG, Hans. Uma Ética Global para a Política e a Economia Mundiais. Petrópolis: Editora Vozes, 1999. p. 45.
} 
por Wilson são suficientes para "garantir a paz na Era policêntrica PósModerna". ${ }^{180}$

Por esses motivos, segundo Küng, para alcançar uma pacífica ordem global, é preciso que os políticos se comprometam com o projeto de ética mundial. O ethos mundial, na opinião do autor, representa uma via intermediária entre o realismo e o idealismo, uma vez que: a) é construído por meio do diálogo dos integrantes da ordem mundial, motivo pelo qual não daria ensejo a um discurso moralista legitimador da opressão ou do isolacionismo; b) ao mesmo tempo, não permite uma política totalmente desvinculada da ética, na qual tudo é permitido em nome do interesse dos Estados.

Vale destacar que, conforme já exposto anteriormente, foi elaborada, pelos representantes de Estados ${ }^{181}$ integrantes do InterAction Council, uma Declaração Universal de Responsabilidades Humanas, na qual foram relacionados princípios éticos globais que deveriam ser seguidos por todos os líderes políticos. Estes princípios, para Küng, se observados pelos líderes políticos, possibilitarão a convivência pacífica entre Estados. O conteúdo dessa Declaração será abordado com mais profundidade no quinto capítulo deste trabalho.

\subsection{Dos economistas na busca pelo ethos mundial}

A preocupação de Küng com a adesão de líderes religiosos e líderes políticos ao seu projeto de ética mundial relaciona-se com a importância que o autor atribui à religião e à política na paz mundial. No entanto, o ethos mundial é voltado a todo e qualquer homem, e deve influenciar também todas as demais áreas da sociedade, uma vez que a ética, sendo prescritiva e universal, "não conhece zonas ou planos livres da ética", e deve ser aplicada a todos os segmentos da sociedade.

\footnotetext{
${ }^{180}$ KUNG, Hans. Uma Ética Global para a Política e a Economia Mundiais. Petrópolis: Editora Vozes, 1999. p. 118.

${ }^{181}$ Para conferir a lista completa de todos os representantes de Estados que assinaram esta declaração, ver nota de rodapé 43 deste trabalho.
} 
Neste sentido, o autor destaca a importância do ethos mundial na fixação da economia dos países e das empresas privadas - sendo certo que, neste caso, o diálogo deveria envolver também representantes destes segmentos, de forma que fosse possível adequar os princípios éticos às necessidades de cada área.

No que diz respeito à economia, Küng explica que a adoção de políticas econômicas também pressupõe uma escolha ética, no sentido de que a função da "atividade econômica é garantir as bases para a vida do homem", ${ }^{182}$ e cada estratégia econômica traz em si "ideais e valores" ${ }^{183}$ que influenciarão a vida dos indivíduos de uma comunidade - logo, "todo o agir econômico possui também dimensões morais". ${ }^{184}$ Complementa Küng que a ética, sendo prescritiva e universal, "sendo categórica e não hipotética, sendo universal e não particular, não conhece zonas ou planos livres da ética". ${ }^{185}$

Para a ordem mundial globalizada na qual vivemos, sustenta Küng a ideia de que se impõe necessário novo paradigma ético-econômico:

Numa época em que a economia efetivamente realizou a epocal mudança de paradigma para uma economia mundial não mais eurocêntrica e sim policêntrica, e quando agora ela tem que adaptar-se de maneira racional às condições globais, existe a necessidade de um novo paradigma da ética econômica que reúna em si a racionalidade econômica e a orientação ética básica. ${ }^{186}$

Neste sentido, ressalta Küng que a economia não pode ser guiada, no contexto atual, nem por uma ética idealista, que apenas estabeleça princípios e não observe a realidade, nem por uma lógica que prescinda de valores éticos, na qual tudo é legitimado na busca pelo lucro.

\footnotetext{
${ }^{182}$ KUNG, Hans. Uma Ética Global para a Política e a Economia Mundiais. Petrópolis: Editora Vozes, 1999. p. 408.

${ }^{183}$ KUNG, Hans. Uma Ética Global para a Política e a Economia Mundiais. Petrópolis: Editora Vozes, 1999. p. 408.

${ }^{184}$ KUNG, Hans. Uma Ética Global para a Política e a Economia Mundiais. Petrópolis: Editora Vozes, 1999. p. 406.

${ }^{185}$ KUNG, Hans. Uma Ética Global para a Política e a Economia Mundiais. Petrópolis: Editora Vozes, 1999. p. 406.

${ }^{186}$ KUNG, Hans. Uma Ética Global para a Política e a Economia Mundiais. Petrópolis: Editora Vozes, 1999. p. 398.
} 
De um lado, a economia idealista, que se preocupa exclusivamente com a motivação puramente moral e com a boa finalidade,

[...] não leva adequadamente em conta a ordem econômica dada e o que é concretamente viável num sistema altamente complexo. Uma tal ética econômica de intenções idealistas costuma em princípio, ou pelo menos em casos concretos, desacreditar a busca do lucro como sendo de antemão imoral. Contra isto deve se dizer o seguinte: Levantar para o grande público exigências morais que carecem de toda a racionalidade econômica, que portanto não levam em conta as leis próprias da economia, não é moral e sim moralismo. ${ }^{187}$

Desta forma, a economia moralista não é adequada a essa nova ordem global, pois, ao considerar apenas as motivações morais das condutas, não admitiria que "buscar os interesses próprios e procurar o lucro, quando não prejudica bens mais elevados, é legítimo". ${ }^{188}$ Complementa o autor que, ao observar apenas as motivações morais das condutas, sem levar em conta os resultados econômicos, a política econômica moralista poderia se mostrar ineficiente:

Também na economia, "bem intencionado" é o contrário do bom. Uma tal ética de intenções, contrária às leis econômicas, quando analisada de perto, não é ética mas sim romantismo, um desejo mais ou menos piedoso. Precisamente nesta era da globalização vale que bons motivos ainda não garantem uma boa atividade econômica. Da arte da atividade econômica bem sucedida faz parte avaliar não apenas os efeitos intencionados (como, por exemplo, aumento da produção), mas também os efeitos não intencionados mas que muitas vezes são extremamente graves (por exemplo, a reação dos sindicatos, a poluição ambiental). Quem apenas deseja agir bem sem levar em conta as possíveis más consequências e efeitos colaterais, está agindo de maneira irresponsável ou mesmo culposa, mesmo que no caso de fracasso ele goste de lançar a culpa sobre os outros ou sobre as circunstâncias. Freqüentes vezes um falso idealismo tem confundido empresários caridosos e de mentalidade social. Para um agir econômico responsável e que leve a bons resultados vale: $\mathrm{O}$ que importa não são unicamente os motivos, mas também os resultados. ${ }^{189}$

\footnotetext{
${ }^{187}$ KUNG, Hans. Uma Ética Global para a Política e a Economia Mundiais. Petrópolis: Editora Vozes, 1999. p. 405.

${ }^{188}$ KUNG, Hans. Uma Ética Global para a Política e a Economia Mundiais. Petrópolis: Editora Vozes, 1999. p. 405.

${ }^{189}$ KUNG, Hans. Uma Ética Global para a Política e a Economia Mundiais. Petrópolis: Editora Vozes, 1999. p. 405.
} 
De outro lado, uma ética de resultados sem princípios pode levar ao "libertinismo grosseiro e ao capitalismo desenfreado" ${ }^{190}$, no qual

o lucro santifica todos os meios se necessário, também os meios imorais, como quebra da confiança, logro e mentira. A busca do lucro, que pode ser moralmente justificada, é elevada aqui à condição de um dogmático "princípio do lucro", ou mesmo de um "princípio da maximação do lucro". ${ }^{191}$

Assim, mostra-se necessária a adoção de normas morais para a economia, que imponham ao agir econômico responsabilidade ética, a fim de proteger a exploração econômica de indivíduos, visto que "sem esses valores não são possíveis as relações comerciais estáveis e uma comunidade mundial capaz de sobreviver". ${ }^{192}$ Complementa Küng:

O primado da ética, de qualquer forma, não vale apenas, como às vezes afirmam os defensores da (já refutada) "teoria econômica da moral", para as condições de pequenos grupos (família, aldeia), que podem ser abrangidos com um olhar, mas também - de maneira análoga - no plano da grande e anônima sociedade de divisão do trabalho, que, aliás, em todos os planos de decisão, é sempre constituída por pequenos grupos e indivíduos. Uma tal divisão deixa de lado também todo o espectro das instituições intermediárias, que exercem uma função mediadora entre a esfera privada e mega estruturas sociais (associações profissionais, grupos industriais, sindicatos). ${ }^{193}$

Neste sentido, o ethos mundial, em sua qualidade de consciência ética básica, seria, para Küng, a melhor alternativa na fixação de políticas econômicas, uma vez que: a) de um lado, por ser mínima (não minimalista) e decorrente do diálogo ${ }^{194}$ entre representantes de todos os segmentos

\footnotetext{
${ }^{190}$ KUNG, Hans. Uma Ética Global para a Política e a Economia Mundiais. Petrópolis: Editora Vozes, 1999. p. 406.

${ }^{191}$ KUNG, Hans. Uma Ética Global para a Política e a Economia Mundiais. Petrópolis: Editora Vozes, 1999. p. 406.

${ }^{192}$ KUNG, Hans. Uma Ética Global para a Política e a Economia Mundiais. Petrópolis: Editora Vozes, 1999. p. 430.

${ }^{193}$ KUNG, Hans. Uma Ética Global para a Política e a Economia Mundiais. Petrópolis: Editora Vozes, 1999. p. 409.

${ }^{194}$ Vale destacar: Küng menciona o fato de que a necessidade de se estabelecerem princípios mínimos para guiar a economia já foi reconhecida internacionalmente na elaboração de duas declarações: a) a Declaração Interfaith, que consiste em um código de ética sobre o comércio internacional para cristãos, muçulmanos e judeus, "elaborada sob a proteção do Príncipe Filipe, Duque de Edinburgo; de Hassan Bin Talal, Príncipe herdeiro da Jordânia; e de Sir Evelyn de Rothschild, no período de 1988 (Windsor) a 1993 (Amã)" (KUNG, Hans. Uma Ética Global para a Política e a Economia Mundiais. Petrópolis: Editora Vozes, 1999. p. 429); b) a Declaração
} 
econômicos, não imporia aos economistas um projeto ético utópico e em desacordo com a realidade, o qual não observasse as normas do mercado econômico e os resultados das estratégias adotadas; b) de outro lado, seria

Principles for Business - na qual constam relacionados princípios éticos que deveriam ser observados nas tomadas de decisões econômicas -, elaborada por The Caux Round Table, grupo internacional criado em 1986 por "Frederick Philips (antigo Presidente da Philips Eletronics) e por Oliverd Giscard d'Estaing (Vice-Presidente do INSEAD), levado adiante por Ryozaburo Kaku (Diretor-Presidente da Canon Inc.) e concluído em 1994 com numerosas participações das lideranças econômicas da Europa, Japão e Estados Unidos" (KUNG, Hans. Uma Ética Global para a Política e a Economia Mundiais. Petrópolis: Editora Vozes, 1999. p. 430). Dentre os princípios relacionados nestas duas declarações - ambas, vale explicar, voltadas para os empresários -, Küng destaca: a) a responsabilidade das empresas não apenas com seus acionistas, mas também com todos aqueles que para estas contribuem, tais como clientes, empregados, fornecedores, financiadores, a comunidade, os governos locais e nacionais; b) a responsabilidade dos empresários em relação aos seus empregados e subordinados, por meio da adoção das seguintes posturas: b.1) levar a sério os interesses dos trabalhadores; b.2) negociar de maneira honesta, em caso de conflito, com seus empregados; b.3) fornecer condições para o empregado obter as melhores condições de vida possíveis; b.4) preocupar-se com o emprego de pessoas com deficiência, em funções nas quais estas possam ser úteis; b.5) mostrar-se sensível aos graves problemas de desemprego ligados a decisões comerciais, e contribuir com os governos, grupos de empregadores e outras organizações, a fim de superar estas dificuldades; b.6) não discriminar seus empregados; c) manter o comprometimento das empresas em agir com justiça, respeito, fidelidade, honestidade e transparência em toda e qualquer operação econômica, em relação a seus acionistas, clientes, empregados, fornecedores, financiadores, a comunidade, os governos locais e nacionais (KUNG, Hans. Uma Ética Global para a Política e a Economia Mundiais. Petrópolis: Editora Vozes, 1999. p. 429). Não abordaremos, no presente trabalho, o conteúdo dessas Declarações. Para conferir os princípios econômicos relacionados na Declaração Interfaith, ver British-North American Research Association. An interfaith declaration. A code of ethics on internataional business for Christians, Muslins and Jews. London: Grosvenor Gardens, 1998. Para conferir os princípios econômicos relacionados na Declaração Principles For Business, ver Caux Round Table. Principles For Business. Haia, 1994. Vale ainda esclarecer que, para Küng, estas declarações não esgotaram todos os pontos econômicos que devem ser objeto de debate. Küng sugere, a título de exemplo, que sejam discutidos, em novas reuniões internacionais, pontos como: a) responsabilidades das empresas com a formação e especialização dos seus trabalhadores; b) responsabilidades dos empregados perante a empresa (KUNG, Hans. Uma Ética Global para a Política e a Economia Mundiais. Petrópolis: Editora Vozes, 1999. p. 444). Em especial no que diz respeito à conduta ética dos empresários, Küng também afirma que a não observância de princípios éticos traz resultados negativos para as empresas, pois "1) Mais cedo ou mais tarde o conflito com a lei penal ameaça também aqueles que julgam sempre poder escapar incólumes; 2) Quando as transgressões passam a ser mais frequentes, sempre transpira o clamor por regulamentações legais, o que então passa a ser exigido pela economia, ou mais adiante pelos bancos; 3) O sistema creditício não gosta de conceder créditos a quem não merece crédito [...]; 4) Toda firma também depende de mais crédito além do crédito meramente financeiro: Ela tem necessidade de crédito no sentido de credibilidade, e isto sob múltiplos aspectos: para os membros da empresa e para aqueles que se encontram em processo de formação, que gostariam de trabalhar em uma firma de renome; para os moradores e a comunidade local, de cuja boa vontade a firma depende; para os financiadores, fornecedores e fregueses, que não gostam de confiar em pessoas que não dispõem de crédito moral; para o grande público, perante o qual nenhuma firma pode se dar ao luxo de ter uma imagem ruim; 5) As leis impõem sanções externas, mas a consciência ética impõe também sanções internas: a má consciência não pode sem mais nem menos ser reprimida, ela se faz ouvir" (KUNG, Hans. Uma Ética Global para a Política e a Economia Mundiais. Petrópolis: Editora Vozes, 1999. p. 464). 
uma alternativa à desvinculação absoluta da moral e da economia, e imporia limites morais ao mercado e à busca do lucro. ${ }^{195}$

${ }^{195}$ KUNG, Hans. Uma Ética Global para a Política e a Economia Mundiais. Petrópolis: Editora Vozes, 1999. p. 408. 


\section{As declarações de ética mundial}

Conforme já exposto anteriormente, Hans Küng, na sua proposta de ética mundial, sustenta a ideia de que, para possibilitar a convivência pacífica global, as sociedades devem agir de acordo com princípios éticos universais mínimos, extraídos do amplo e constante diálogo intercultural. Desta forma, o projeto de ethos mundial pode ser classificado como metodológico construtivista, no sentido de que indica o método pelo qual deverão ser encontrados estes princípios mínimos. ${ }^{196}$

Ocorre que a metodologia sugerida por Hans Küng já foi aplicado na elaboração de duas declarações de ética mundial, das quais o autor participou: a Declaração de Ética Mundial do Departamento das Religiões Mundiais e a Declaração Universal das Responsabilidades Humanas. Assim, é possível afirmar que, de certa forma, já existe um esboço do conteúdo do ethos mundial da humanidade, sendo certo que estas duas declarações, na opinião de Küng, representam apenas o começo de um processo dialógico intercultural ${ }^{197}$ - que deve ser constante e presente em todos os segmentos da sociedade ${ }^{198}$-, motivo pelo qual devem ser aperfeiçoadas, a fim de se tornarem mais precisas e concretas. ${ }^{199}$

Em razão do exposto, cumpre a nós analisar, neste trabalho, o processo de elaboração e o conteúdo destas duas declarações, com o objetivo de melhor compreender a proposta de ética mundial de Hans Küng.

\footnotetext{
196 José Rubio Carracedo define ética construtivista metodológica como aquela decorrente do "diálogo entre sujeitos competentes e imparciais, dispostos a cooperar comunicativamente (...), com o intuito de buscar, ou ao menos tentar, uma solução para o conflito de interesses (...), mediante razões válidas (...), aceitas por aqueles que participam do diálogo real" (CARRACEDO, José Rubio. Ética constructivista y autonomía personal. Madrid: Tecnos, 1992. p. 250). Para conferir de forma detalhada a concepção de ética construtivista metodológica, ver CARRACEDO, José Rubio. Ética constructivista y autonomía personal. Madrid: Tecnos, 1992.

${ }^{197}$ KÜNG, Hans; SCHMIDT, Helmut. Uma ética mundial e responsabilidades globais - duas declarações. São Paulo: Loyola, 2001. p. 48.

${ }^{198}$ KÜNG, Hans. Projeto de Ética Mundial - Uma moral ecumênica em vista da sobrevivência humana. 4. ed. São Paulo: Paulinas, 2003. p. 206

${ }_{199}$ KÜNG, Hans; SCHMIDT, Helmut. Uma ética mundial e responsabilidades globais - duas declarações. São Paulo: Loyola, 2001. p. 48.
} 


\subsection{A Declaração do Parlamento das Religiões do Mundo}

A Declaração do Parlamento das Religiões do Mundo, cujo anteprojeto foi elaborado por Küng, pode ser traduzida, na opinião do autor, como uma primeira tentativa de mapeamento do ethos mundial da humanidade $^{200}$ - ou, mais precisamente, do ethos mundial das religiões, uma vez que apenas representantes religiosos participaram do diálogo.

De acordo com o que consta narrado na obra Uma ética mundial e responsabilidades globais - duas declarações ${ }^{201}$, Küng foi oficialmente convidado a elaborar o projeto da Declaração a ser discutida e assinada pelo Parlamento das Religiões Mundiais em 27 de fevereiro de 1992, por intermédio do diretor executivo da referida organização internacional, Daniel Gómez-Ibañes.

Küng então iniciou os trabalhos de preparação do texto, e esboçou um preâmbulo da declaração. Na elaboração do preâmbulo, o filósofo já trazia em mente alguns pontos importantes que deveriam ser observados na declaração:

a) em primeiro lugar, "era indispensável - contra o pano de fundo do mundo atual - fazer uma clara distinção entre o nível ético e o puramente legal ou político, e ao mesmo tempo dar uma definição precisa do termo ética mundial"; 202

b) em segundo lugar, a Declaração não poderia:

b.1) consistir em mera repetição da Declaração de Direitos Humanos. Neste sentido, explica Küng:

Se as religiões, essencialmente, apenas repetissem enunciados da Declaração de Direitos Humanos da ONU, ela seria dispensável; contudo, uma ética é mais do que direitos. E, certamente, tal declaração sobre uma ética não escaparia à acusação feita especialmente pelas religiões indianas de que se tratava de um documento ocidental. No entanto, se uma declaração sobre uma ética

\footnotetext{
${ }^{200}$ HOEREN, Jürgen; KÜNG, Hans. Para que um Ethos Mundial? Religião e ética em tempos de globalização - conversando com Jürgen Hoeren. São Paulo: Edições Loyola, 2005, p. 29.

${ }^{201}$ KÜNG, Hans; SCHMIDT, Helmut. Uma ética mundial e responsabilidades globais - duas declarações. São Paulo: Loyola, 2001.

${ }^{202}$ KÜNG, Hans; SCHMIDT, Helmut. Uma ética mundial e responsabilidades globais - duas declarações. São Paulo: Loyola, 2001. p. 60.
} 
mundial forneceria suporte ético à Declaração de Direitos Humanos da ONU, que é tão desprezada, violada e evitada, Tratados, leis, acordos são apenas observados quando há uma subjacente vontade ética de observá-los; ${ }^{203}$

\section{b.2) basear-se em uma teoria ocidental moderna específica; ${ }^{204}$}

b.3) traduzir-se em "um sermão moral casuístico"; 205

\section{Complementa o autor:}

Se as religiões [...] quisessem fazer enunciados impositivos para cada caso difícil possível [...] elas seriam rejeitadas a priori por muitas pessoas hoje e certamente não poderiam produzir um consenso. [...] Não obstante, uma declaração sobre uma ética mundial não deveria hesitar em fazer enunciados claros mesmo sobre verdades e exigências incômodas - como o respeito pela vida - e não deveria deixar de lado a esfera sexual; ${ }^{206}$

\section{b.4) confundir-se com um "tratado filosófico" ${ }^{207}$, pois "uma} declaração sobre ética mundial não deve dirigir-se apenas a intelectuais e pessoas instruídas". ${ }^{208}$ Apesar disso,

Uma declaração sobre ética mundial deveria absorver prontamente os estímulos fornecidos pela filosofia e deveria ser formulada de tal modo que os filósofos - e também agnósticos e ateístas - pudessem aceitá-la, mesmo que não compartilhassem o fundamento transcendente de tal declaração; ${ }^{209}$

\section{b.5) transformar-se em uma simples "proclamação religiosa} entusiástica", uma vez que:

Se as religiões simplesmente invocam a consciência cósmica, a harmonia global, a criatividade espiritual, a unidade universal, o amor abrangente e uma visão espiritual de um mundo melhor, ou celebram em hinos a mãe terra, deixando de encarar com seriedade suficiente a

\footnotetext{
203 KÜNG, Hans; SCHMIDT, Helmut. Uma ética mundial e responsabilidades globais - duas declarações. São Paulo: Loyola, 2001. p. 60.

${ }^{204}$ KÜNG, Hans; SCHMIDT, Helmut. Uma ética mundial e responsabilidades globais - duas declarações. São Paulo: Loyola, 2001. p. 60.

${ }^{205}$ KÜNG, Hans; SCHMIDT, Helmut. Uma ética mundial e responsabilidades globais - duas declarações. São Paulo: Loyola, 2001. p. 60.

${ }^{206}$ KÜNG, Hans; SCHMIDT, Helmut. Uma ética mundial e responsabilidades globais - duas declarações. São Paulo: Loyola, 2001. p. 62.

207 KÜNG, Hans; SCHMIDT, Helmut. Uma ética mundial e responsabilidades globais - duas declarações. São Paulo: Loyola, 2001. p. 62.

${ }^{208}$ KÜNG, Hans; SCHMIDT, Helmut. Uma ética mundial e responsabilidades globais - duas declarações. São Paulo: Loyola, 2001. p. 62.

${ }^{209}$ KÜNG, Hans; SCHMIDT, Helmut. Uma ética mundial e responsabilidades globais - duas declarações. São Paulo: Loyola, 2001. p. 62.
} 
realidade econômica, política e social da atual sociedade industrial altamente complexa, elas estão se alienando da realidade ${ }^{210}$;

c) Em terceiro lugar, a declaração de ética mundial das religiões deveria:

c.1) ser capaz de garantir um consenso, buscando-se sempre "unanimidade moral, e não apenas unanimidade numérica"; ${ }^{211}$ c.2) ser autocrítica ${ }^{212}$, e endereçada não apenas ao mundo, mas também e primariamente aos seus signatários, pois o frequente fracasso das religiões "em estabelecer a paz, não deveria ser encoberto, mas afirmado inequivocamente". ${ }^{213}$ Assim, "a declaração deveria ter o caráter não de gentil confirmação, mas de construtiva provocação"; ${ }^{214}$

c.4) estar vinculada à realidade; ${ }^{215}$

c.5) ser compreensível a $\operatorname{todos}^{216}$, e expressa "numa linguagem que pelo menos o leitor comum entenda e que também possa ser traduzida para outras línguas"; ${ }^{217}$

c.6) ter um fundamento religioso ${ }^{218}$, na medida em que "para as religiões, uma ética tem um fundamento religioso". ${ }^{219}$ Esta declaração, porém, não poderia fazer menção a Deus, caso contrário, "teria sido necessário deixar de fora o budismo,

\footnotetext{
${ }^{210}$ KÜNG, Hans; SCHMIDT, Helmut. Uma ética mundial e responsabilidades globais - duas declarações. São Paulo: Loyola, 2001. p. 62.

${ }^{211}$ KÜNG, Hans; SCHMIDT, Helmut. Uma ética mundial e responsabilidades globais - duas declarações. São Paulo: Loyola, 2001. p. 63.

${ }^{212}$ KÜNG, Hans; SCHMIDT, Helmut. Uma ética mundial e responsabilidades globais - duas declarações. São Paulo: Loyola, 2001. p. 63.

${ }^{213}$ KÜNG, Hans; SCHMIDT, Helmut. Uma ética mundial e responsabilidades globais - duas declarações. São Paulo: Loyola, 2001. p. 63.

${ }^{214}$ KÜNG, Hans; SCHMIDT, Helmut. Uma ética mundial e responsabilidades globais - duas declaraçães. São Paulo: Loyola, 2001. p. 63.

${ }^{215}$ KÜNG, Hans; SCHMIDT, Helmut. Uma ética mundial e responsabilidades globais - duas declarações. São Paulo: Loyola, 2001. p. 63.

${ }^{216}$ KÜNG, Hans; SCHMIDT, Helmut. Uma ética mundial e responsabilidades globais - duas declaraçães. São Paulo: Loyola, 2001. p. 63.

${ }^{217}$ KÜNG, Hans; SCHMIDT, Helmut. Uma ética mundial e responsabilidades globais - duas declarações. São Paulo: Loyola, 2001. p. 63.

${ }^{218}$ Abordamos a questão do fundamento religioso no item 4.1. deste trabalho - em especial na nota de rodapé 138.

${ }^{219}$ KÜNG, Hans; SCHMIDT, Helmut. Uma ética mundial e responsabilidades globais - duas declarações. São Paulo: Loyola, 2001. p. 65.
} 
uma das grandes religiões do mundo" ${ }^{220}$, pois para os budistas "os deuses não são a Realidade Última, o Fundamento Absoluto e Propósito Primeiro". ${ }^{221}$

Com base nestas diretrizes, Küng elaborou o preâmbulo da Declaração. Tal preâmbulo foi disponibilizado não apenas para os integrantes do Conselho responsável pela promoção do encontro a ser realizado pelo Parlamento das Religiões Mundiais, mas também foi enviado, pelo filósofo, "a vários estudiosos competentes de diversas religiões do mundo, [...] correspondentes da Europa à América, da África Central a Bangladesh"222, e debatido em palestras realizadas em vários locais, tais como a Conferência Mundial das Religiões para a Paz, em Mainz; o Congresso Mundial de Credo, em Londres; a Associação Internacional para a Liberdade Religiosa, em Hamburgo; o Instituto Shalom Hartman, em Jerusalém; o Fórum de Economia Mundial, em Davos; o Templo do Entendimento e a ONU, em Nova Iorque. ${ }^{223}$

Em 14 de julho de 1992, o primeiro projeto da Declaração

[...] estava pronto e foi imediatamente enviado aos peritos ${ }^{224}$ para comentários e correções. Sem exceção, ele teve grande aprovação; sua estrutura básica permaneceu inalterada, mas foi consideravelmente melhorado por numerosas sugestões de detalhes. Em 12 de outubro de 1992 , o segundo anteprojeto aperfeiçoado estava pronto. ${ }^{225}$

O anteprojeto elaborado por Küng foi enviado ao Conselho do Segundo Parlamento das Religiões Mundiais em Chicago "e tornado

\footnotetext{
${ }^{220}$ KÜNG, Hans; SCHMIDT, Helmut. Uma ética mundial e responsabilidades globais - duas declarações. São Paulo: Loyola, 2001. p. 65.

${ }^{221}$ KÜNG, Hans; SCHMIDT, Helmut. Uma ética mundial e responsabilidades globais - duas declarações. São Paulo: Loyola, 2001. p. 65. Para conferir com mais profundidade a relação dos budistas (e das demais religiões) com o divino, ver KÜNG, Hans. Religiões do Mundo. Em busca dos pontos comuns. São Paulo: Editora Verus, 2004.

222 KÜNG, Hans; SCHMIDT, Helmut. Uma ética mundial e responsabilidades globais - duas declarações. São Paulo: Loyola, 2001. p. 57.

${ }^{223}$ KÜNG, Hans; SCHMIDT, Helmut. Uma ética mundial e responsabilidades globais - duas declarações. São Paulo: Loyola, 2001. p. 57.

${ }^{224}$ Para conferir os peritos responsáveis pela elaboração desta Declaração, ver nota de rodapé 44.

225 KÜNG, Hans; SCHMIDT, Helmut. Uma ética mundial e responsabilidades globais - duas declarações. São Paulo: Loyola, 2001. p. 57.
} 
acessível a todos os membros do corpo de diretores". ${ }^{226}$ Por fim, "vários cardeais e bispos estudaram atentamente o projeto, como também eruditos e monges de religiões não cristãs". 227

Em julho de 1993 o anteprojeto foi aprovado pela diretoria do Parlamento das Religiões Mundiais e, após pontuais ajustes, levado à deliberação no Conselho do Segundo Parlamento das Religiões Mundiais. No entanto, Küng destaca o fato de que, para sua infelicidade, ao contrário do que havia sido acordado inicialmente, o projeto não foi enviado com antecedência a todos os integrantes do Parlamento, "mas apenas a cerca de duzentos delegados das várias religiões e também - com um embargo logo derrubado - à imprensa". ${ }^{228}$ Por esse motivo, na reunião do Segundo Parlamento das Religiões Mundiais, para a qual foram convidados todos os delegados do Parlamento, o conteúdo da declaração de ética mundial não mais podia ser alterado - o que levou alguns representantes de religiões mundiais a fazerem objeções a determinadas afirmações constantes do texto:

Contrariando o acordo original, o Conselho retivera a Declaração Para uma Ética Mundial" para poder apresentá-la no fim como uma conclusão efetiva - sobretudo com a mídia em vista. Ela fora fornecida à Assembleia, mas com a condição de que agora só poderia ser discutida, mas não alterada. Mas isso causou objeções (compreensíveis em apenas alguns aspectos) por parte dos que rejeitaram o próprio procedimento (que absolutamente não fora explicado aos delegados) e encorajou os que tinham problemas com pontos individuais do conteúdo. ${ }^{229}$

A despeito dessa falha metodológica, reconhecida por Küng, o autor entende que o resultado da reunião do Parlamento das Religiões Mundiais foi positivo, pois as objeções feitas ao texto - mais detalhadamente

\footnotetext{
${ }^{226}$ KÜNG, Hans; SCHMIDT, Helmut. Uma ética mundial e responsabilidades globais - duas declarações. São Paulo: Loyola, 2001. p. 58.

${ }^{227}$ KÜNG, Hans; SCHMIDT, Helmut. Uma ética mundial e responsabilidades globais - duas declarações. São Paulo: Loyola, 2001. p. 58.

${ }^{228}$ KÜNG, Hans; SCHMIDT, Helmut. Uma ética mundial e responsabilidades globais - duas declaraçães. São Paulo: Loyola, 2001. p. 59.

${ }^{229}$ KÜNG, Hans; SCHMIDT, Helmut. Uma ética mundial e responsabilidades globais - duas declarações. São Paulo: Loyola, 2001. p. 70.
} 
abordadas a seguir - não se referiam ao cerne da Declaração. ${ }^{230}$ Além disso, todos os presentes concordaram em relação à "necessidade e utilidade de uma Declaração para uma Ética Mundial". ${ }^{231}$ Por este motivo, o filósofo entende que a Declaração pode ser vista como exemplo de iniciativa em busca do ethos mundial.

Isto posto, passemos a analisar o conteúdo da Declaração da Ética Mundial do Parlamento das Religiões Mundiais, assinada por representantes de "todas as religiões possíveis". 232

A Declaração é organizada da seguinte forma: a) Preâmbulo; b) Parte I: "Não há nova ordem mundial sem uma ética mundial"; c) Parte II: "O desafio básico: todo ser humano deve ser tratado de forma humana"; d) Parte III: "Quatro Preceitos Inamovíveis"; e) Parte IV: "Mudança de consciência".

No Preâmbulo do documento, em síntese, afirma-se: 1) a existência de conflitos mundiais decorrentes de fanatismo religioso; 2) a existência de valores fundamentais comuns às doutrinas e religiões, os quais poderiam servir de base para uma ética mundial; 3) a responsabilidade dos religiosos na promoção da paz mundial e na adoção de posturas em prol do respeito à vida, à dignidade, à individualidade e às diferenças, e em favor da igualdade de direitos entre homens e mulheres.

Na Parte I da Declaração, destaca-se a necessidade de uma ética mundial para reger esta nova ordem global pacífica, consistente em "valores obrigatórios vigentes, parâmetros inamovíveis e atitudes pessoais básicas"233, extraídos de um "consenso fundamental"234 entre todas as

\footnotetext{
${ }^{230}$ KÜNG, Hans; SCHMIDT, Helmut. Uma ética mundial e responsabilidades globais - duas declarações. São Paulo: Loyola, 2001. p. 70.

231 KÜNG, Hans; SCHMIDT, Helmut. Uma ética mundial e responsabilidades globais - duas declarações. São Paulo: Loyola, 2001. p. 74.

${ }^{232}$ Para conferir todos os signatários da Declaração da Ética Mundial do Parlamento das Religiões Mundiais, conferir nota de rodapé 44.

233 KÜNG, Hans; SCHMIDT, Helmut. Uma ética mundial e responsabilidades globais - duas declarações. São Paulo: Loyola, 2001. p. 19.

${ }^{234}$ KÜNG, Hans; SCHMIDT, Helmut. Uma ética mundial e responsabilidades globais - duas declarações. São Paulo: Loyola, 2001. p. 19.
} 
religiões. Não obstante, ressalta-se que "sem um consenso fundamental na ética, cedo ou tarde toda a comunidade vê-se ameaçada pelo caos ou por uma ditadura, e as pessoas, como indivíduos, perderão a esperança". ${ }^{235}$

$\mathrm{Na}$ Parte II da Declaração, assevera-se um princípio básico compartilhado entre todas as religiões: "todo ser humano tem se ser tratado de forma humana". ${ }^{236}$ Em outras palavras, "todo ser humano - sem distinção de idade, sexo, raça, cor, capacidade física ou intelectual, língua, religião, convicção política, origem nacional ou social - é dotado de dignidade intocável e inalienável [...] e deve ser fim, jamais mero meio". ${ }^{237}$

A vedação ao tratamento desumano, vale acrescentar, também pode ser extraída da "regra de ouro presente e preservada há milênios em muitas tradições religiosas e éticas da humanidade: não faze ao outro o que não queres que façam a ti. Ou, formulada de modo positivo: faze aos outros o que queres que façam também a ti." 238

Neste sentido, assevera-se o comprometimento dos religiosos na promoção de uma mudança de consciência em prol da prática deste mandamento:

Estamos cientes de que as religiões não podem resolver os problemas ecológicos, econômicos, políticos e sociais desta Terra. É provável, porém, que elas possam alcançar o que planos econômicos, programas políticos ou regramentos jurídicos não podem alcançar por si sós: a atitude interior, a mentalidade como um todo. [...] Nós, como pessoas de orientação religiosa ou espiritual, queremos comprometer-nos de maneira especial de maneira especial com essa renovação - cientes que as forças espirituais das religiões são capazes de proporcionar às pessoas, ao longo de suas vidas, uma confiança fundamental, um horizonte de sentido, parâmetros últimos e uma pátria espiritual. Por certo, as religiões só tem credibilidade para fazer tal coisa quando elas próprias suplantam os conflitos a que dão origem, quando superam reciprocamente a superioridade, a desconfiança, os preconceitos e as

\footnotetext{
${ }^{235}$ KÜNG, Hans; SCHMIDT, Helmut. Uma ética mundial e responsabilidades globais - duas declarações. São Paulo: Loyola, 2001. p. 19.

${ }^{236}$ KÜNG, Hans; SCHMIDT, Helmut. Uma ética mundial e responsabilidades globais - duas declarações. São Paulo: Loyola, 2001. p. 19.

${ }^{237}$ KÜNG, Hans; SCHMIDT, Helmut. Uma ética mundial e responsabilidades globais - duas declarações. São Paulo: Loyola, 2001. p. 19.

${ }^{238}$ KÜNG, Hans; SCHMIDT, Helmut. Uma ética mundial e responsabilidades globais - duas declarações. São Paulo: Loyola, 2001. p. 21.
} 
imagens de hostilidade, e quando devotam respeito às tradições, aos santuários, festas e ritos das pessoas de credos diferentes. ${ }^{239}$

Preocupa-se a Declaração, ainda, em relacionar quatro normas prescritivas decorrentes deste princípio, ${ }^{240}$ denominadas "quatro preceitos inamovíveis"241, as quais podem ser observadas "na maioria das grandes religiões deste mundo". ${ }^{242}$

O primeiro preceito inamovível consiste na ordem "Não matarás!"243, da qual decorre um "compromisso com a cultura da não violência e do temor diante de toda a vida" 244 , que pressupõe o seguinte:

a) respeito ao direito de toda e qualquer pessoa à vida, à integridade física, ao livre desenvolvimento da personalidade, observados os direitos dos demais; vedação à tortura, pois

pessoa alguma tem direito de torturar outra, seja física ou psiquicamente, nem de ferir, nem muito menos de matar a outrem. E nenhum povo, nenhum Estado, nenhuma raça ou religião têm o direito de discriminar uma minoria, de natureza ou credo diversos, nem proceder a qualquer purificação, exilá-la, nem muito menos aniquilá$1 \mathrm{a} ;{ }^{245}$

b) resolução dos conflitos de forma não violenta:

"Onde houver seres humanos, por certo também haverá conflitos. Esses conflitos, no entanto, deveriam ser resolvidos sem qualquer violência, no âmbito de uma ordem legal. Isso vale tanto para os indivíduos como para os Estados. Os detentores do poder político são especialmente chamados a se ater à ordem legal vigente, e a lutar por soluções pacíficas e não violentas quanto possível. Eles deveriam engajar-se em torno de uma ordem mundial pacífica, que de sua parte, necessita de proteção e defesa contra agentes de violência. Munir-se de armas é um descaminho, desarmar-se, uma exigência premente.

\footnotetext{
${ }^{239}$ KÜNG, Hans; SCHMIDT, Helmut. Uma ética mundial e responsabilidades globais - duas declarações. São Paulo: Loyola, 2001. p. 21.

${ }^{240}$ KÜNG, Hans; SCHMIDT, Helmut. Uma ética mundial e responsabilidades globais - duas declaraçães. São Paulo: Loyola, 2001. p. 23.

${ }^{241}$ KÜNG, Hans; SCHMIDT, Helmut. Uma ética mundial e responsabilidades globais - duas declarações. São Paulo: Loyola, 2001. p. 23.

${ }^{242}$ KÜNG, Hans; SCHMIDT, Helmut. Uma ética mundial e responsabilidades globais - duas declaraçães. São Paulo: Loyola, 2001. p. 23.

${ }^{243}$ KÜNG, Hans; SCHMIDT, Helmut. Uma ética mundial e responsabilidades globais - duas declarações. São Paulo: Loyola, 2001. p. 25.

${ }^{244}$ KÜNG, Hans; SCHMIDT, Helmut. Uma ética mundial e responsabilidades globais - duas declarações. São Paulo: Loyola, 2001. p. 25.

${ }^{245}$ KÜNG, Hans; SCHMIDT, Helmut. Uma ética mundial e responsabilidades globais - duas declarações. São Paulo: Loyola, 2001. p. 25.
} 
Que ninguém se engane: sem paz mundial, a humanidade não sobrevive, ${ }^{246}$

c) promoção de uma cultura da não-violência, que deveria ser ensinada aos jovens na família e nos colégios; ${ }^{247}$

d) preocupação também com a vida dos demais seres da natureza; ${ }^{248}$

e) postura de "tolerância, respeito e grande estima aos demais povos, raças e religiões mundiais" 249 .

O segundo preceito inamovível consiste na ordem "Não roubarás!", da qual decorre "compromisso com uma cultura da solidariedade e uma ordem econômica justa" ${ }^{250}$, que pressupõe o seguinte:

a) postura justa e honesta perante os outros, pois "pessoa alguma tem o direito de roubar outra - seja de que forma for - nem de violar sua propriedade ou os bens comunitários"; ${ }^{251}$

b) preocupação com uma justiça social, pois

Quando a pobreza extrema predomina, o desamparo e o desespero ganham espaço, e aí sempre se roubará, por força da sobrevivência. Quando se acumulam poder e riqueza indiscriminados, é inevitável que se despertem sentimentos de inveja e ressentimento, de ódio mortal e de rebelião. Isso conduz a um círculo vicioso de violência e reações violentas. Que ninguém se engane: não há paz mundial sem justiça mundial; ${ }^{252}$

c) conscientização dos jovens no sentido de que "a propriedade, por menor que seja, cria obrigação" ${ }^{253}$, pois "seu uso deve, ao mesmo tempo,

\footnotetext{
${ }^{246}$ KÜNG, Hans; SCHMIDT, Helmut. Uma ética mundial e responsabilidades globais - duas declarações. São Paulo: Loyola, 2001. p. 25.

${ }^{247}$ KÜNG, Hans; SCHMIDT, Helmut. Uma ética mundial e responsabilidades globais - duas declarações. São Paulo: Loyola, 2001. p. 27.

${ }^{248}$ KÜNG, Hans; SCHMIDT, Helmut. Uma ética mundial e responsabilidades globais - duas declaraçães. São Paulo: Loyola, 2001. p. 27.

${ }^{249}$ KÜNG, Hans; SCHMIDT, Helmut. Uma ética mundial e responsabilidades globais - duas declarações. São Paulo: Loyola, 2001. p. 27.

${ }^{250}$ KÜNG, Hans; SCHMIDT, Helmut. Uma ética mundial e responsabilidades globais - duas declarações. São Paulo: Loyola, 2001. p. 27.

${ }^{251}$ KÜNG, Hans; SCHMIDT, Helmut. Uma ética mundial e responsabilidades globais - duas declarações. São Paulo: Loyola, 2001. p. 27.

${ }^{252}$ KÜNG, Hans; SCHMIDT, Helmut. Uma ética mundial e responsabilidades globais - duas declarações. São Paulo: Loyola, 2001. p. 27.

${ }^{253}$ KÜNG, Hans; SCHMIDT, Helmut. Uma ética mundial e responsabilidades globais - duas declarações. São Paulo: Loyola, 2001. p. 27.
} 
servir ao bem comum" ${ }^{254}$, a fim de garantir "uma ordem econômica justa"; 255

d) adoção de medidas para "remodelar de forma mais justa as estruturas da economia mundial" ${ }^{256}$, uma vez que

A crise de endividamento e a pobreza do Segundo Mundo, ora em dissolução, e tanto mais do Terceiro Mundo, precisam ser conduzidas a uma solução sustentável por todas as partes. Certamente os conflitos de interesse serão inevitáveis também no futuro. Nos países desenvolvidos, de qualquer modo, deve-se distinguir entre consumo necessário e desenfreado, entre um uso social e associal da propriedade de mercado puramente capitalista, e outra, orientada tanto social como ecologicamente ${ }^{257}$

e) comprometimento com um comportamento verdadeiramente

humano, que significa o seguinte:

Ao invés de usurpar o poder econômico e político, em meio a uma luta irresponsável pelo domínio, deve-se utilizá-lo para o serviço ao ser humano. Precisamos desenvolver um espírito de compaixão com os que sofrem e ter uma preocupação especial com os pobres, deficientes, idosos, fugitivos e solitários.

Ao invés de um pensamento unicamente voltado ao poder e ao invés de uma política pelo poder desenfreada, é preciso prevalecer o respeito mútuo em meio à inevitável concorrência que surge na disputa pelo poder, um equilíbrio razoável dos interesses, e uma predisposição para o respeito e a conciliação.

Ao invés de um desejo insaciável por dinheiro, prestígio e consumo, é preciso reencontrar um novo senso de comedimento e humildade! Pois o ser humano entregue ao desejo perde sua alma, sua liberdade, seu desprendimento, sua paz interior e perde, com isso, o que o torna humano. ${ }^{258}$

O terceiro preceito inamovível consiste na ordem "Não mentirás!", da qual decorre um "compromisso com uma cultura da tolerância e uma vida de veracidade" ${ }^{259}$, que pressupõe o seguinte:

\footnotetext{
${ }^{254}$ KÜNG, Hans; SCHMIDT, Helmut. Uma ética mundial e responsabilidades globais - duas declarações. São Paulo: Loyola, 2001. p. 27.

${ }^{255}$ KÜNG, Hans; SCHMIDT, Helmut. Uma ética mundial e responsabilidades globais - duas declarações. São Paulo: Loyola, 2001. p. 27.

${ }^{256}$ KÜNG, Hans; SCHMIDT, Helmut. Uma ética mundial e responsabilidades globais - duas declaraçães. São Paulo: Loyola, 2001. p. 29.

${ }^{257}$ KÜNG, Hans; SCHMIDT, Helmut. Uma ética mundial e responsabilidades globais - duas declarações. São Paulo: Loyola, 2001. p. 29.

${ }^{258}$ KÜNG, Hans; SCHMIDT, Helmut. Uma ética mundial e responsabilidades globais - duas declaraçães. São Paulo: Loyola, 2001. p. 29.

${ }^{259}$ KÜNG, Hans; SCHMIDT, Helmut. Uma ética mundial e responsabilidades globais - duas declarações. São Paulo: Loyola, 2001. p. 29.
} 
a) postura de veracidade em relação aos outros, pois "pessoa alguma, nem nenhuma instituição, estado, igreja ou comunidade religiosa têm o direito de dizer inverdades às pessoas"; 260

b) comprometimento da propagação deste princípio na sociedade, no objetivo de alcançar, em especial, os seguintes destinatários:

b.1) os meios de comunicação de massa,

[...] aos quais felizmente se garante a liberdade de expressão para que a verdade seja dita, e aos quais se atribui, portanto, em todas as sociedades, um posto de guarda: eles não estão acima da moral, mas permanecem comprometidos, em sua objetividade e honestidade, com a dignidade humana, os direitos humanos e os valores fundamentais. Eles não têm direito algum de invadir a esfera particular das pessoas, distorcer a realidade, nem manipular a opinião pública; ${ }^{261}$

b.2) a arte, a literatura e a ciência, "às quais felizmente se garante com razão a liberdade artística e acadêmica: elas não estão desvinculadas de parâmetros éticos gerais, e devem se por a serviço da verdade"; 262

\section{b.3) os políticos e partidos políticos, pois}

[...] se eles mentem descaradamente ao povo e tornam-se internamente e externamente culpados pela manipulação da verdade, pela corrupção ou por uma política desrespeitosa, põem em jogo a própria credibilidade e merecem a perda de seus postos e de seus eleitores. Ao contrário, a opinião pública deve sempre apoiar os políticos que ousam sempre dizer a verdade ao povo; ${ }^{263}$

\section{b.4) os representantes de religiões, uma vez que}

[...] se eles incitam a preconceitos, ódio e hostilidade em relação a quem professa outras religiões, se apregoam o fanatismo, ou se até mesmo dão início ou legitimam guerras motivadas pela fé, então merecem condenação por parte dos seres humanos, e a perda de seus seguidores; $;^{264}$

\footnotetext{
${ }^{260}$ KÜNG, Hans; SCHMIDT, Helmut. Uma ética mundial e responsabilidades globais - duas declarações. São Paulo: Loyola, 2001. p. 31.

${ }^{261}$ KÜNG, Hans; SCHMIDT, Helmut. Uma ética mundial e responsabilidades globais - duas declarações. São Paulo: Loyola, 2001. p. 31.

${ }^{262}$ KÜNG, Hans; SCHMIDT, Helmut. Uma ética mundial e responsabilidades globais - duas declarações. São Paulo: Loyola, 2001. p. 31.

${ }^{263}$ KÜNG, Hans; SCHMIDT, Helmut. Uma ética mundial e responsabilidades globais - duas declarações. São Paulo: Loyola, 2001. p. 31.

${ }^{264}$ KÜNG, Hans; SCHMIDT, Helmut. Uma ética mundial e responsabilidades globais - duas declarações. São Paulo: Loyola, 2001. p. 33.
} 
c) conscientização dos jovens, na família e na escola, no sentido de "cultivar a veracidade em seu pensamento, em sua fala e em sua ação"; ${ }^{265}$

d) adoção das seguintes composturas:

[...] ao invés de confundir liberdade com arbitrariedade, e pluralismo com falta de critérios, fazer valer a verdade;

ao invés de viver desonestidade, dissimulação e acomodação oportunista, cultivar o espírito da veracidade, também nas relações quotidianas de pessoa para pessoa;

ao invés de divulgar meias verdades ideológicas ou partidárias, procurar sempre reiteradamente a verdade, em um espírito incorruptível de veracidade;

ao invés de render tributo ao oportunismo, e uma vez conhecida a verdade, servi-la com confiança e constância. ${ }^{266}$

O quarto preceito inamovível consiste na ordem "Respeitai e amai os outros!", da qual decorre um "compromisso com uma cultura de igualdade de direitos e do companheirismo entre homem e mulher", ${ }^{267}$ que pressupõe o seguinte:

a) postura de respeito em relação ao companheiro, pois "pessoa alguma tem o direito de degradar o outro a mero objeto de sua sexualidade, fazê-lo incidir ou mantê-lo em dependência sexual"; ${ }^{268}$

b) condenação da exploração sexual e da discriminação de gênero. Neste sentido,

Sempre que se apregoar a dominação de um sexo sobre o outro ou se tolerar a exploração sexual - tanto mais em nome de uma convicção religiosa -, e sempre que se fomentar a prostituição ou se abusar sexualmente de crianças, caberá opor-se a isso. Que ninguém se engane: não há verdadeira humanidade sem um convívio pautado pelo companheirismo!: ${ }^{269}$

c) conscientização dos jovens, na família e na escola, em relação ao fato de que

\footnotetext{
265 KÜNG, Hans; SCHMIDT, Helmut. Uma ética mundial e responsabilidades globais - duas declarações. São Paulo: Loyola, 2001. p. 33.

${ }^{266}$ KÜNG, Hans; SCHMIDT, Helmut. Uma ética mundial e responsabilidades globais - duas declarações. São Paulo: Loyola, 2001. p. 33.

267 KÜNG, Hans; SCHMIDT, Helmut. Uma ética mundial e responsabilidades globais - duas declarações. São Paulo: Loyola, 2001. p. 33.

${ }^{268}$ KÜNG, Hans; SCHMIDT, Helmut. Uma ética mundial e responsabilidades globais - duas declarações. São Paulo: Loyola, 2001. p. 33.

${ }^{269}$ KÜNG, Hans; SCHMIDT, Helmut. Uma ética mundial e responsabilidades globais - duas declarações. São Paulo: Loyola, 2001. p. 35.
} 
[...] a sexualidade não é uma força negativa-destruidora ou explorativa, mas uma força criadora e formadora. Sua função é afirmar a vida e criar comunidade; e ela só pode se desenvolver quando está sendo vivenciada a responsabilidade pela felicidade também do companheiro, ${ }^{270}$

d) promoção de uma sexualidade não limitada ao prazer sexual, mas como confirmação de uma relação amorosa vivida com companheirismo. Sobre o tema, complementa-se que "Algumas tradições religiosas também conhecem o ideal da renúncia ao desenvolvimento da sexualidade. A renúncia voluntária também pode ser expressão de identidade e de plenificação de sentido"; ${ }^{271}$

e) afirmação dos deveres da família, que devem:

[...] garantir a homens, mulheres e crianças, proteção e apoio mútuo, bem como assegurar seus direitos. Em todos os países e culturas é preciso empenhar-se por condições econômicas e sociais que possibilitem uma existência humanamente digna do casamento, da família, e em especial das pessoas idosas. As crianças têm direito à educação. Nem os pais devem aproveitar-se dos filhos, nem os filhos, dos pais; seu relacionamento deve ser sustentado, sim, pelo respeito, reconhecimento e cuidado mútuo; ${ }^{272}$

f) adoção das seguintes composturas, uma vez que "no plano das nações e religiões só se pode praticar o que já se vive no plano das relações pessoais e familiares": ${ }^{273}$

[...] ao invés de dominação ou humilhação, que são expressões de violência e frequentemente geram reações violentas, cultivar respeito, compreensão, companheirismo.

ao invés de toda a forma de desejo sexual possessivo ou abuso sexual, cultivar respeito mútuo, tolerância, conciliação, amor. ${ }^{274}$

\footnotetext{
${ }^{270}$ KÜNG, Hans; SCHMIDT, Helmut. Uma ética mundial e responsabilidades globais - duas declarações. São Paulo: Loyola, 2001. p. 35.

${ }^{271}$ KÜNG, Hans; SCHMIDT, Helmut. Uma ética mundial e responsabilidades globais - duas declarações. São Paulo: Loyola, 2001. p. 35.

${ }^{272}$ KÜNG, Hans; SCHMIDT, Helmut. Uma ética mundial e responsabilidades globais - duas declarações. São Paulo: Loyola, 2001. p. 35.

${ }^{273}$ KÜNG, Hans; SCHMIDT, Helmut. Uma ética mundial e responsabilidades globais - duas declarações. São Paulo: Loyola, 2001. p. 35.

${ }^{274}$ KÜNG, Hans; SCHMIDT, Helmut. Uma ética mundial e responsabilidades globais - duas declarações. São Paulo: Loyola, 2001. p. 35.
} 
Para que seja colocado em prática tudo o que consta acima exposto, na Parte IV da Declaração enfatiza-se a necessidade de uma mudança de consciência:

Todas as experiências históricas demonstram: não se pode mudar nosso planeta sem que se chegue a mudanças de consciência no indivíduo e na opinião pública. Isso já se evidenciou em questões como guerra e paz, economia e ecologia, que passaram por mudanças fundamentais nas últimas décadas. Tais mudanças também devem ser alcançadas em vista da ética! Todo indivíduo possui não apenas uma dignidade intocável e direitos inalienáveis; ele tem também uma responsabilidade irrefutável pelo que faz ou deixa de fazer. Todas as nossas decisões e atos, assim como nossas conquistas e fracassos, têm consequências. Manter viva essa responsabilidade, aprofundá-la e transmiti-la para gerações futuras - eis uma importante incumbência das religiões. ${ }^{275}$

Neste sentido, afirma-se que, para cumprir a referida incumbência, devem as religiões considerar o seguinte:

1. É difícil obter um consenso universal para muitas questões éticas específicas e polêmicas (desde a bioética e a ética sexual, a ética da ciência e dos meios de comunicação, até a ética econômica e do Estado). Contudo, no espírito dos princípios comuns aqui desenvolvidos, deveriam ser encontradas soluções objetivas também para muitas das questões que permanecem polêmicas até o momento.

2. Em muitos campos da vida já se despertou uma nova consciência para a responsabilidade ética. Consideramos louvável, portanto, que o maior número possível de classes profissionais, como os médicos, cientistas, comerciantes, jornalistas e políticos, elaborem códigos de ética capazes de fornecer diretrizes concretas para questões provocativas de seu respectivo meio profissional.

3. Instamos sobretudo com as comunidades de fé em particular para que formulem sua ética específica: o que cada uma das tradições de fé tem a dizer sobre o sentido da vida e da morte, sobre suportar o sofrimento e perdoar a culpa, sobre a entrega abnegada e a necessidade de renúncia, sobre compaixão e alegria. Tudo isso contribuirá para aprofundar, especificar e concretizar a ética mundial que já se reconhece nesse momento. ${ }^{276}$

\section{Ao final da Declaração, faz-se um convite a todos os indivíduos:}

Por fim, apelamos a todos os habitantes do nosso planeta: não se pode mudar nossa Terra para melhor sem que se mude a consciência do indivíduo. Pronunciamo-nos em favor de uma mudança individual e coletiva da consciência, em favor de um despertar de nossas forças

\footnotetext{
275 KÜNG, Hans; SCHMIDT, Helmut. Uma ética mundial e responsabilidades globais - duas declarações. São Paulo: Loyola, 2001. p. 35.

${ }^{276}$ KÜNG, Hans; SCHMIDT, Helmut. Uma ética mundial e responsabilidades globais - duas declarações. São Paulo: Loyola, 2001. p. 37.
} 
espirituais por meio da reflexão, meditação, oração e pensamento positivo, e em favor de uma conversão de corações. Juntos podemos mover montanhas. Sem riscos e disposições ao sacrifício não haverá mudança de em nossa situação. Por isso comprometemo-nos com uma ética mundial: com uma maior compreensão mútua, e com formas de vida compatíveis com as dinâmicas sociais, promotoras da paz e benéficas à natureza. Convidamos todos os seres humanos, religiosos ou não, a fazerem o mesmo. ${ }^{277}$

Como já exposto, a referida Declaração foi assinada por representantes $^{278}$ de diversas vertentes de religiões orientais e ocidentais, tais como: religião Bahai; Brahma Kumaris; Budismo; Budismo Mahayana; Budismo Theravada; Budismo Vajrayana; Cristianismo; Cristianismo Anglicano; Cristianismo Ortodoxo; Cristianismo Protestante; Cristianismo Católico-Romano; Religiões Nativas; Religião Nativa Akuapi; Religião Nativa Yoruba; Religião Americana Nativa; Hinduísmo; Hinduísmo Vedanta; Jainismo; Digambar; Shwetambar; Judaísmo; Judaísmo Conservador; Judaísmo Reformado; Judaísmo Ortodoxo; Islamismo; Islamismo Sunita; Islamismo Xiita; Neopaganismo; Sikhs; Sikhs Taoísta; Teosofista; e Zoroastristas.

Cumpre esclarecer, porém, que alguns dos signatários da Declaração fizeram objeções a trechos pontuais do documento - uma vez que o conteúdo da declaração de ética mundial não mais podia ser alterado na reunião do Segundo Parlamento das Religiões Mundiais:

a) na seção sobre a cultura da não violência, "algumas pessoas particularmente em vista da desesperadora situação dos muçulmanos na Bósnia - acharam que o direito à autodefesa (também afirmado na Carta das Nações Unidas) não foi ressaltado com clareza suficiente". ${ }^{279}$ A respeito desta objeção, Küng esclarece que a

Declaração deliberadamente assumiu um meio-termo que pudesse garantir o consenso: entre a Realpolitik da força na resolução dos

\footnotetext{
${ }^{277}$ KÜNG, Hans; SCHMIDT, Helmut. Uma ética mundial e responsabilidades globais - duas declarações. São Paulo: Loyola, 2001. p. 37.

${ }^{278}$ Para conferir os nomes dos representantes das religiões que subscreveram a Declaração, ver nota de rodapé 44 deste trabalho.

${ }^{279}$ KÜNG, Hans; SCHMIDT, Helmut. Uma ética mundial e responsabilidades globais - duas declarações. São Paulo: Loyola, 2001. p. 72.
} 
conflitos e um pacifismo incondicional irreal. [...] Conclui-se disso que o direito à autodefesa é afirmado tanto para o indivíduo como para o coletivo - mas no contexto de uma cultura da não violência ele se aplica apenas in extremis, a saber, quando não faz sentido a resistência pacífica. Diante da brutalidade, da barbárie e do genocídio, [...] a autodefesa é permissível. [...] De outro lado, não se deve fornecer uma fórmula simples de legitimação para nenhum tipo de intervenção militar: nenhuma "guerra justa" a serviço de interesses descaradamente econômicos, políticos e militares será justificada dessa maneira ${ }^{280}$;

b) na seção que trata da cultura de direitos iguais e parceria entre homens e mulheres, afirmou-se que "o texto da declaração falava muito pouco sobre a família". ${ }^{281}$ Sobre essa ressalva, Küng explica que o texto contém "declarações sobre casamento, família, educação, pais e filhos" 282 , e o problema foi decorrente da tradução inglesa, "que em alguns pontos verteu a expressão alemã 'na família' para 'no lar'”, ${ }^{283}$

A respeito do que consta afirmado nesta seção, porém, Küng pondera que, em que pese não terem sido feitas objeções a respeito da igualdade entre homens e mulheres:

É preciso se admitir que o que se diz nessa seção sobre direitos iguais para homens e mulheres apresenta, sem sombra de dúvida, um desafio não apenas para alguns muçulmanos e hindus, mas também para cristãos americanos e europeus mais conservadores. Por certo, a Declaração deliberadamente não diz nada sobre o papel da mulher no culto; a ordenação das mulheres é uma questão altamente controversa na maioria das igrejas cristãs e não faz parte de nenhum documento consensual. Mas, mesmo sem tal declaração, há nessa seção declarações individuais sobre as mulheres que devem incitar alguns muçulmanos e hindus a refletir sobre suas próprias posições. ${ }^{284}$

\footnotetext{
${ }^{280}$ KÜNG, Hans; SCHMIDT, Helmut. Uma ética mundial e responsabilidades globais - duas declarações. São Paulo: Loyola, 2001. p. 72.

${ }^{281}$ KÜNG, Hans; SCHMIDT, Helmut. Uma ética mundial e responsabilidades globais - duas declarações. São Paulo: Loyola, 2001. p. 72.

${ }^{282}$ KÜNG, Hans; SCHMIDT, Helmut. Uma ética mundial e responsabilidades globais - duas declarações. São Paulo: Loyola, 2001. p. 72.

${ }^{283}$ KÜNG, Hans; SCHMIDT, Helmut. Uma ética mundial e responsabilidades globais - duas declarações. São Paulo: Loyola, 2001. p. 72.

${ }^{284}$ KÜNG, Hans; SCHMIDT, Helmut. Uma ética mundial e responsabilidades globais - duas

declarações. São Paulo: Loyola, 2001. p. 72.
} 
c) por fim, a última crítica endereçada à Declaração foi no sentido de que esta era "demasiado ocidental": 285

A objeção não entrava em detalhes, mas o teor era provavelmente de que nessa Declaração as coisas não foram reduzidas a palavras chave como "consciência cósmica", "harmonia espiritual mundial", "vínculo com o universo", "unidade de alma e cosmos". No entanto, deve-se reconhecer que, sem dúvida, uma declaração diferirá conforme tenha sido projetada por um monge tai, um swami hindu, um mestre zen, um rabi judeu, um aiatolá muçulmano ou um teólogo cristão. Cada um tem seu próprio estilo, sua própria abordagem, que carregam um matiz religioso e cultural básico particular. Sempre tive consciência da minha própria relatividade cultural e política; contudo, o processo de consulta internacional e inter-religiosa no começo tinha o objetivo de tornar essa realidade tão tolerável quanto possível. ${ }^{286}$

Do que se extrai das objeções formuladas, é possível afirmar que nenhuma delas, porém, prejudicava a proposta da Declaração. Assim, conforme já esclarecido, Küng entende que a Declaração pode ser vista como exemplo de iniciativa em busca do ethos mundial, uma vez que, por meio da subscrição deste documento, comprovou-se a viabilidade de extrair, de um diálogo inter-religioso, princípios éticos universais. Acrescenta o autor que a Declaração,

[...] assinada por pessoas tão importantes - o Dalai Lama, o Cardeal de Chicago, o representante do Vaticano, o do Concílio Mundial das Igrejas, o secretário geral da Conferência Mundial das Religiões para a Paz, o diretor geral da Comunidade Baha'i Internacional, o líder espiritual dos siques de Amritsar, um presidente da Aliança Mundial Luterana, o patriarca do budismo cambojano, um líder rabino e um sheik árabe - representa um sinal inequívoco de esperança para o futuro das religiões e paz do mundo, que, sem sombra de dúvidas, mal poderia ter sido conjecturado pouco tempo atrás. ${ }^{287}$

\subsection{A Declaração Universal das Responsabilidades Humanas}

Hans Küng foi convidado a elaborar a Declaração Universal das Responsabilidades Humanas, em novembro de 1995, por Helmut Schmidt, ex-chanceler (premiê) da República Federal da Alemanha (1974-82) e, à

\footnotetext{
${ }^{285}$ KÜNG, Hans; SCHMIDT, Helmut. Uma ética mundial e responsabilidades globais - duas declarações. São Paulo: Loyola, 2001. p. 73.

${ }^{286}$ KÜNG, Hans; SCHMIDT, Helmut. Uma ética mundial e responsabilidades globais - duas declarações. São Paulo: Loyola, 2001. p. 73.

${ }^{287}$ KÜNG, Hans; SCHMIDT, Helmut. Uma ética mundial e responsabilidades globais - duas declarações. São Paulo: Loyola, 2001. p. 77.
} 
época, presidente honorário do InterAction Council, associação composta por ex-chefes de Estado e de governos. ${ }^{288} \mathrm{O}$ convite era resultado da percepção de que, "quase meio século depois da Declaração de Direitos Humanos, o necessário imperativo moral dessa declaração para a humanidade e seus duzentos Estados soberanos corre perigo" ${ }^{289}$, uma vez que: a) "o termo "direitos humanos" está sendo usado por alguns políticos ocidentais [...] como um brado de guerra e um instrumento agressivo para exercer pressão sobre política externa" ${ }^{290}$; b) os direitos humanos passaram a ser vistos "por alguns muçulmanos, hindus e confucianos como um conceito tipicamente ocidental e, às vezes, denunciados como um instrumento para ampliar a dominação ocidental" ${ }^{291}$; c) a Declaração de Direitos Humanos não afirma expressamente as responsabilidades humanas por parte do indivíduo em relação à família, à comunidade, à sociedade e ao Estado. $^{292}$

Desta forma, tal Declaração tinha por objetivo relacionar as responsabilidades de todo e qualquer indivíduo no processo de busca por melhor ordem mundial ${ }^{293}$ - responsabilidades estas decorrentes de "padrões éticos reconhecidos em todo o mundo" ${ }^{294}$, necessários "para a convivência intercontinental - não apenas para a conduta individual, mas também para autoridades políticas, comunidades religiosas, Igrejas e nações" ${ }^{295}-$, e teria "o caráter de um apelo ético, não o caráter obrigatório de lei

\footnotetext{
${ }^{288}$ KÜNG, Hans; SCHMIDT, Helmut. Uma ética mundial e responsabilidades globais - duas declarações. São Paulo: Loyola, 2001. p. 82.

${ }^{289}$ KÜNG, Hans; SCHMIDT, Helmut. Uma ética mundial e responsabilidades globais - duas declarações. São Paulo: Loyola, 2001. p. 82.

${ }^{290}$ KÜNG, Hans; SCHMIDT, Helmut. Uma ética mundial e responsabilidades globais - duas declarações. São Paulo: Loyola, 2001. p. 82.

${ }^{291}$ KÜNG, Hans; SCHMIDT, Helmut. Uma ética mundial e responsabilidades globais - duas declarações. São Paulo: Loyola, 2001. p. 82.

${ }^{292}$ KÜNG, Hans; SCHMIDT, Helmut. Uma ética mundial e responsabilidades globais - duas declarações. São Paulo: Loyola, 2001. p. 82.

${ }^{293}$ KÜNG, Hans; SCHMIDT, Helmut. Uma ética mundial e responsabilidades globais - duas declarações. São Paulo: Loyola, 2001. p. 82.

${ }^{294}$ KÜNG, Hans; SCHMIDT, Helmut. Uma ética mundial e responsabilidades globais - duas declarações. São Paulo: Loyola, 2001. p. 85.

${ }^{295}$ KÜNG, Hans; SCHMIDT, Helmut. Uma ética mundial e responsabilidades globais - duas declarações. São Paulo: Loyola, 2001. p. 85.
} 
internacional". ${ }^{296}$ Sobre o caráter não vinculante da Declaração de Responsabilidades Humanas, esclarece Helmut Schmidt:

Os que consideram os autores e signatários do projeto de uma Declaração Universal de Responsabilidades Humanas meros idealistas sem os pés no chão não tem uma visão histórica adequada da verdadeira influência histórica da Declaração dos Direitos Humanos, que no início não era legalmente obrigatória, nem uma noção adequada dos perigos da humanidade no futuro; poderiam ser simplesmente defensores conservadores do que é erroneamente chamado Realpolitik, que em princípio não contém nenhuma moralidade. ${ }^{297}$

Em resposta ao convite de Helmut Schmidt, Küng sugeriu a realização de dois encontros com representantes do InterAction Council, os quais lhe dariam subsídio para um primeiro esboço da Declaração de Responsabilidades Humanas.

De 22 a 24 de março de 1996, realizou-se em Viena um encontro entre membros da InterAction Council, o qual também contou com a participação de "estudiosos e dignitários espirituais do mundo inteiro"298, representantes do judaísmo, do cristianismo, do islamismo, do budismo e do confucionismo. ${ }^{299}$ A partir desse encontro, elaborou-se um relatório com o primeiro esboço do que deveria constar na Declaração de Responsabilidades Humanas.

Do dia 19 ao dia 22 de maio de 1996, realizou-se em Vancouver o encontro anual do InterAction Council, no qual transformou-se o relatório em

[...] parágrafos sob os temas da globalização, da Declaração das Religiões do Mundo de Chicago, do tornar os padrões éticos mundiais

\footnotetext{
${ }^{296}$ KÜNG, Hans; SCHMIDT, Helmut. Uma ética mundial e responsabilidades globais - duas declarações. São Paulo: Loyola, 2001. p. 85.

${ }^{297}$ KÜNG, Hans; SCHMIDT, Helmut. Uma ética mundial e responsabilidades globais - duas declarações. São Paulo: Loyola, 2001. p. 85.

${ }^{298}$ KÜNG, Hans; SCHMIDT, Helmut. Uma ética mundial e responsabilidades globais - duas declarações. São Paulo: Loyola, 2001. p. 85.

${ }^{299}$ FRÜHBAUER, Johannes. Da Declaração das Religiões à Declaração dos Estadistas - Estágios na composição da Declaração sobre Responsabilidades Humanas. In: KÜNG, Hans; SCHMIDT, Helmut. Uma ética mundial e responsabilidades globais - duas declarações. São Paulo: Loyola, 2001. p. 89 .
} 
um tópico fundamental de interesse público e da crucial importância da educação no contexto de valores éticos globais. ${ }^{300}$

Confirmou-se, nesse encontro, a convicção básica de que "a ética deve preceder a política e até mesmo o direito, porque a ação política se envolve com valores e escolhas". 301

De 20 a 22 de abril de 1997, ocorreu um segundo encontro em Viena para tratar da Declaração de Responsabilidades Humanas, e após intensas discussões, elaborou-se uma versão melhorada do anteprojeto. ${ }^{302}$

Na sequência, "o texto do projeto que fora trabalhado foi enviado aos peritos, que agora tinham uma oportunidade para comentar sua forma e seu conteúdo" ${ }^{303}$, e a outros importantes conselheiros, "alguns dos quais participaram da primeira sessão do Projeto de Ética Mundial da UNESCO, em Paris, em 1997". 304

Com base nas respostas recebidas, Küng "adaptou tanto quanto possível as propostas de correções e trabalhou no texto. Por fim, tinha-se um documento que poderia ser apresentado ao InterAction Council como um todo" ${ }^{305}$, o que ocorreu na "reunião plena do InterAction Council, em Noordwijk, Países Baixos, de $1^{\text {o a }} 4$ de junho de 1997". 306

\footnotetext{
${ }^{300}$ FRÜHBAUER, Johannes. Da Declaração das Religiões à Declaração dos Estadistas - Estágios na composição da Declaração sobre Responsabilidades Humanas. In: KÜNG, Hans; SCHMIDT, Helmut. Uma ética mundial e responsabilidades globais - duas declarações. São Paulo: Loyola, 2001. p. 99

${ }^{301}$ Communique of the InterAction Council 14th Session. 19-22 May 1996. Vancouver, BC, Canadá apud FRÜHBAUER, Johannes. Da Declaração das Religiões à Declaração dos Estadistas Estágios na composição da Declaração sobre Responsabilidades Humanas. In: KÜNG, Hans; SCHMIDT, Helmut. Uma ética mundial e responsabilidades globais - duas declarações. São Paulo: Loyola, 2001. p. 99.

${ }^{302}$ FRÜHBAUER, Johannes. Da Declaração das Religiões à Declaração dos Estadistas - Estágios na composição da Declaração sobre Responsabilidades Humanas. In: KÜNG, Hans; SCHMIDT, Helmut. Uma ética mundial e responsabilidades globais - duas declarações. São Paulo: Loyola, 2001.p. 89.

${ }^{303}$ FRÜHBAUER, Johannes. Da Declaração das Religiões à Declaração dos Estadistas - Estágios na composição da Declaração sobre Responsabilidades Humanas. In: KÜNG, Hans; SCHMIDT, Helmut. Uma ética mundial e responsabilidades globais - duas declarações. São Paulo: Loyola, 2001. p. 104.

${ }^{304}$ FRÜHBAUER, Johannes. Da Declaração das Religiões à Declaração dos Estadistas - Estágios na composição da Declaração sobre Responsabilidades Humanas. In: KÜNG, Hans; SCHMIDT, Helmut. Uma ética mundial e responsabilidades globais - duas declarações. São Paulo: Loyola, 2001.p. 104.

${ }^{305}$ FRÜHBAUER, Johannes. Da Declaração das Religiões à Declaração dos Estadistas - Estágios na composição da Declaração sobre Responsabilidades Humanas. In: KÜNG, Hans; SCHMIDT,
} 
No encontro de Noordwijk, após inúmeros debates sobre o texto final da Declaração, decidiu-se que todos os presentes "deveriam estudar o texto presente e mandar sugestões de aperfeiçoamento ou sugestões alternativas dentro de dois meses, até o final de julho". ${ }^{307}$

Assim, em agosto de 1977, o documento definitivo foi apresentado a todos os membros do InterAction Council, e publicado pelo novo presidente, Malcom Fraser, com data de $1^{\circ}$ de setembro de 1997. Na mesma data, o documento foi enviado ao secretário geral da Organização das Nações Unidas, Kofi Annan, "e aos governos nacionais por todo o mundo". ${ }^{308}$ Tal Declaração, publicada originalmente em inglês, japonês e alemão, atualmente encontra-se disponível em mais de dezesseis línguas. ${ }^{309}$

Isto posto, passemos a analisar o conteúdo da Declaração Universal das Responsabilidades Humanas. ${ }^{310}$

A Declaração de Responsabilidades Humanas é composta por dezenove artigos, distribuídos da seguinte forma: a) Comentário Introdutório; b) Preâmbulo; c) Princípios Fundamentais para a Humanidade; d) Não violência e respeito pela vida; e) Justiça e Solidariedade; f) Sinceridade e Tolerância; g) Respeito Mútuo e Parceria; h) Conclusão.

Helmut. Uma ética mundial e responsabilidades globais - duas declarações. São Paulo: Loyola, 2001. p. 104.

${ }^{306}$ FRÜHBAUER, Johannes. Da Declaração das Religiões à Declaração dos Estadistas - Estágios na composição da Declaração sobre Responsabilidades Humanas. In: KÜNG, Hans; SCHMIDT, Helmut. Uma ética mundial e responsabilidades globais - duas declarações. São Paulo: Loyola, 2001. p. 104.

${ }^{307}$ FRÜHBAUER, Johannes. Da Declaração das Religiões à Declaração dos Estadistas - Estágios na composição da Declaração sobre Responsabilidades Humanas. In: KÜNG, Hans; SCHMIDT, Helmut. Uma ética mundial e responsabilidades globais - duas declarações. São Paulo: Loyola, 2001. p. 105.

${ }^{308}$ FRÜHBAUER, Johannes. Da Declaração das Religiões à Declaração dos Estadistas - Estágios na composição da Declaração sobre Responsabilidades Humanas. In: KÜNG, Hans; SCHMIDT, Helmut. Uma ética mundial e responsabilidades globais - duas declarações. São Paulo: Loyola, 2001. p. 105.

${ }^{309}$ FRÜHBAUER, Johannes. Da Declaração das Religiões à Declaração dos Estadistas - Estágios na composição da Declaração sobre Responsabilidades Humanas. In: KÜNG, Hans; SCHMIDT, Helmut. Uma ética mundial e responsabilidades globais - duas declarações. São Paulo: Loyola, 2001. p. 105

${ }^{310}$ Para conferir todos os signatários desta Declaração, ver nota de rodapé 53 deste trabalho. 
No Comentário Introdutório, apresenta-se a motivação da Declaração

\section{de Responsabilidades Humanas:}

A globalização da economia mundial é desafiada por problemas mundiais, que exigem soluções globais baseadas em idéias, valores e normas respeitados por todas as culturas e sociedades. $\mathrm{O}$ reconhecimento de direitos iguais e inalienáveis requer um fundamento de liberdade, justiça e paz - mas para isso também é necessário que os direitos e responsabilidades humanas recebam importância igual para estabelecer uma base ética [...]. Uma melhor ordem social, tanto nacional quanto internacional, não pode ser alcançada apenas com leis, preceitos e convenções; ela precisa também de uma ética mundial. ${ }^{311}$

No mesmo sentido, complementa o Preâmbulo da Declaração, por meio de "Considerandos":

Considerando que o reconhecimento da dignidade inerente e dos direitos iguais e inalienáveis de todos os membro da família humana é o fundamento da liberdade, justiça e paz no mundo e implica obrigações ou responsabilidades,

considerando que a insistência exclusiva nos direitos pode resultar em conflito, divisão e disputa interminável, e que a negligência das responsabilidades humanas pode levar à ilegalidade e ao caos,

considerando que o domínio da lei e a promoção dos direitos humanos dependem da prontidão de homens e mulheres em agir com justiça,

considerando que os problemas globais exigem soluções globais que só podem ser alcançadas por meio de idéias, valores e normas respeitados por todas as culturas e sociedades,

considerando que todos os indivíduos, no gozo de seus melhores conhecimentos e capacidades, têm a responsabilidade de promover uma melhor ordem social, tanto em seu país, quanto internacionalmente, objetivo este que não pode ser alcançado somente mediante leis, prescrições e convenções,

considerando que as aspirações humanas por progresso e aperfeiçoamento só podem ser concretizadas mediante valores e padrões comumente acordados, que se apliquem a todas as pessoas e instituições em todas as épocas,

Agora, portanto, a Assembleia Geral proclama esta Declaração Universal dos Deveres do Homem com um critério comum para todas as pessoas e todas as nações, a fim de que todo o indivíduo e todo o órgão da sociedade, tendo sempre em mente esta Declaração, contribua para o progresso das comunidades e o esclarecimento de todos os seus membros. Nós, os povos do mundo, renovamos e reforçamos assim os compromissos já proclamados na Declaração Universal dos Direitos Humanos, a saber, a plena aceitação da dignidade de todas as pessoas, sua liberdade e sua igualdade inalienáveis, e sua solidariedade mútua. A conscientização e a

${ }^{311}$ Comentário Introdutório da Declaração de Responsabilidades Humanas, publicada em $1^{\circ}$ de setembro de 1997 pelo InterAction Council. 
aceitação dessas responsabilidades devem ser ensinadas e promovidas em todo o mundo. ${ }^{312}$

A primeira seção da Declaração, denominada "Princípios fundamentais para a humanidade", é formada por quatro artigos, dos quais se extraem os seguintes deveres: a) o dever de tratar todas as pessoas de maneira humana; b) o dever de lutar para que todos tenham liberdade e dignidade; c) o dever de promover o bem e de evitar o mal em todas as ocasiões; d) o dever de não fazer aos outros o que não deseja que outros lhe façam:

Artigo $1^{\mathrm{o}}$ : Toda pessoa, independentemente do gênero, origem étnica, status social, opinião política, língua, idade, nacionalidade ou religião, tem o dever de tratar todas as pessoas de maneira humana.

Artigo $2^{\circ}$ : Ninguém deve apoiar nenhuma forma de comportamento desumano, mas todos têm a responsabilidade de lutar pela liberdade e auto-estima de todos os demais.

Artigo $3^{\circ}$ : Nenhuma pessoa, nenhum grupo ou organização, nenhum Estado, nenhum exército ou polícia está acima do bem e do mal; todos estão sujeitos a padrões éticos. Todos têm a responsabilidade de promover o bem e de evitar o mal em todas as ocasiões.

Artigo $4^{\circ}$ : Todas as pessoas, dotadas de razão e consciência, devem aceitar a responsabilidade para com todos, para com as famílias e comunidades, para com as raças, nações e religiões, com espírito de solidariedade: Não faça aos outros o que não queres que façam a ti. ${ }^{313}$

A segunda seção da Declaração, denominada "Não-Violência e Respeito pela Vida", é formada por três artigos, dos quais se extraem os seguintes deveres: a) o dever de respeitar a vida, que se traduz no combate a atos que agridam, torturem ou matem outras pessoas; b) o dever de buscar resolver os conflitos de forma pacífica; c) o dever de conscientizar-se ecologicamente e de proteger a natureza:

Artigo 5 $5^{\circ}$ : Todos têm o dever de respeitar a vida. Ninguém tem o direito de ferir, torturar ou matar outra pessoa humana. Isto não exclui o direito à autodefesa justificada de indivíduos ou comunidades.

Artigo $6^{\circ}$ : Os litígios entre Estados, grupos ou indivíduos devem ser resolvidos sem violência. Nenhum governo deve tolerar ou participar

\footnotetext{
${ }^{312}$ Preâmbulo da Declaração de Responsabilidades Humanas, publicada em $1^{\circ}$ de setembro de 1997 pelo InterAction Council.

${ }^{313}$ Seção " Princípios fundamentais para a humanidade" da Declaração de Responsabilidades Humanas, publicada em $1^{\circ}$ de setembro de 1997 pelo InterAction Council.
} 
de atos de genocídio ou terrorismo, nem deve usar homens, crianças ou quaisquer outros civis como instrumentos de guerra. Todo o cidadão e toda a autoridade pública têm o dever de agir de forma pacífica, não-violenta.

Artigo $7^{\circ}$ : Toda pessoa é infinitamente preciosa e deve ser protegida incondicionalmente. Os animais e o meio ambiente natural também exigem proteção. Todas as pessoas têm o dever de proteger o ar, a água e o solo da terra para o bem dos habitantes atuais e das gerações futuras. ${ }^{314}$

A terceira seção da Declaração, denominada "Justiça e Solidariedade", é formada por três artigos, dos quais se extraem os seguintes deveres: a) o dever de portar-se com integridade, honestidade e justiça; b) o dever de esforçar-se para erradicar problemas sociais como a pobreza, a desnutrição, a ignorância, a desigualdade; c) o dever de buscar uma ordem econômica e social justa:

Artigo $8^{\circ}$ : Todos têm a responsabilidade de comportar-se com integridade, honestidade e equidade. Nenhum indivíduo ou grupo deve roubar ou arbitrariamente privar qualquer outro indivíduo ou grupo dos seus bens.

Artigo $9^{\circ}$ : Todas as pessoas, dados os instrumentos necessários, têm a responsabilidade de fazer sérios esforços para vencer a pobreza, a desnutrição, a ignorância e a desigualdade. Devem promover o desenvolvimento sustentável em todo o mundo, com o fim de assegurar dignidade, liberdade, segurança e justiça para todos.

Artigo 10: Todas as pessoas têm a responsabilidade de desenvolver os seus talentos mediante esforços diligentes; devem ter acesso igual à educação e ao trabalho significativo. Todos devem prestar auxílio aos necessitados, aos desprestigiados, aos deficientes e às vitimas de discriminação.

Artigo 11: Todos os bens e toda a riqueza devem ser usados de forma responsável, de acordo com a justiça e para o progresso da raça humana. O poder econômico e político não deve ser tratado como instrumento de dominação, mas estar ao serviço da justiça econômica e da ordem social. ${ }^{315}$

A quarta seção da Declaração, denominada "Sinceridade e Tolerância", é formada por quatro artigos, dos quais se extraem os seguintes deveres: a) o dever de falar e agir de forma honesta - ainda que ninguém esteja obrigado a ser sincero o tempo todo; b) o dever de respeitar a

\footnotetext{
${ }^{314}$ Seção "Não-Violência e Respeito pela Vida" da Declaração de Responsabilidades Humanas, publicada em $1^{\circ}$ de setembro de 1997 pelo InterAction Council.

315 Seção "Sinceridade e Tolerância" da Declaração de Responsabilidades Humanas, publicada em $1^{\circ}$ de setembro de 1997 pelo InterAction Council.
} 
privacidade e o sigilo pessoal e profissional; c) o dever de seguir padrões éticos gerais no exercício da profissão, seja esta qual for; d) o dever dos meios de comunicação de prestar informações verdadeiras, de forma responsável; e) o dever, em especial dos líderes religiosos, de combater manifestações de preconceito e atos de discriminação contra as pessoas de crenças diferentes, incitações ao ódio, ao fanatismo e às guerras religiosas; f) o dever de promover a tolerância e o respeito mútuo entre todos os indivíduos:

Artigo 12: Todos têm o dever de falar e agir com sinceridade. Ninguém, por mais superior ou poderoso que seja, deve mentir. O direito à privacidade e ao sigilo pessoal deve ser respeitado. Ninguém é obrigado a dizer toda a verdade, a todas as pessoas o tempo todo.

Artigo 13: Nenhum político, funcionário público, dirigente da economia, cientista, escritor ou artista está isento dos padrões éticos gerais; tampouco o estão os médicos, advogados e outros profissionais que têm deveres especiais para com os clientes. Códigos profissionais e outros códigos de ética devem refletir a prioridade de padrões gerais como a sinceridade e a equidade.

Artigo 14: A liberdade de mídia de informar o público e criticar as instituições da sociedade e as ações governamentais, que é essencial para uma sociedade justa, deve ser usada com responsabilidade e discrição. A liberdade da mídia carrega uma responsabilidade pelo jornalismo exato e veraz. Reportagens sensacionalistas que degradam a pessoa ou a dignidade humana devem ser evitadas em todas as ocasiões.

Artigo 15: Embora a liberdade religiosa deva ser garantida, os representantes das religiões têm a responsabilidade especial de evitar expressões de preconceito e atos de discriminação contra as pessoas de crenças diferentes. Não devem incitar ou legitimar o ódio, o fanatismo e as guerras religiosas, mas promover a tolerância e o respeito mútuo entre todas as pessoas. ${ }^{316}$

A quinta seção da Declaração, denominada "Respeito Mútuo e Parceria", é formada por três artigos, dos quais se extraem os seguintes deveres: a) o dever de agir com respeito, compreensão, solidariedade, lealdade e amor nos relacionamentos amorosos e nos relacionamentos familiares; b) o dever de preocupar-se com o planejamento familiar:

Artigo 16: Todos os homens e mulheres têm a responsabilidade de mostrar respeito uns pelos outros e compreensão em sua parceria.

\footnotetext{
316 Seção "Sinceridade e Tolerância" da Declaração de Responsabilidades Humanas, publicada em $1^{\circ}$ de setembro de 1997 pelo InterAction Council.
} 
Ninguém deve sujeitar outra pessoa à exploração ou dependência sexual. Ao contrário, os parceiros sexuais devem aceitar a responsabilidade de cuidar do bem-estar mútuo.

Artigo 17: Em todas suas variedades culturais e religiosas, o casamento requer amor, lealdade e perdão, e deve procurar garantir a segurança e o apoio mútuo.

Artigo 18: O planejamento familiar sensato é responsabilidade de todo o casal. O relacionamento entre os pais e os filhos deve refletir amor, respeito, estima e a consideração mútuos. Nenhum genitor ou qualquer outro adulto deve explorar, maltratar ou abusar de uma criança. ${ }^{317}$

A sexta e última seção da Declaração, denominada "Conclusão", é formada por um artigo que assim determina:

Artigo 19: Nada nesta Declaração pode ser interpretado como concedendo a qualquer Estado, grupo ou indivíduo o direito de se dedicar a qualquer atividade ou realizar qualquer ato com vistas à destruição de qualquer das responsabilidades, direitos e liberdades apresentados nesta Declaração e na Declaração dos Direitos Humanos de $1948 .{ }^{318}$

\footnotetext{
${ }^{317}$ Seção "Respeito Mútuo e Parceria" da Declaração de Responsabilidades Humanas, publicada em $1^{\circ}$ de setembro de 1997 pelo InterAction Council.

318 Seção "Conclusão" da Declaração de Responsabilidades Humanas, publicada em $1^{\circ}$ de setembro de 1997 pelo InterAction Council.
} 


\section{Conclusão}

Com base no estudo realizado durante o processo de elaboração desta monografia, é possível concluir que:

1) O projeto de Küng tem por principal objetivo garantir uma ordem global pacífica, e consiste na promoção de uma ética mundial básica, composta por princípios mínimos, compartilhados por todas as culturas e definidos por meio de um diálogo intercultural e inter-religioso amplo e constante;

2) O projeto de Küng parte da premissa de que é possível alcançar, por meio de um diálogo intercultural, um consenso global a respeito de princípios éticos que devem ser observados por todos. Assim, a proposta de Küng é metodológica construtivista, no sentido de que apresenta o método pelo qual deverão ser encontrados estes princípios mínimos compartilhados. Dessa assertiva, conclui-se que a ética de Küng pressupõe que: a) um diálogo intercultural é viável; b) existem princípios éticos compartilhados por todas as culturas; c) é possível extrair, de um diálogo intercultural, uma ética prescritiva universal.

2.a) a viabilidade do diálogo intercultural, para o autor, depende da adoção das seguintes posturas por parte dos interlocutores: a) postura de tolerância em relação às outras crenças; b) postura de sensibilidade em relação aos preceitos das demais visões de mundo; c) postura de busca por uma convergência em face de todas as contradições e antagonismos confessionais; d) postura totalmente aberta ao diálogo; e) postura autocrítica em relação às próprias visões de mundo. Não obstante, a factibilidade de diálogo entre representantes de todas as culturas, para Küng, já foi confirmada em diversas ocasiões, dentre as quais merecem destaque: a) o Parlamento das Religiões do Mundo, realizado em Chicago em 1993, no qual se elaborou a Declaração do Parlamento das Religiões do Mundo; e b) o encontro 
promovido em 1997 pela InterAction Council, no qual se discutiu o conteúdo da Declaração Universal das Responsabilidades Humanas;

2.b) a existência de princípios éticos compartilhados por todos os indivíduos, para Küng, pode ser constatada por meio do estudo empírico realizado pelo relativista Michael Walzer na obra Tick and Thin, no qual se comprova que algumas normas morais são reproduzidas em todas as culturas;

2.c) a ética mundial defendida por Hans Küng, em que pese o fato de ser embasada em princípios mínimos compartilhados por todas as culturas, traduz-se em uma ética prescritiva, visto que extraída de um diálogo crítico sobre tudo aquilo que deve ser posto em prática (plano do dever ser) pelas mais diversas culturas.

3) Os principais protagonistas deste processo de busca pelo ethos mundial devem ser:

3.a) os líderes religiosos, uma vez que: 3.a.1) as religiões são elementos fundamentais para uma ordem mundial pacífica; 3.a.2) as religiões teriam capacidade especial de mobilização das pessoas em busca de uma ética mundial; 3.a.3) os religiosos têm predisposição para cumprir éticas prescritivas; 3.b) os líderes políticos, visto que: a política tem relevante influência no que diz respeito à manutenção de uma ordem mundial pacífica, e tanto a realpolitik quanto a política idealista já se mostraram incapazes de sustentar a paz global; 3.c) os economistas, uma vez que: no âmbito da economia, também já ficou evidenciada a necessidade de uma via alternativa para: 3.c.1) a separação total entre políticas econômicas e ética, a qual leva a um libertinismo grosseiro e a um capitalismo desenfreado, causadores de uma ordem social 
extremamente desigual e injusta; 3.c.2) a economia moralista, que, ao preocupar-se apenas com as intenções dos agentes, e não com os resultados de suas condutas, demonstrou-se ineficiente.

4) o método proposto por Hans Küng já foi utilizado em duas experiências concretas, das quais é possível extrair esboços de um ethos mundial da humanidade:

4.a) a Declaração do Parlamento das Religiões Mundiais, elaborada em 1993 pelo Parlamento das Religiões do Mundo, na qual foram relacionadas quatro normas prescritivas, que devem ser seguidas por todas as religiões: a ordem "Não matarás!", da qual decorre um compromisso com a cultura da não violência"; a ordem "Não roubarás!", da qual decorre o compromisso com uma cultura da solidariedade e uma ordem econômica justa; a ordem "Não mentirás!", da qual decorre o compromisso com uma cultura da tolerância e uma vida de veracidade, e a ordem "Respeitai e amai os outros!", da qual decorre o compromisso com uma cultura de igualdade direitos e de companheirismo entre homem e mulher;

4.b) A Declaração de Responsabilidades Humanas, elaborada em 1997 pelo InterAction Council, na qual foram relacionados deveres que devem ser cumpridos por todo e qualquer indivíduo: a) o dever de tratar todas as pessoas de maneira humana; b) o dever de lutar para que todos tenham liberdade e dignidade; c) o dever de promover o bem e de evitar o mal em todas as ocasiões; d) o dever de não fazer aos outros o que não deseja que outros lhe façam; e) o dever de respeitar a vida, traduzido no combate a atos que agridam, torturem ou matem outras pessoas; f) o dever de buscar resolver os conflitos de forma pacífica; g) o dever de 
conscientizar-se ecologicamente e de proteger a natureza; h) o dever de portar-se com integridade, honestidade e justiça; i) o dever de esforçar-se para erradicar problemas sociais como a pobreza, a desnutrição, a ignorância, a desigualdade; j) o dever de buscar uma ordem econômica e social justa; k) o dever de falar e agir de forma honesta - ainda que ninguém esteja obrigado a ser sincero o tempo todo; 1) o dever de respeitar a privacidade e o sigilo pessoal e profissional; $\mathrm{m}$ ) o dever de seguir padrões éticos gerais no exercício da profissão, seja esta qual for; $\mathrm{n}$ ) o dever dos meios de comunicação de prestar informações verdadeiras, de forma responsável e discreta; o) o dever, em especial dos líderes religiosos, de combater manifestações de preconceito e atos de discriminação contra as pessoas de crenças diferentes, incitações ao ódio, ao fanatismo e às guerras religiosas; p) o dever de promover a tolerância e o respeito mútuo entre todos os indivíduos; q) o dever de agir com respeito, compreensão, solidariedade, lealdade e amor nos relacionamentos amorosos e nos relacionamentos familiares; r) o dever de preocupar-se com o planejamento familiar.

Vale acrescentar que se manifestaram a favor do projeto de ética mundial de Hans Küng influentes intelectuais, políticos e religiosos, tais como Richard von Weizsäcker, presidente da República Federativa da Alemanha de 1984 a 1994; Mary Robinson, primeira presidente mulher da Irlanda (1990-1997) e Alta Comissária das Nações Unidas para os Direitos Humanos de 1997 a 2002; Martti Oiva Kalevi Ahtisaari, presidente da Finlândia de 1994 a 2000, agraciado com o Prémio Nobel da Paz em 2008; Juan Somavía, advogado e diplomata chileno eleito em 1999 como DiretorGeral da Organização Internacional do Trabalho (OIT); Rigoberta Menchú Tum, indígena guatemalteca do grupo Quiché-Maia agraciada com o Nobel 
da Paz de 1992, Embaixadora da Boa-Vontade da UNESCO e vencedora do Prêmio Príncipe das Astúrias de Cooperação Internacional; Theodor "Teddy" Kollek, prefeito de Jerusalém entre os anos de 1965 e 1993; Rabbi Professor Jonathan David Magonet, teólogo e escritor judeu, vicepresidente da União Mundial do Judaísmo Progressista e Diretor da Faculdade de Leo Baeck; René-Samuel Sirat, Vice-Presidente da Conferência Europeia de Rabinos; Franz König, Arcebispo de Viena de 1956 até 1985 e um dos principais teólogos do Concílio Vaticano II; Konrad Raiser, ex-presidente do Conselho Mundial das Igrejas; Desmond Mpilo Tutu, arcebispo da Igreja Anglicana consagrado com o Prêmio Nobel da Paz em 1984; Hassan Bin Talal, príncipe da Jordânia; Abū Ḥāmid Muḥammad ibn Muḥammad al-Ghazālī, teólogo islâmico, jurista, filósofo, cosmólogo, psicólogo e místico de origem persa, célebre estudioso da história do pensamento islâmico sunita; Mahmoud Hamdi Zakzouk, acadêmico e político, Ministro de Assuntos Religiosos do Egito de 1995 a 2011; Hayime Nakamura, professor da Universidade de Tokio e um dos mais importantes historiadores do budismo, entre outros. ${ }^{319}$

Em razão do exposto, constata-se que Küng, renomado teólogo cristão, sem renunciar à sua religiosidade, demonstra sincera preocupação com a construção de uma ética voltada para a sociedade secular, pluralista e globalizada dos dias de hoje. Seu projeto de ethos mundial, cuja importância é notadamente reconhecida em âmbito internacional, objetiva,

\footnotetext{
${ }^{319}$ As manifestações destes influentes intelectuais, políticos e religiosos a favor do projeto de ética mundial de Hans Küng encontram-se na obra KÜNG, Hans (ed). Reivindicación de una ética mundial. Madrid: Editorial Trotta, 2002. 237 p. De outro lado, cumpre acrescentar que alguns autores manifestaram críticas negativas ao projeto de ética mundial de Küng sob a alegação de que a proposta do teólogo se revestia de caráter utópico. Sobre as críticas, ver VALADIER, Paul. Os limites de uma ética planetária. In: UNISINOS, Revista do Instituto Humanitas Unisinos, edição 240, 2007. p. 9-11. Disponível em: <http://pt.scribd.com/doc/7991717/6/Hans-Kung\%E2\%80\%93-Biografia>. Acesso em: 23 de agosto de 2014, às 23:02; 3) RAZTINGER, Joseph. O que mantém o mundo unido: Fundamentos morais pré-políticos de um Estado liberal. In: HABERMAS, Jürgen; RATZINGER, Joseph. Dialética da Secularização. Florian Schuller (org.). 1. ed. Editora Idéias \& Letras, 2005; SPAEMANN, Robert. Weltethos als Projekt. In: Merkur. Deutsche Zeitschrift für europäisches Denken. n. 570/71, p. 893-904, set./out. 1996.
} 
em última instância, guardar a vida humana, pois, nas palavras de Küng, "não haverá sobrevivência humana sem uma ética mundial". ${ }^{320}$

${ }^{320}$ KÜNG, Hans. Projeto de Ética Mundial - Uma moral ecumênica em vista da sobrevivência humana. 4. ed. São Paulo: Paulinas, 2003. p. 7. 


\section{Referências Bibliográficas}

BOSTON COLLABORATIVE ENCYCLOPEDIA OF WESTERN THEOLOGY. World Parliament of Religions (1893). Disponível em: <http://people.bu.edu/wwildman/bce/worldparliamentofreligions1893.htm> . Acesso em: 20 de agosto de 2014.

CARRACEDO, José Rubio. Ética constructivista y autonomía personal. Madrid: Tecnos, 1992. 312 p.

CIOTOLA, Marcello Raposo. Relativismo, Universalismo e Justiça Distributiva: um estudo sobre a teoria da igualdade complexa e a teoria da justiça como imparcialidade. Rio de Janeiro. 2005. 255 p. Tese de Doutorado em Filosofia do Direito - Departamento de Direito da PUC-Rio. <Disponível em: http://www.maxwell.vrac.pucrio.br/Busca_etds.php?strSecao=resultado\&nrSeq=6220@1>. Acesso em: 09 de outubro de 2014.

CORTINA, Adela. Etica Mínima. 1. ed. São Paulo: Editora Martins Fontes, 2009. $304 \mathrm{p}$.

FRÜHBAUER, Johannes. Da Declaração das Religiões à Declaração dos Estadistas - Estágios na composição da Declaração sobre Responsabilidades Humanas. In: KÜNG, Hans; SCHMIDT, Helmut. Uma ética mundial e responsabilidades globais: duas declarações. São Paulo: Loyola, 2001. 154 p.

HOEREN, Jürgen; KÜNG, Hans. Para que um Ethos Mundial?: Religião e ética em tempos de globalização - conversando com Jürgen Hoeren. São Paulo: Edições Loyola, 2005. 190 p.

INTERACTION COUNCIL. Declaração de Responsabilidades Humanas, publicada em $1^{\circ}$ de setembro de 1997. In: KÜNG, Hans; SCHMIDT, Helmut. Uma ética mundial e responsabilidades globais: duas declarações. São Paulo: Loyola, 2001. 154 p.

IRWIN, Tirence. The Development of Ethics: A Historical and Critical Study. Volume III. Oxford: Oxford University Press. 1.049 p. 
KANT, Immanuel. Fundamentação da Metafísica dos Costumes. Tradução de Paulo Quintela. 1. ed. Lisboa: EDIÇÕES 70, 2007. 120 p.

KÜNG, Hans. Teologia a Caminho: Fundamentação para o Diálogo Ecumênico. São Paulo: Paulinas, 1999. 300p.

KÜNG, Hans. Uma Ética Global para a Política e a Economia Mundiais. Petrópolis: Editora Vozes, 1999. 475 p.

KÜNG, Hans; SCHMIDT, Helmut. Uma ética mundial e responsabilidades globais: duas declarações. São Paulo: Loyola, 2001.

KÜNG, Hans (ed.). Reivindicación de una ética mundial. Madrid: Editorial Trotta, 2002. $237 \mathrm{p}$.

KÜNG, Hans. Projeto de Ética Mundial: Uma moral ecumênica em vista da sobrevivência humana. 4. ed. São Paulo: Paulinas, 2003.

KÜNG, Hans. Religiões do mundo: Em busca dos pontos comuns. 1. ed. São Paulo: Verus, 2004. 284 p.

KÜNG, Hans; KUSCHEL, Karl-Josef._Ciencia y Ética mundial. 1. ed. Madrid: Editorial Trotta, 2006. 472 p.

KÜNG, Hans. Libertad Conquistada: Memorias. 4. ed. Madrid: Editorial Trotta, 2007. $619 \mathrm{p}$.

KÜNG, Hans. Ética mundial en América Latina. 1. ed. Madrid: Editorial Trotta, 2008. $96 \mathrm{p}$.

KÜNG, Hans. Verdad controvertida. 2. ed. Madrid: Editorial Trotta, 2009. $768 \mathrm{p}$.

KÜNG, Hans. ¿Vida eterna?. $5^{\text {a }}$ ed. Madrid: Editorial Trotta, 2011. 384 p.

KÜNG, Hans. El islam: Historia. Presente. Futuro. 3. ed. Madrid: Editorial Trotta, 2011. $856 \mathrm{p}$. 
KÜNG, Hans. El cristianismo: Esencia e historia. 6. ed. Madrid: Editorial Trotta, 2013. 960 p.

KUNG, Hans. El judaísmo: Pasado, presente y futuro. 7. ed. Madrid: Editorial Trotta, 2013. 720 p.

KUNG, Hans. ¿Tiene salvación la Iglesia?. 1. ed. Madrid: Editorial Trotta, 2013. 200 p.

KUNG, Hans. Humanidad Vivida: Memorias. 1. ed. Madrid: Editorial Trotta, 2014. 768 p.

PARLAMENTO DAS RELIGIÕES DO MUNDO. Declaração do Parlamento das Religiões do Mundo, solenemente proclamada em 4 de setembro de 1993. In: KÜNG, Hans; SCHMIDT, Helmut. Uma ética mundial e responsabilidades globais: duas declarações. São Paulo: Loyola, 2001. 154 p.

RAZTINGER, Joseph. O que mantém o mundo unido: Fundamentos morais pré-políticos de um Estado liberal. In: HABERMAS, Jürgen; RATZINGER, Joseph. Dialética da Secularização. Florian Schuller (org.). 1. ed. São Paulo: Editora Idéias \& Letras, 2005. 104 p.

SANTABARBARA, Luis González-Carvajal. Los cristianos en un Estado Laico. Madrid: Editora PPC, 2008. 159 p.

STRUCHINER, Noel. O direito como um campo de escolhas: por uma leitura das regras prescritivas como relações. In: BARBOSA, Samuel Rodrigues; DA SILVA E COSTA, Carlos Eduardo Batalha; RODRIGUEZ, José Rodrigo (Orgs). Nas Fronteiras do Formalismo: A Função Social da Dogmática Jurídica Hoje. São Paulo: Editora Saraiva, 2010. 384 p.

The World Bank. World Parliament of Religions. Disponível em: <http://web.worldbank.org/WBSITE/EXTERNAL/EXTABOUTUS/PART NERS/EXTDEVDIALOGUE/0,,contentMDK:20270092 menuPK:147728 1 pagePK:64192523 piPK:64192458 theSitePK:537298,00.html>. Acesso em: 20 de agosto de 2014. 
UNISINOS, Revista do Instituto Humanitas Unisinos, edição 240, 2007. p. 3. Disponível em: <http://pt.scribd.com/doc/7991717/6/Hans-Kung\%E2\%80\%93-Biografia>. Acesso em: 23 de agosto de 2014.

WALZER, Michael. Moralidad en el Ámbito Local e Internacional. Tradução de Rafael Del Águila. Madrid: Alianza, 1996. 137 p. 